\title{
An Archaeological and Historical Assessment of the Vista Verde South Project, San Antonio, Texas
}

Joseph H. Labadie

Follow this and additional works at: https://scholarworks.sfasu.edu/ita

Part of the American Material Culture Commons, Archaeological Anthropology Commons, Environmental Studies Commons, Other American Studies Commons, Other Arts and Humanities Commons, Other History of Art, Architecture, and Archaeology Commons, and the United States History Commons

Tell us how this article helped you.

This Article is brought to you for free and open access by the Center for Regional Heritage Research at SFA ScholarWorks. It has been accepted for inclusion in Index of Texas Archaeology: Open Access Gray Literature from the Lone Star State by an authorized editor of SFA ScholarWorks. For more information, please contact cdsscholarworks@sfasu.edu. 
An Archaeological and Historical Assessment of the Vista Verde South Project, San Antonio, Texas

\section{Creative Commons License}

\section{(c) (1) (8)}

This work is licensed under a Creative Commons Attribution-NonCommercial 4.0 International License 


\section{AN ARCHAFOLOGLAL AND IISTORIOAL ASSIESSMENT OF THE VISTA VERDE SOUWH DROJECI, SAN ANTONIO, TEXAS}

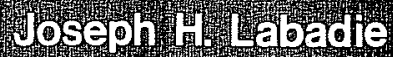

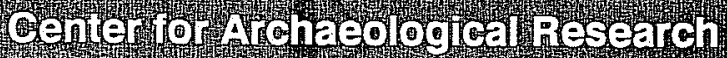

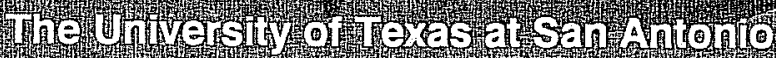

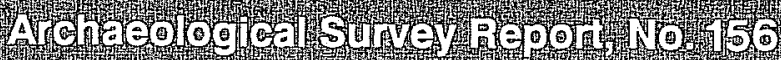





\section{AN ARCHAEOLOGICAL AND HISTORICAL ASSESSMENT OF THE VISTA VERDE SOUTH PROJECT, SAN ANTONIO, TEXAS}

Joseph H. Labadie

Center for Archaeological Research The University of Texas at San Antonio ${ }^{\circledR}$ Archaeological Survey Report, No. 156 



\begin{abstract}
The Vista Verde South project area has borne witness to much of the economic development that has occurred in downtown San Antonio since the early years of Texas' statehood. As with many other areas of San Antonio, economic interests stimulated early development. Following the Civil War, this area became an integral part in San Antonio's flourishing freight hauling and transportation network. By the turn of the 20th century, the area had developed into an ethnically diverse, middle-class neighborhood, while just a few blocks away, San Antonio's infamous Red Light District thrived. The Great Depression of 1929 struck a critical blow to economic development of this area from which it never fully recovered. Economic decline and social change reduced this neighborhood to a "blighted area" within a sprawling metropolitan city by the 1970s. The purpose of the Vista Verde South project is to revitalize 31 city blocks by redevelopment. This report documents the historical, architectural, and archaeological remnants left from roughly 150 years of known occupation in the project area.
\end{abstract}




\section{TABLE OF CONTENTS}

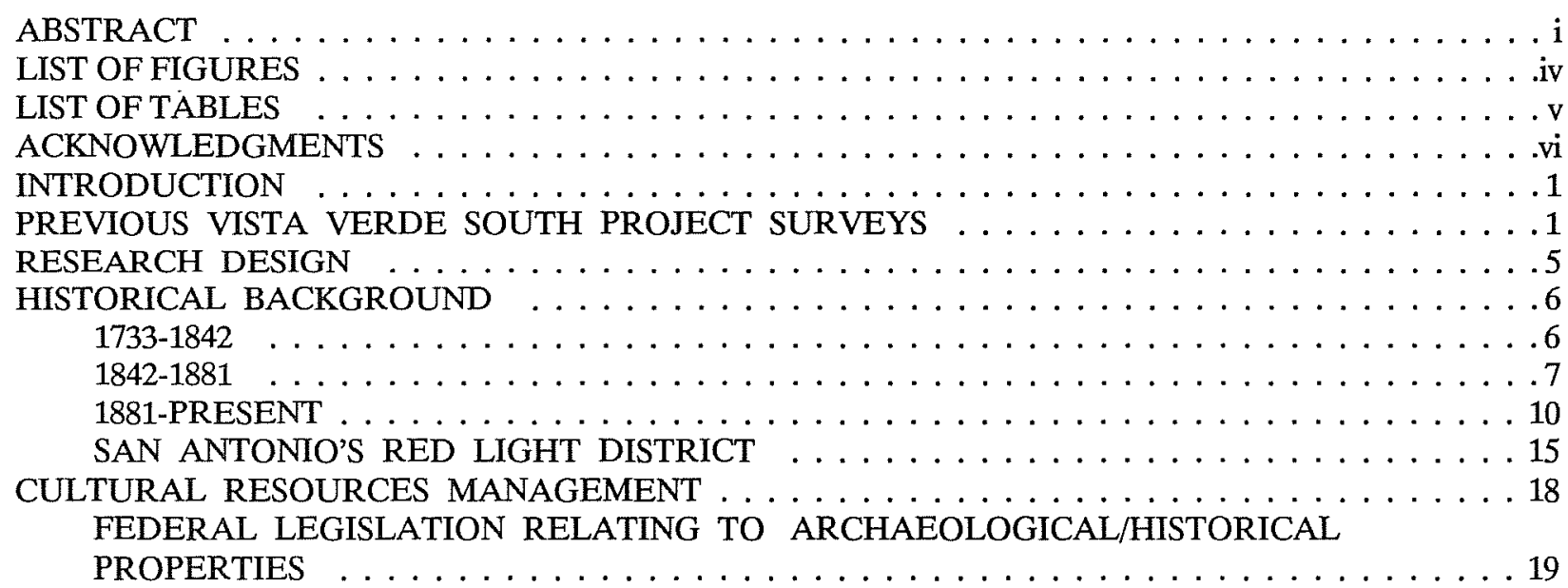

SIGNIFICANCE OF A PROPERTY/SITE . . . . . . . . . . . . . . . . . . . . . 19

NATIONAL REGISTER ELIGIBLE PROPERTIES WITHIN THE VISTA VERDE SOUTH

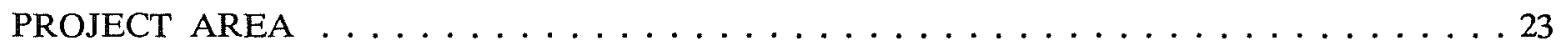

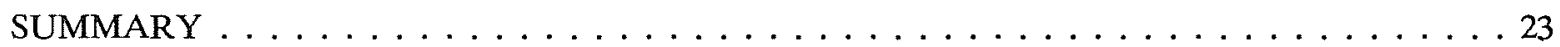

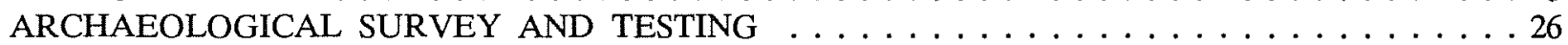

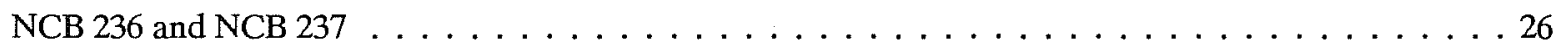

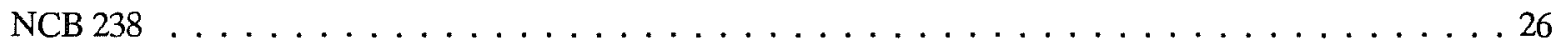

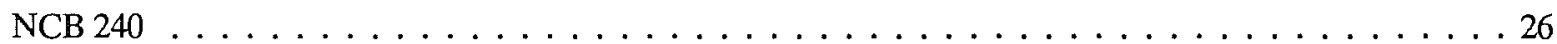

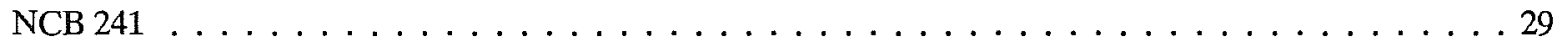

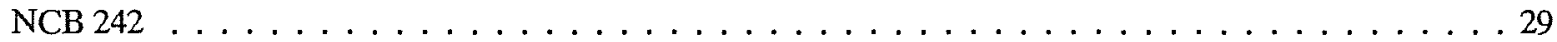

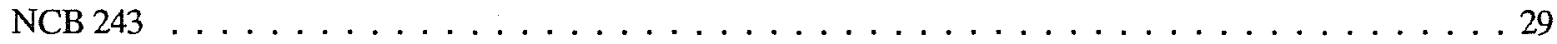

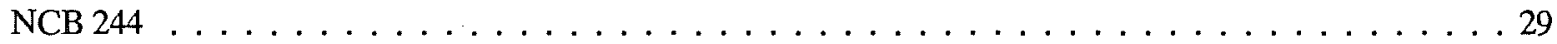

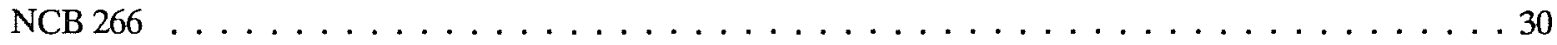

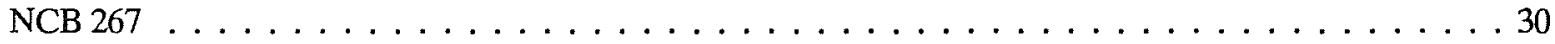

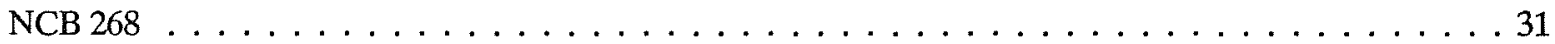

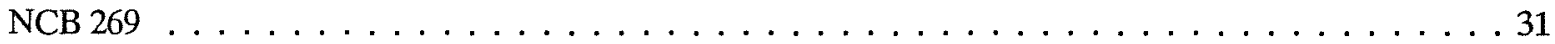

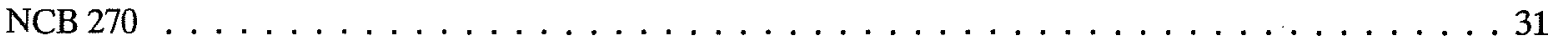

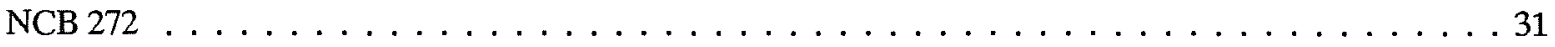

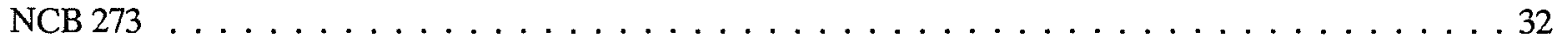

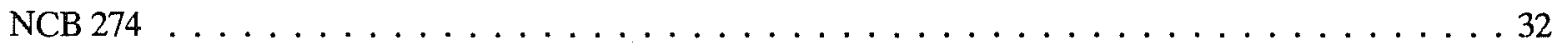

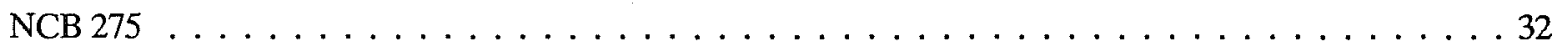

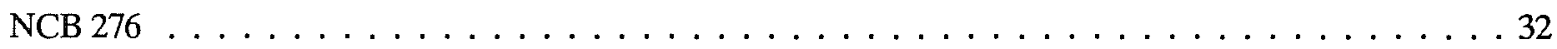

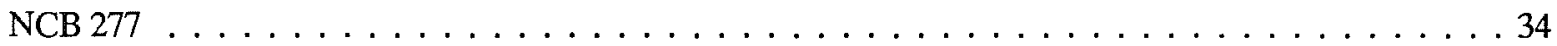

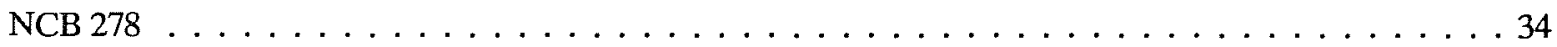

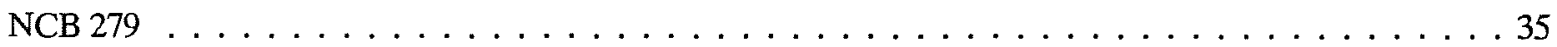

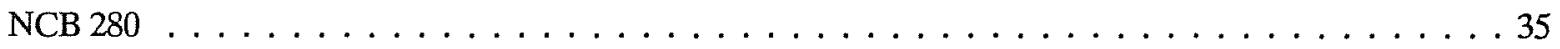

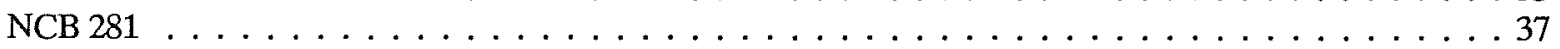

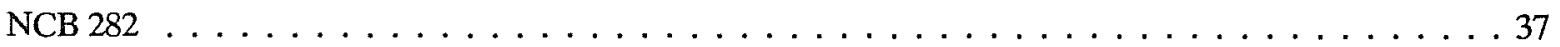

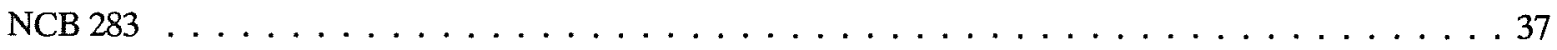

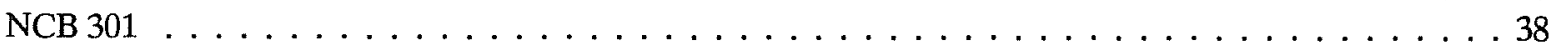

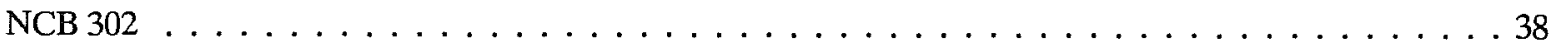

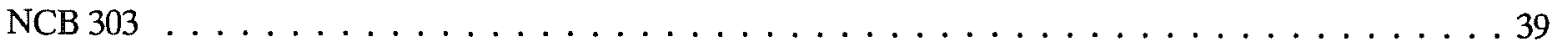

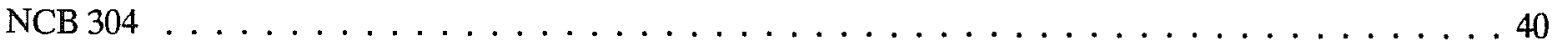

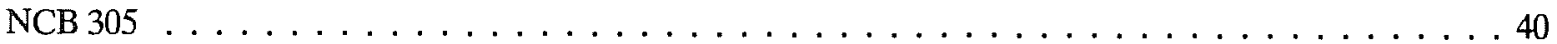

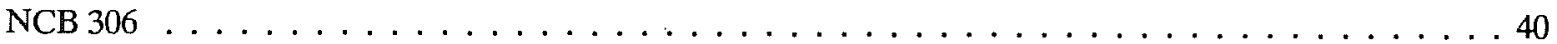

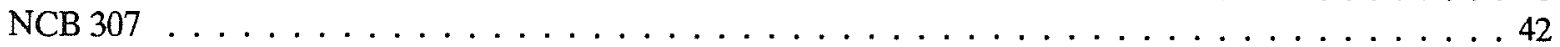

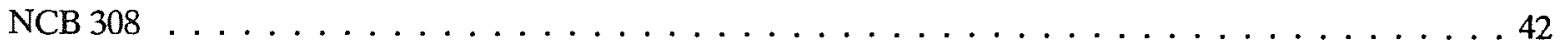

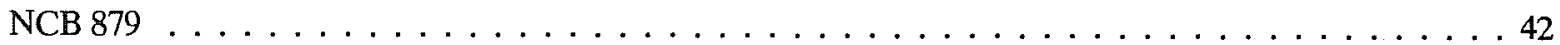




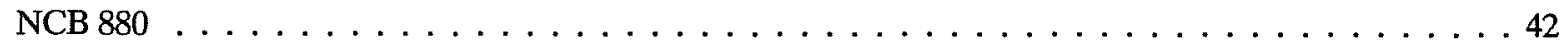

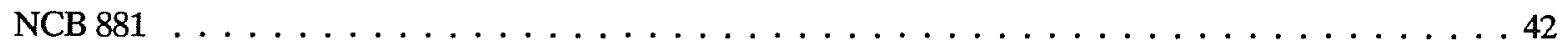

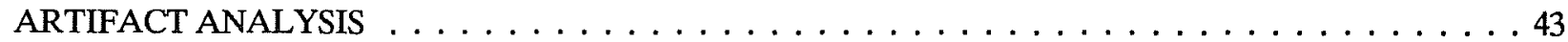

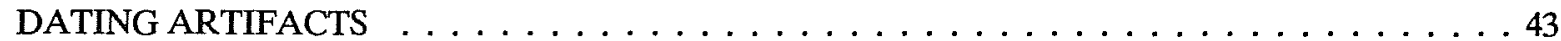

RECOVERED ARTIFACTS $\ldots \ldots \ldots \ldots \ldots \ldots \ldots \ldots \ldots \ldots \ldots$

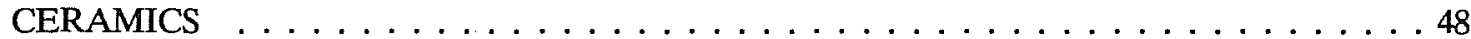

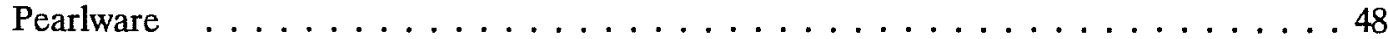

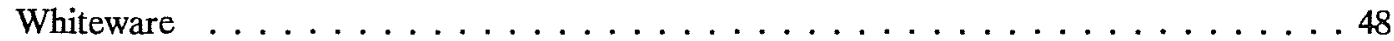

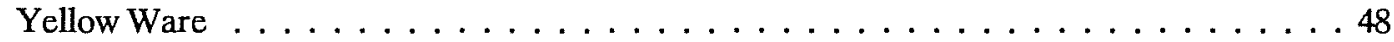

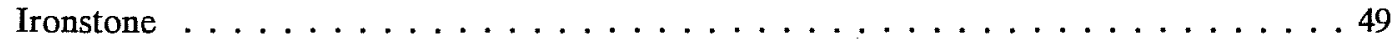

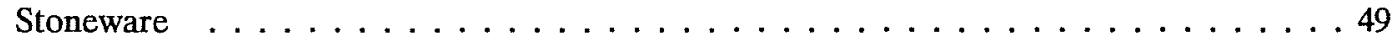

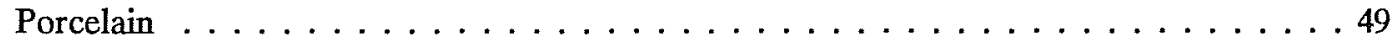

Mexican Lead-Glazed Ware $\ldots \ldots \ldots \ldots \ldots$. . . . . . . . . . . . . . . . . . . . . . . . . . . . .

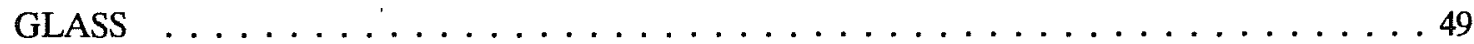

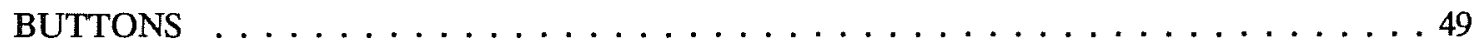

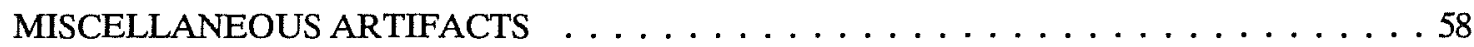

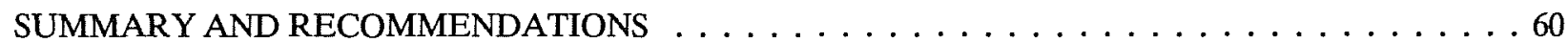

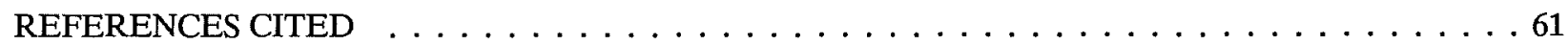

APPENDIX: STRUCTURES IN THE VISTA VERDE SOUTH PROJECT AREA . . . . . . . . . 68 


\section{LIST OF FIGURES}

1. Location of the Vista Verde South Project Area in San Antonio . . . . . . . . . . . . . 2

2. The Vista Verde South Project Area . . . . . . . . . . . . . . . . . . . . . . .3

3. Priority 1 Structures From the Breig and Associate (1981) Architectural Survey of the Vista

Verde South Project Area $\ldots \ldots \ldots \ldots \ldots \ldots \ldots \ldots \ldots \ldots \ldots$

4. Copy of Francois Giraud's Map, "Plat of Lands West of San Pedro Creek" Dated 1849 . . . . . . . . .8

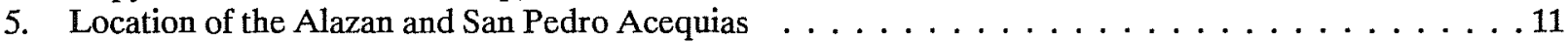

6. A Portion of the Alazan Acequia Beneath South Frio Street . . . . . . . . . . . . . . . . 12

7. Commercial and Residential Structures Depicted in the 1886 Bird's Eye View Map of San Antonio . 13

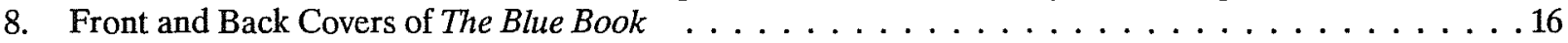

9. Location of San Antonio's Red Light District of $1911 \ldots \ldots \ldots \ldots \ldots \ldots$

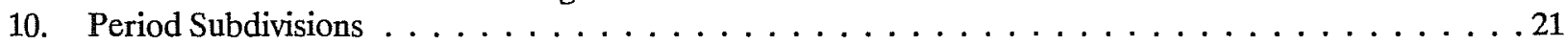

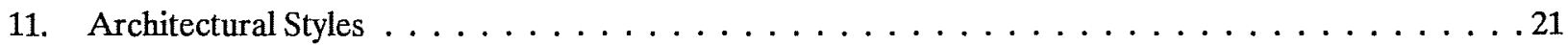

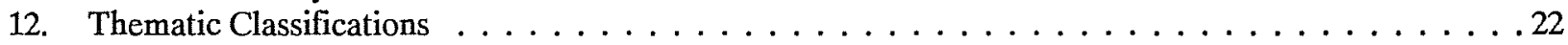

13. Period, Theme, and Architectural Style Classifications for Vista Verde South Project Properties

That Have Been Determined Eligible for Nomination to the National Register of Historic Places . . 22

14. Site Location of Historic Structures in the Vista Verde South Project Area That Have Been

Determined Eligible for Nomination to the National Register of Historic Places . . . . . . . . . . . 24

15. National Register Eligible Properties Which Have Been Destroyed by Vista Verde South Project

Development . . . . . . . . . . . . . . . . . . . . . . 25

16. NCB Designations Within the Vista Verde South Project . . . . . . . . . . . . . . . . 27

17. Location of City Blocks Surveyed and the Percentage of Each Block Accessible to Survey . . . . . . 28

18. Location of Shovel Tests Behind 908 South Frio Street, NCB $276 \ldots \ldots \ldots$. . . . . . . . . . 33

19. Composite Soil Profile for Shovel Tests $1-5$, NCB $276 \ldots \ldots \ldots \ldots \ldots$

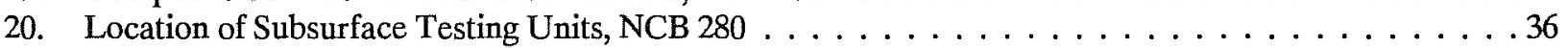

21. Composite Soil Profile for Shovel Tests $1-4$, NCB $280 \ldots \ldots \ldots \ldots$

22. Location of Subsurface Test Units on NCB $303 \ldots \ldots \ldots \ldots$

23. Jose Antonio Navarro School Complex on NCB $305 \ldots \ldots \ldots \ldots \ldots \ldots$

24. Estimating Age of Glass Containers Using Mold Seams . . . . . . . . . . . . . . . . . . . 45

25. Glass Container Rims and Necks With Known Historical Functions . . . . . . . . . . . . . . 46

26. 19th-Century Household Ceramic Fragments . . . . . . . . . . . . . . . . . . 51

27. 19th-Century and 20th-Century Buttons and Household Ceramics . . . . . . . . . . . .53

28. Late 19th-Century Bottles and Bottle Necks . . . . . . . . . . . . . . . . . . . 55

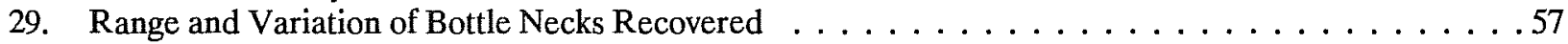

30. Miscellaneous Artifacts . . . . . . . . . . . . . . . . . . . . . . . .59

31. Structures at 602 Buena Vista Street and 301-315 South Frio Street . . . . . . . . . . . . . . 69

32. Structures at 323 South Frio Street and 427-441 South Frio Street . . . . . . . . . . . . . . . . . 70

33. Structures at 701 South Leona Street and 514 South Frio Street . . . . . . . . . . . . . . . .71

34. Structures at 508 South Frio Street and 208 South Leona Street $\ldots \ldots \ldots \ldots \ldots \ldots \ldots$

35. Structures at 209 South Pecos Street and 211 South Pecos Street $\ldots \ldots \ldots \ldots$. . . . . . . . . . 73

36. Structures at 213 South Pecos Street and 420 Matamoras Street . . . . . . . . . . . . . . . . 74

37. Structures at 416 Matamoras Street and 401 South Pecos Street . . . . . . . . . . . . . . . . . 75

38. Structures at 411 South Pecos Street and 717 South Pecos Street $\ldots \ldots \ldots \ldots$. . . . . . . 76

39. Structures at 721 South Pecos Street and 324 El Paso Street . . . . . . . . . . . . . . . . . . 77

40. Structures at 801 South Pecos Street and 709 South Leona Street . . . . . . . . . . . . . . 78 


\section{LIST OF TABLES}

1. Location of Known Brothels on Matamoras Street in $1911 \ldots \ldots \ldots$. . . . . . . . . . . . . . 18

2. Materials Recovered During the Vista Verde South Project Area Survey . . . . . . . . . . . . 43

3. Dates for Known Historical Changes in Glass Container Manufacture . . . . . . . . . . . . . . 47 


\section{ACKNOWLEDGMENTS}

The completion of this report was aided by the help of many people. The field crew consisted of Ralph Snavely, Margaret Greco, Charles Suhler, Elizabeth Craig, Kathy Gonzalez, Marlene Syverson, and Anne A. Fox, field director. I. Waynne Cox generously shared his previous research on the Red Light District in San Antonio with this author. Deserving of special mention are David Hafernik and Elizabeth Craig. Beth spent many hours behind the camera and in the darkroom preparing the photographs of the artifacts used in this report. David contributed a considerable amount of time preparing various maps for this report. All photographs in the appendix were provided by DeLara-Almond Architects, Inc., of San Antonio.

A special thank you to Anne A. Fox, director of the CAR-UTSA laboratory, who was always available for consultation and advice. Without her help, this report could not have been possible. 


\section{INTRODUCTION}

The Vista Verde South project is financed by an Urban Development Action Grant (UDAG) and has been designed by city planners to economically revitalize roughly 150 acres in downtown San Antonio, Texas (Fig. 1). The cultural resources of the area, including both prehistoric and historic properties, are governed by Section 106, the National Historic Preservation Act of 1966 as amended (16 U.S.C. 470), 36 CFR 800 (Procedures for the Protection of Historic and Cultural Properties), and a Memorandum of Agreement (with amendments) between the Texas Historical Commission (THC) and project developers. This federally funded project, which to date has consisted of nearly 15 years of planning, demolition, and construction, is still far from complete.

The area is located west of San Antonio's present-day downtown central business district and is bounded on the north by Buena Vista Street, on the south by Tampico Street, on the east by South Pecos Street and I.H. 35, and on the west by Alazan Creek and San Marcos Street (Fig. 2). Previous surveys and archival research have attempted to document the architectural and historical resources within the physical boundaries of the project. As a result, over 35 structures of architectural and historical significance were identified and determined eligible for nomination to the National Register of Historic Places. A major shortcoming of the previous research was the failure to identify and/or investigate the historical, architectural, and archaeological resources which may lie beneath the present-day ground surface.

The present survey conducted by the Center for Archaeological Research, The University of Texas at San Antonio (CAR-UTSA) was designed to fill this void in information (City Ordinance 57031, 1983). The survey crew consisted of six graduate anthropology students under the direction of Thomas R. Hester, principal investigator; Jack D. Eaton, coprincipal investigator; and Anne A. Fox, coprincipal investigator and field director. The project area was surveyed by pedestrian reconnaissance survey (Phase I, June 8-13,1983). Specifically targeted properties were then selected for intensive survey and limited testing based on previous published surveys, archival research, and the reconnaissance survey results. The intensive survey (Phase II, June 27-29, 1983) was intended to locate and obtain descriptive and evaluative data for properties that might be of National Register potential. The research design, therefore, was not oriented around any one specific research problem; rather, it was designed to be a comprehensive study of all data recovered. All materials have been inventoried and catalogued, and are curated at the CAR-UTSA facilities.

A major problem could have been avoided by a more timely archaeological survey of the area; many of the residential and commercial structures previously documented had been demolished before the CAR-UTSA investigations. Nearly two years had elapsed between the architectural surveys and the commencement of the CAR-UTSA survey. Large areas, and in some cases entire city blocks, had been cleared of all structures. Subsurface disturbances attributable to bulldozing and ground leveling activities were widespread as well. These physical conditions in the survey area dramatically illustrate the necessity for establishing priorities to deal with San Antonio's remaining historic resources within the framework of existing urban planning programs.

Historical, architectural, and archaeological data have been combined in this report to provide the reader with a detailed picture of roughly 150 years of habitation in the project area. From its earliest days, this area has contributed to the economic, social, cultural, and historical development of San Antonio.

\section{PREVIOUS VISTA VERDE SOUTH PROJECT SURVEYS}

The exact number of intact structures within the Vista Verde South project at any one period cannot be confidently established. A conservative estimate would be in the range of 300 at the start of the Vista Verde South project demolition operations in 1981.

An architectural survey by Breig and Associate was designed to record only those structures "historically significant." In the Breig and Associate (1981:1) report, the structures are classified into three categories: residential, commercial, and civic. Structures within these categories are individually rated as to priority $(1,2$, or 3$)$. The author(s) do not explain the basis for these priority assignations; they do not appear to be related to the historical 


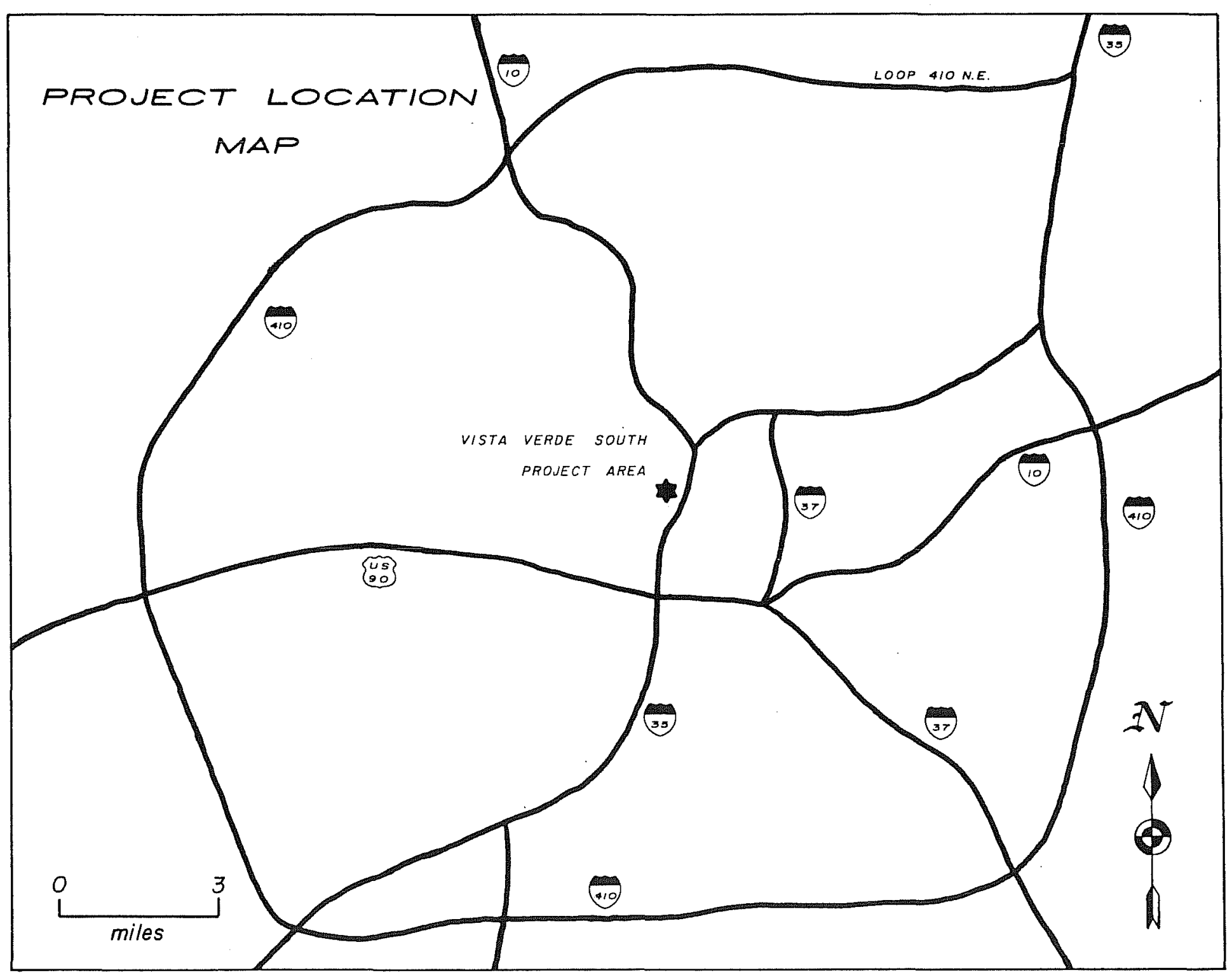

ป્ર

Figure 1. Location of the Vista Verde South Project Area in San Antonio. 


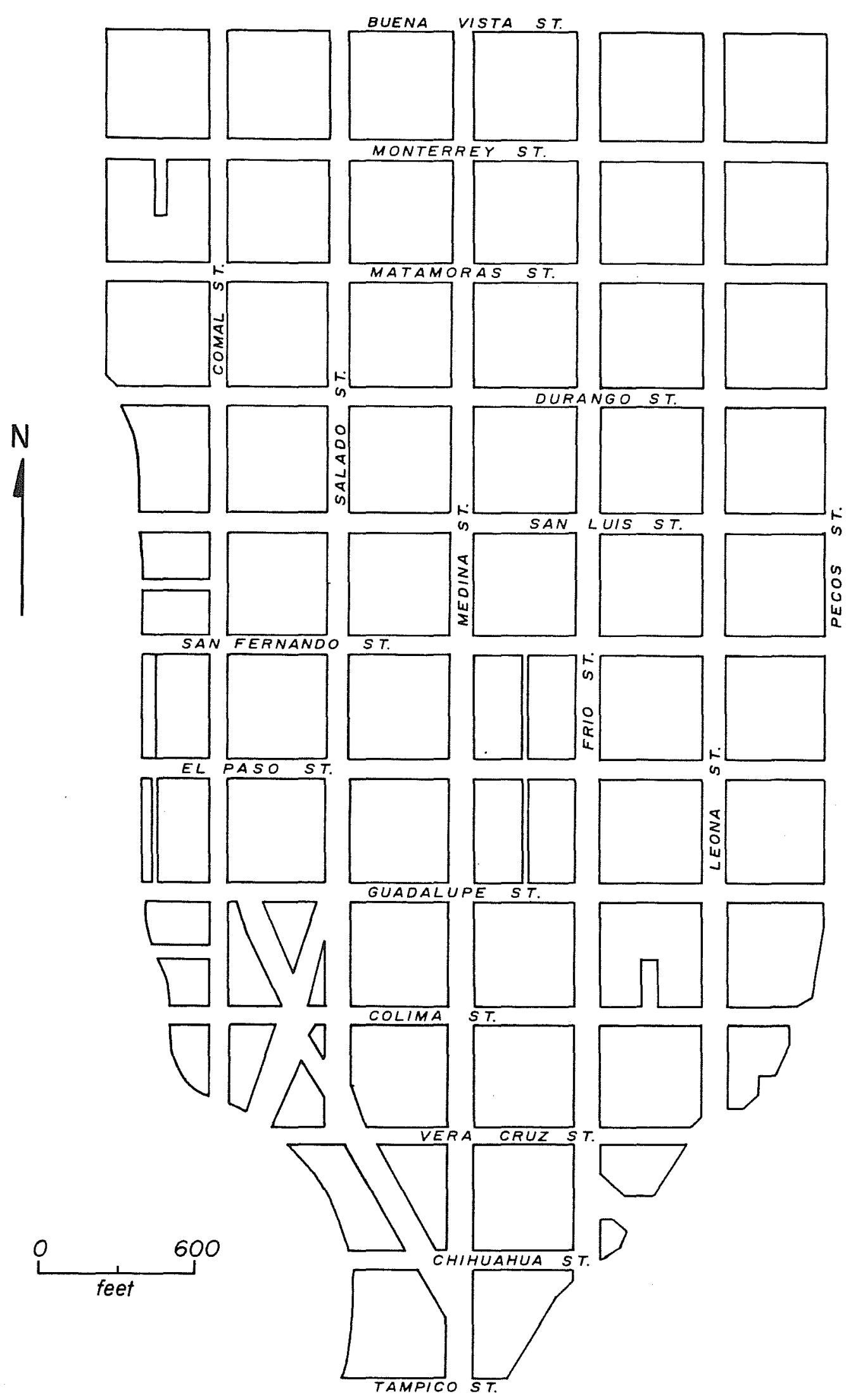

Figure 2. The Vista Verde South Project Area. 
or architectural significance of the property. The report (Breig and Associate 1981) recorded structures and described them using period subdivisions, architectural styles, and themes from the Texas Historical Commission (1979). Figure 3 presents the address and the structural period for all the priority 1 structures. The Breig and Associate survey provides an adequate accounting for some, but not all, of the intact structures at that time within the Vista Verde South project area.

\begin{tabular}{|ll|}
\hline Address & Period \\
\hline 715 South Pecos Street & FDT \\
834 South Pecos Street & VT \\
616 San Fernando Street & VT \\
412 Guadalupe Street & VT \\
310 El Paso Street & RP \\
420 El Paso Street & FDT \\
510 San Luis Street & VT \\
403, 405, 407, 409, 411 San Luis Street & FDT \\
908 San Luis Street & VT \\
917 South Leona Street & VT \\
906 South Leona Street & VT \\
208 South Leona Street & VT \\
407 South Leona Street & FDT \\
616 South Frio Street & FDT \\
604 South Frio Street & FDT \\
709 South Frio Street & VT \\
612 South Frio Street & FDT \\
608 South Frio Street & FDT \\
815 South Leona Street & FDT \\
914 Buena Vista Street & VT \\
918 Buena Vista Street & FDT \\
301 South Pecos Street & VT \\
402 San Fernando Street & VT \\
902 South Medina Street & FDT \\
304 South Frio Street & FDT \\
& FDT \\
\hline & FDT \\
& FDT \\
& \\
\hline
\end{tabular}

Figure 3. Priority 1 Structures From the Breig and Associate (1981) Architectural Survey of the Vista Verde South Project Area. FDT = Texas in the First Decades of the 20th Century (1901-1930); RP = Reconstruction Period (1865-1874); VT = Victorian Texas (1874-1901). Periods were developed by the Texas Historical Commission (1979).

An architectural report (DeLara-Almond Architects, Inc. 1981) of the Vista Verde South properties used the National Register criteria to evaluate existing structures. Their survey results were intended to provide an overview of structural resources within the area. However, the report has several shortcomings: consistency in observations and recording (e.g., the survey of New City Block [NCB] 879 recorded three structures which were "representative of many found on this block," therein not recording each structure as was noted for other NCBs), and all 367 pages are unnumbered which severely detracts from the utility of the report.

Neither of the previous architectural surveys (Breig and Associate 1981; DeLara-Almond Architects, Inc. 1981) attempted to record every structure. By the time the CAR-UTSA began field work in the project area, many of the targeted structures for survey and testing had been demolished. 
The two previous surveys do not agree as to how many of the structures are of historical and/or architectural significance. To date, approximately 37 structures have been determined eligible for nomination to the National Register of Historic Places by the State Historic Preservation Officer (SHPO); 21 are pending final approval to the National Register. The Breig and Associate (1981) survey identified two of the 21 structures, while the DeLaraAlmond Architects, Inc. (1981) survey identified all of them; this disparity may simply be due to different levels of research. Differences in opinion as to what constitutes "significance" are not uncommon in National Register assessments, whether at the local, state, or national level.

The major deficiency in previous Vista Verde South area surveys was the failure to address what may lie beneath the surface. Archival research firmly established the archaeological potential for the area. Failure to assess this potential through controlled archaeological investigations has resulted in the loss of a considerable amount of data relating to 19th-century residential occupation in downtown San Antonio.

\section{RESEARCH DESIGN}

The research design for the field work was not based on recovery in "ideal" conditions. Rather, the field work was directed at what had to be done or could still be done given conditions within the project area. Structural and urban debris (commercial/urban debris and trash which would normally have found its way to local dumps but instead had been discarded on vacant lots) obscured the ground surface on many of the blocks to be surveyed. Other blocks were almost entirely covered by operating businesses or occupied residences; asphalt, concrete, and gravel parking areas were also quite common. Other city blocks had been swept clean of all existing structures by demolition crews, and fill dirt had been used nearly everywhere to level surfaces. For these blocks and portions thereof, the report prepared by DeLara-Almond Architects, Inc. (1981) for the City of San Antonio, combined with the Breig and Associate (1981) report prepared for the San Antonio Conservation Society, became invaluable research tools for describing the conditions of the area before the CAR-UTSA survey team arrived on site.

Before the survey began, numerous reports, histories, and a variety of maps (insurance, city, military, and the 1873 and 1886 bird's eye view maps of San Antonio [Koch 1873, 1886]) were carefully scrutinized for indications of manmade structures such as wells, cisterns, buildings, etc., which might be of archaeological interest. The field survey sought to establish exactly what remnants of the past were still in their primary contexts. Each city block was treated as a separate survey unit and assessed on an individual basis. Structures noted on early maps which might be of historical importance were further researched in the city and county archival records.

Field sampling methods consisted of pedestrian reconnaissance and a limited subsurface testing program. Wherever possible, the entire surface of the block was surveyed. For targeted areas (based on archival research) which appeared to be undisturbed, shovel testing was done to seek evidence of earlier structures and to establish the stratigraphic sequence of subsurface soil and deposits. In targeted areas where the ground appeared to have been disturbed by recent project activities (scraping and bulldozing), random shovel testing sought to establish if structural or cultural remnants remained. For areas that were impossible to survey due to commercial or residential structures or in areas of recent soil fill, the percentage of structural and fill coverage was noted.

The locations for subsurface shovel tests were laid out by line of sight without the use of surveying equipment. Both linear transects and grid-pattern systems were employed to maximize data recovery on soil stratigraphy and cultural deposits. This approach kept the amount of disturbance in the area to a minimum as well as providing a certain amount of flexibility in the survey strategy to meet the variety of conditions present on the various city blocks. Photographic recording and field maps of all shovel test locations were made to assist in the laboratory analysis of recovered materials. 


\section{HISTORICAL BACKGROUND}

The Vista Verde South project area, approximately 150 acres, is a portion of the original land grant by the Spanish Crown (1733) to the settlement Villa de San Fernando (later to be called San Antonio). Historically, little is known about this area from the time of the original Spanish land grant through the early days of the Texas Republic (1840s). The constant threat of Indian depredations had limited the populated sections of early San Antonio to two separate areas: (1) the mission compound and adjacent areas on the east side of the San Antonio River; and (2) the area of the Presidio de Bexar on the west side of the San Antonio River. The Vista Verde South project area is located southwest of the former Presidio de Bexar. Documents from the 18th century indicate that this area was unpopulated, although squatters or residents without legal title to the land could well have occupied some portions.

In 1793, the Viceroy of New Spain issued a decree calling for the abandonment of Mission San Antonio de Valero. With secularization, the role of the mission as a religious institution ended. The mission records were transferred to the San Fernando Church archives, and the mission building complex was officially abandoned.

On December 29, 1802, a Spanish cavalry unit, the Compañia Volante of San Carlos de Parras de Alamo from Chihuahua, was permanently reassigned to San Antonio and occupied the abandoned mission complex (Fox, Bass, and Hester 1976:67). The soldiers that were assigned to the Compañia probably lived in and around the mission complex. A small populated area southwest of the mission became known as the "barrio del Alamo" by about 1807. By 1810, the area south of Commerce Street, along the west side of South Alamo Street, was being referred to as "La Villita." The project area on the west side of the river appears to have been unpopulated during this time.

Beginning in late 1813-early 1814, San Antonio returned to a period of limited tranquillity, following three years of violence, property confiscations (by Juan Bautista Casas in 1811 and Joaquín de Arredondo in 1813), and several political/military administrations (Manuel de Salcedo in 1810, Casas in 1811, Gutiérrez de Lara and Augustus W. Magee in 1812, and Arredondo in 1813). One local 19th-century historian (Corner 1890:80) stated:

...in all this blood the prosperity of San Antonio was drowned. To settlers, it offered no inducements; to most of its former citizens it held out nothing but terror; and it is described as almost entirely abandoned in 1816.

As news of the signing of the Treaty of Cordova (1821) spread, former citizens began to return to San Antonio along with a tide of new immigrants. By 1823, the population was estimated at 5000 (ibid.:81).

General Santa Anna attacked and captured the Alamo in 1836. Santa Anna's army crossed the Rio Grande at Laredo, approaching the city from the west; his three-pronged attack (from the north, east, and west) on the eighth day of the siege climaxed a bloody struggle. The Vista Verde South project area in all probability served Santa Anna as a staging area prior to battle as well as providing wood, water, and forage for his cavalry and horses.

The San Antonio which Juan Seguin reoccupied on June 4, 1836, was a city in ruins. It was practically deserted as many citizens had left the city with Santa Anna's troops. With their departure, possibly 50 people (excluding Texas soldiers) remained in a city that the previous year had sheltered 2400 citizens (Mayer 1976:111). Seguin took office as mayor of San Antonio in January 1841. He found that one of his major tasks was protecting the Mexican population from the "Anglo scum," despite the fact that San Antonio was overwhelmingly Mexican (ibid.:117). The schism between the Anglo (to include non-Mexican, non-Indian Europeans) minority and Mexican majority deepened in 1842, when Seguin fled the city with news of the Vasquez military expedition and its advancement towards San Antonio. After Vasquez laid waste to the city and departed, Seguin again returned to a much depopulated city as many of the Mexican population had departed with Vasquez. The Anglo population was convinced that Seguin had been in collusion with Vasquez, as evidenced by his timely departure before the arrival of hostile troops. Seguin came under such political pressure that he fled the city in fear for his life. With his departure, the San Antonio Mexican population lost a major protector of their interests (Mayer 1976:119). 
The frequency and regularity of hostile engagements (military vs. Indian, settler vs. Indian, Texan vs. Mexican) and pitched battles (at the Medina River in 1813, at San Antonio in 1835, at the Alamo in 1836, and San Jacinto in 1836), combined with the Anglo-Mexican schism, collectively stagnated economic development. The city of San Antonio was incorporated in 1837 by its own act and in 1842 by act of the Congress of the Republic of Texas. These acts of incorporation allowed the city to focus its political energies and paved the way for the economic stability brought by the United States annexation of Texas in 1846.

\section{$1842-1881$}

The impact of statehood on Texas was immediately felt, particularly in San Antonio, as the United States military chose the Alamo as its headquarters for the entire southwest. The Alamo and its associated buildings were made serviceable once again with the famous Alamo facade installed. With the influx of soldiers and new blood, the economic, social, and cultural heritage of the town soon began to change as well.

The 1842 incorporation of San Antonio, among other things, granted the power to the city to sell unimproved real estate located within the city's jurisdictional boundaries. The rapid growth of the city after annexation prompted the City Council to pass an ordinance in 1849 ordering the sale of land, including the land west of San Pedro Creek. This land was surveyed and platted into blocks the same year by Francois Giraud, San Antonio's first city engineer (Fig. 4). The lots were 20 varas $x 60$ varas or 30 varas $x 60$ varas (one vara is approximately 33 inches).

The Vista Verde South project area represents only a portion of this parceled land west of San Pedro Creek. Its evolution as a distinct neighborhood within this larger parceled area was linked to economic development of the area as a whole, but it was not included within the city boundaries until 1856. In that year, the City Council established new city boundaries extending the limits to a square whose sides were three miles north, east, south, and west of the dome of San Fernando Church (Mayer 1976:268). This land was relatively fertile by comparison to other areas within the city limits and was situated between two waterways (San Pedro and Alazan Creeks). The riparian zones along these waterways would have provided, at least in those days, fish and game as well as wood, a commodity nearly as precious as water. The creeks surely would have been used for bathing, washing clothes, and as a source of potable water; bathing in San Pedro Creek was still common in the 1860s, although participants were subject to frequent Indian attacks (Corner 1890; Barnes 1910). The proximity of this land to the early inhabited areas of San Antonio would likewise have made it ideal for pasturage of animals, although the threat of Indian attack would certainly have been the limiting factor in ranging.

In the court transcripts of the case of Lewis and Others vs. The City of San Antonio (the case that decided once and for all that the City did in fact have a right to sell land west of San Pedro Creek), this area is said to have been used for the "quarrying of stone and pasturage" for a considerable time prior to the 1851 court case. The "quarrying of stone" must here be taken to mean that limestone was available, but organized quarrying or commercial operations were not established. In the 1879-1880 city directory, several quarries are listed (Powder House Hill, Salado Quarry, Calaveras, and Chupaderas Creek Quarry); all are either north or east of San Pedro Creek and Alazan Creek (Appler 1879-1880).

During the 1850s, Giraud's map was available for purchase by the citizenry of San Antonio for private development. North-south and east-west streets were established and given numerical designations. The sale of city-owned land $(1849,1852,1853,1855,1859)$ conveyed properties to former politicians (A. Dignowitty, J. M. Devine, O. B. Brackett, G. T. Howard) who, by 1852 , owned nearly $90 \%$ of what is today the Vista Verde South project area. In the following years, these lands were bought and sold, most as unimproved lots, with more intensive economic development occurring after the Civil War.

The 1879-1880 city directory (Appler 1879-1880:Preface) referred to a Mexican town(s) located west of San Pedro Creek and the Alazan Ditch:

It is almost an impossibility to give exact location of the innumerable little cottages built of sticks and reeds, in homely wise and wall'd with sods around, that are scattered indiscriminately over the territory west of the creek [San Pedro], but more especially in the neighborhood of the Alazan. 


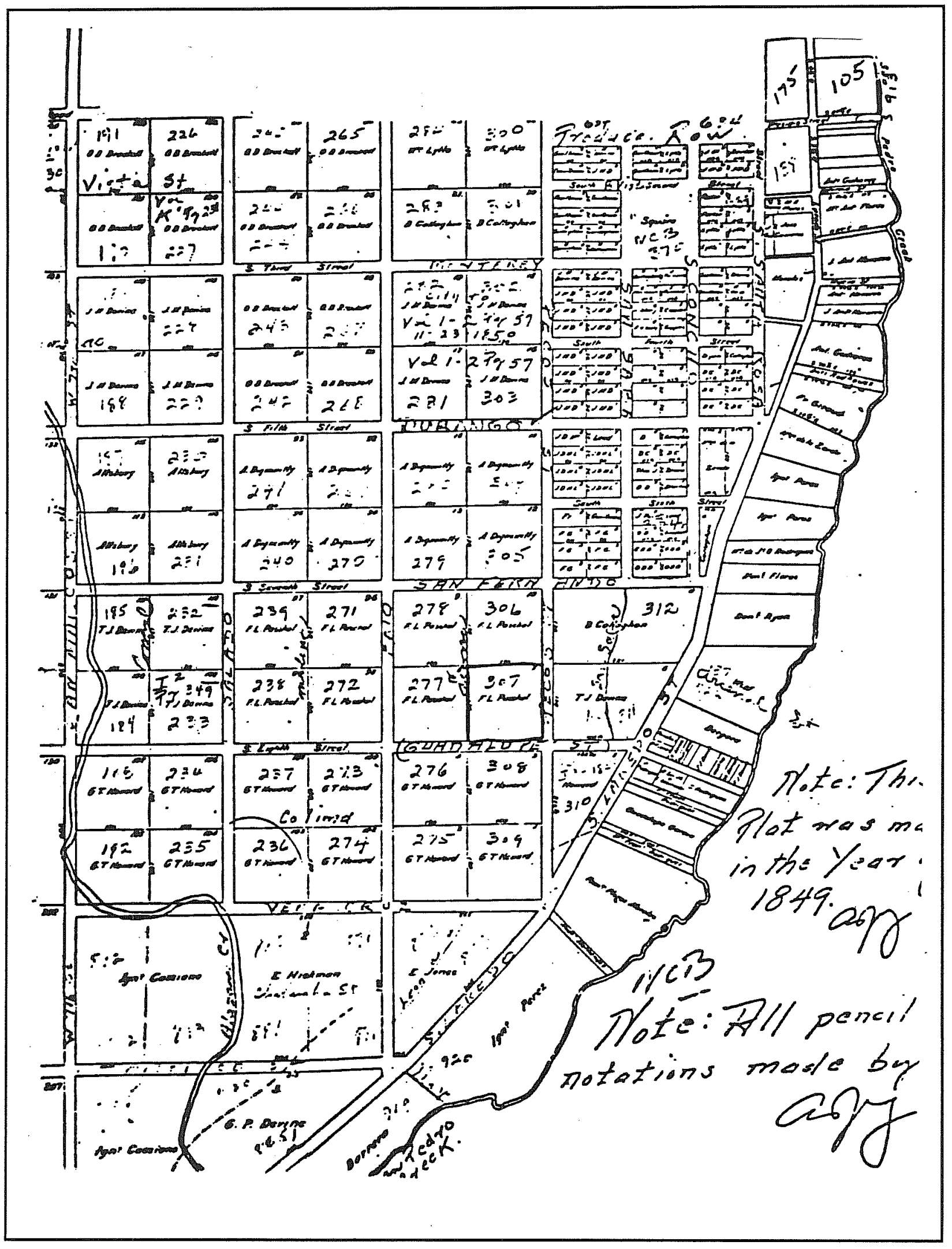

Figure 4. Copy of Francois Giraud's Map, "Plat of Lands West of San Pedro Creek" Dated 1849. From Bobbitt (1981:8). 
It would appear that the Vista Verde South area had, by the late 1870s, become sufficiently populated to warrant inclusion within the city directory (no mention was made in the first city directory [Appler 1877]). However, detail of the area is lacking not because it did not exist, but because of the prejudices of the editors of these publications as the following passage (Appler 1879-1880:Preface) indicates.

There will probably be omissions which are of no material importance, in the Mexican towns, west of the San Pedro Creek and Alazan ditch (the facts and causes of which, many if not all business men are cognizant of) made under instructions of prominent medical adviser.

The foregoing passage or perhaps better stated "disclaimer" for inaccuracies made by the editors is somewhat confusing. The "facts and causes" may refer to the unsanitary conditions related to the Alazan Ditch which had opened in 1875; poor construction and disrepair produced stagnant water; this, combined with trash disposal practices by residents prompted the filling of the ditch in 1890 due to its potential health hazards to the city at large. Cholera epidemics in 1849 and 1852 may also have played a significant part in the writing of this passage.

On the other hand, it is plausible in view of the statement "... omissions which are of no material importance" that the schism between Anglos and Mexicans was still pervasive at this time. This ethnic schism may be responsible for the lack of accurate, detailed information on the barrios west of San Pedro Creek, their population, composition, and businesses.

During the 1850s and prior to the railroad connections to San Antonio (1881), the five or six yoke ox cart (capacity of 3000 pounds) constructed by the Mexicans was the most efficient means of commercial transport; American built carts could carry the same capacity, but required a team of 10-14 mules (Mayer 1976:378). Mexicans proved themselves to be able teamsters, more than capable of competition with Anglos, and by 1850, more than two-thirds of Bexar County's teamsters were Mexican (Mayer 1976:381). By 1857, Mexican teamsters had proved to be more reliable and less expensive which may have sparked the "cart wars" in which many a Mexican teamster died at the hands of jealous Anglo teamsters.

November 12, 1857, John Bowen (San Antonio postmaster and city treasurer) wrote to S. A. Maverick on the conditions west of San Pedro Creek:

San Antonio has no intention of remaining a sleepy Mexican village of sticks and mud jacales and one story flat-roofed adobe huts. While west of San Pedro creek the traditional native construction continued in the Mexican quarter of Laredito and Chichuahua - evidently so named because of the many cartmen who freighted to those cities made their homes there-east of that stream public buildings, business houses, schools, homes, and hotels of Anglo-American and European architectural styles appeared for the first time (Mayer 1976:379-380).

It would seem apparent that part of the Vista Verde South project area represented an enclave of Mexican settlers as early as the 1850s; living in traditional structures, using traditional modes of transportation (yoked ox cart) in business enterprises, and proving themselves more than capable in the flourishing commercial transportation market. It would also seem plausible that the ethnic prejudices of the editors of the first two city directories had produced deliberate omissions of the facts. Considering that the Anglo-Mexican schism may be traced back as early as the 1830s, it is not at all unlikely that some portion of this area had been occupied prior to the 1850s.

Within a few years following the end of the Civil War, most of the lots within the Vista Verde South project area had changed hands several times since their original sale on the docket in the 1850s. Some lots were now in the hands of farmers while most still remained in the possession of land investors and speculators. Agricultural products from this area had been sold to Confederate warehouses during the Civil War with demand exceeding supply.

The Civil War had had a stifling effect on European immigration to San Antonio (via Gulf ports), but when the war was over, the city saw its largest wave of immigrations to date. Ethnic diversity and truck farming quickly began 
replacing the pre-Civil War ethnically homogeneous, service-oriented populace of the area. Ex-Confederate soldiers also played an integral part in the project area's postwar economic expansion, nearly dominating the commercial hauling business in western San Antonio.

Commercial freight hauling had become big business in the project area and in nearby Bracketville to the west, primarily due to the long-established Laredo Highway. Freight was being hauled to points north and west in the frontier and south to Mexico, with Indians being a constant menace no matter which direction wagon trains headed (Indians also had wreaked havoc on Confederate supply trains and severely disrupted supply lines during the war). Freight companies in the late 1860s included Nat Lewis, Sr., and his partners Groesbeck, Edward Froboese, August Santleben, A. Talamantes, Peter Jonas, Henry Bitter, Louis Oge, A. A. Wullf, Charles Guerguin, Jesus Hernandez, William H. Edgar, Anastacio Gonzales, Enoch Jones, H. B. Adams, and his partner E. D. L. Wickes, and a host of others (Barnes 1910:135). By the 1870s, the commercial hauling industry was in its heyday. San Antonio had become the largest wool market in the United States. During one season in the 1870s, two million pounds of wool were sold and shipped in San Antonio (Corner 1890:63).

The largest commercial hauler in the Vista Verde South project area was the company of Adams and Wickes. ExConfederate Majors Hardin B. Adams and E. D. L. Wickes owned a large number of wagons and draft animals and employed several hundred cart men, teamsters, and general laborers (Mayer 1976:573). Their company shipped freight in all directions from San Antonio and seemed to be a favorite target for Indian groups. Twice in 1869, attacks proved to be costly. At Howard Springs, 50 mules were stolen and the driver killed. Near the Devil's River, a wagon train was attacked, the driver escaping only with his life. In 1870, another Adams and Wickes wagon master was killed near Fort Mason (Corner 1890:134, 146). In 1871, Adams and Wickes assured their continued supremacy in the market by contracting with the U.S. Army to provide transportation for government goods to all posts in Texas. By the time the railroad threatened their freight business, the partners owned large and strategically situated properties in the northwest corner of the present-day project area, some of which (NCBs 242, 243, and 244) were sold to the International and Great Northern Railroad. The railroad constructed a depot and support facilities on these properties.

Increased agricultural and residential demands for water west of San Pedro Creek prompted the City Council (1872) to begin work on the Alazan Ditch (Fig. 5). The ditch would pick up water from the Upper Labor Acequia (constructed by the Spanish between 1776-1781) and route this water around the head of San Pedro Springs and into the valley of the Alazan Creek (Bobbitt 1981:20).

The ditch opened June 9,1875 , and was completed by late 1876 , at a cost of $\$ 33,000$ to the city (ibid.). In 1890 , the ditch was filled and forgotten due to the encroaching residential neighborhoods and commercial businesses. Today, much of the Alazan Ditch remains essentially intact beneath South Frio and Tampico Streets (see Fig. 6). With the coming of the railroad (1881) and the closing of the ditch (1890), commercial farming in the project area came to an end.

\section{1-PRESENT}

The International and Great Northern Railroad (I \& GN Railroad) depot opened February 16, 1881, with tracks running through the western edge of the project area roughly paralleling the course of the Alazan Ditch. The 1886 bird's eye view map (Koch 1886) clearly depicts a concentration of commercial structures, warehouses, stockyards, and a depot east of the railroad tracks (see Fig. 7). The I \& GN Railroad had bought six contiguous blocks of property (NCB 242-247) to ensure future growth in an area of the city that was rapidly becoming a residential neighborhood. In 1886, the heaviest residential concentrations were located in the south and eastern portions of the project area (see Fig. 7).

Also in 1881, the City of San Antonio began street repairs in the project area. Streets running east-west were renamed for cities in Mexico. Streets running north-south were later renamed for rivers in Texas (Bobbitt 1981:11). 


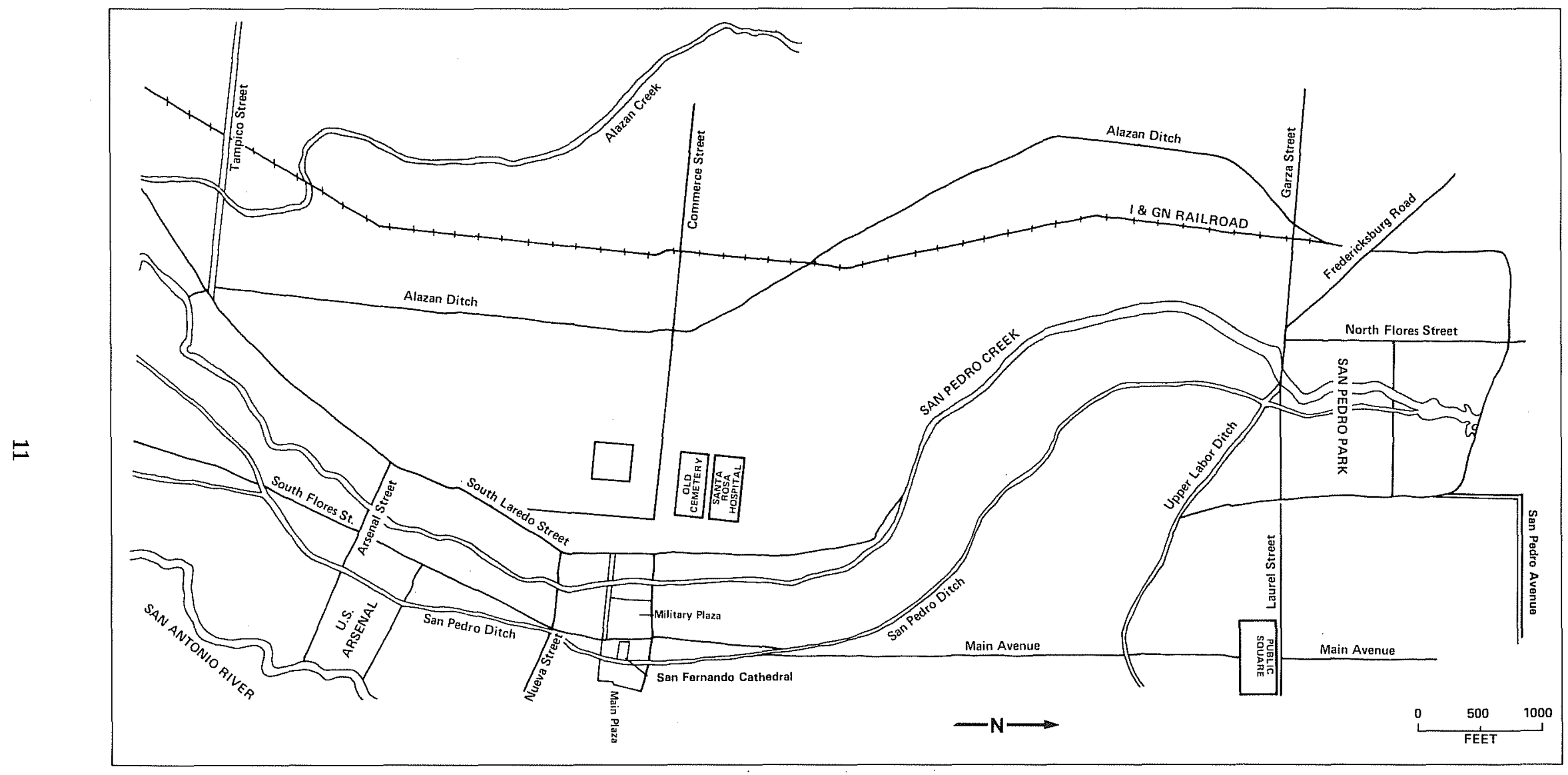

Figure 5. Location of the Alazan and San Pedro Acequias. 


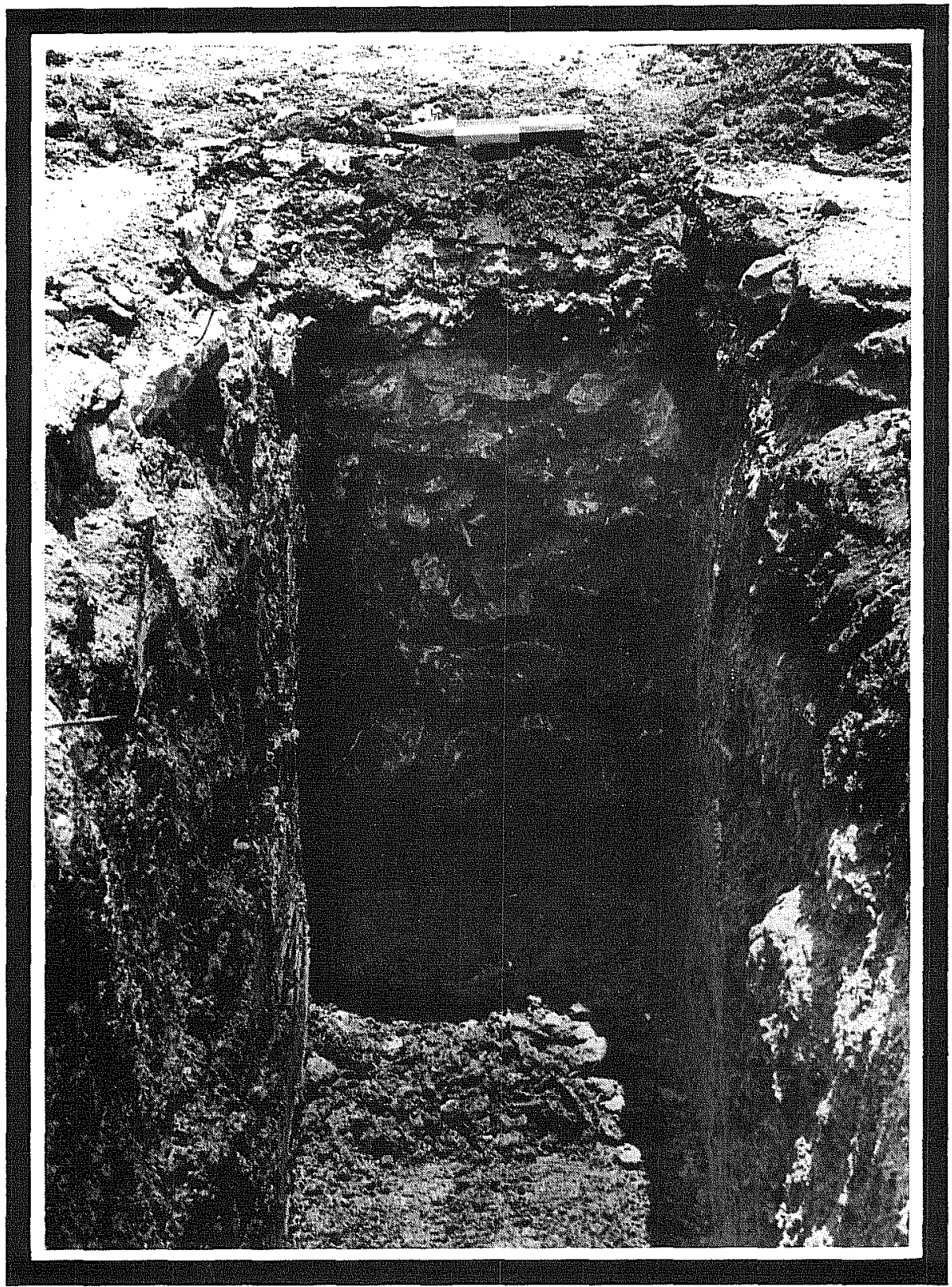

Figure 6. A Portion of the Alazan Acequia Beneath South Frio Street. 


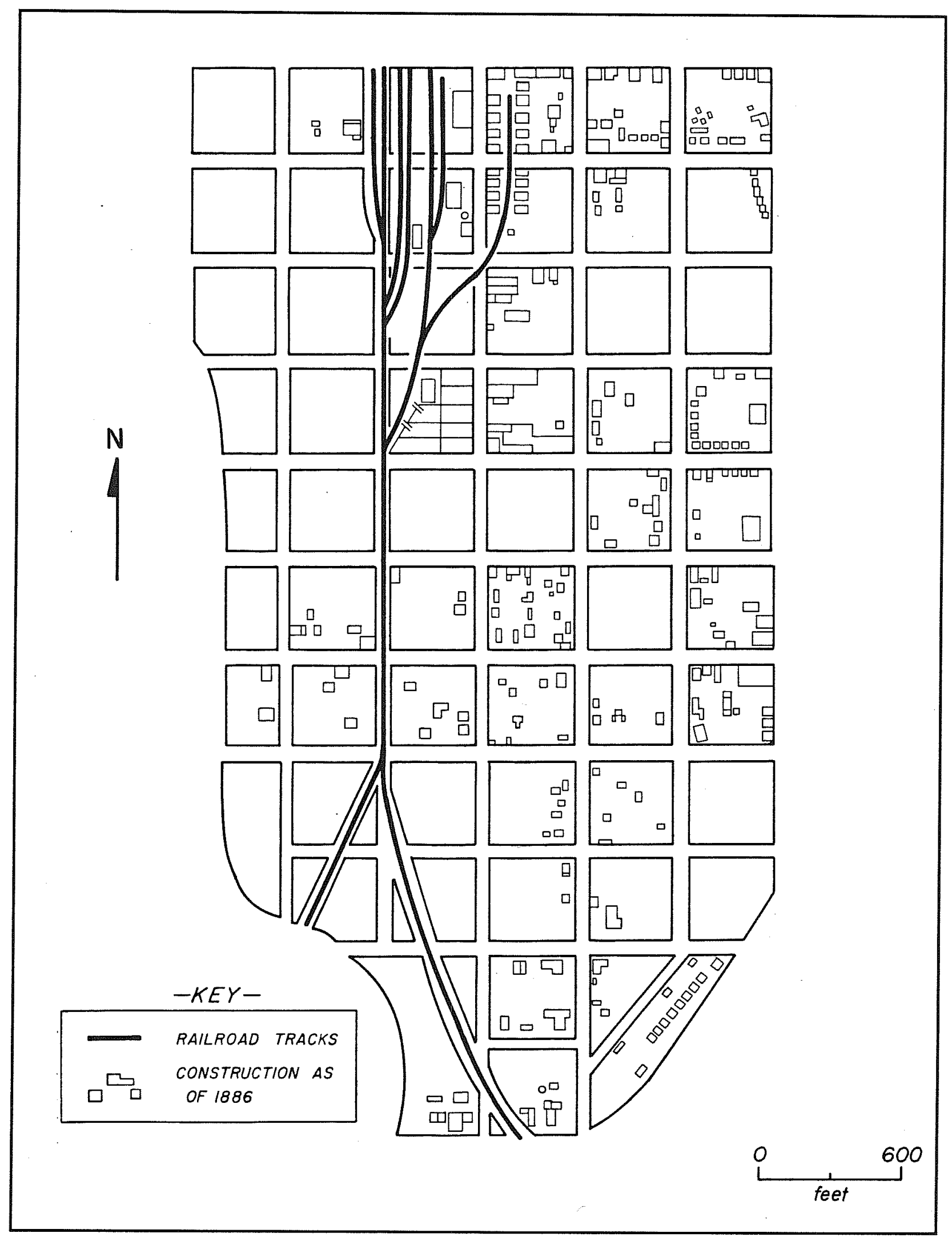

Figure 7. Commercial and Residential Structures Depicted in the 1886 Bird's Eye View Map of San Antonio. Illustration produced from Koch (1886). 
The I \& GN Railroad directly connected San Antonio to St. Louis to the north and Laredo and Mexico City to the south. Rail service provided the spark that ignited commercial and small business expansion in the area. Residential construction as well began at a pace never before witnessed, and by 1885 , schools and churches began appearing to facilitate the growth. The City of San Antonio constructed the Jose Antonio Navarro School (named after a signatory of the Texas constitution) after the acquisition of land (NCB 305). In 1886, La Trinidad United Methodist Church purchased land at the corner of South Pecos and San Fernando Streets and erected a small, single story structure. In 1891, a German Methodist Church was built at the south corner of San Marcos and Buena Vista Streets; a Missionary Baptist Church also existed near the I \& GN Railroad depot on Salado Street (see also Bobbitt 1981:13-25).

Corner grocery stores and a variety of small businesses, many family owned and operated, began operating as the project area's prosperity continued into the early 20th century. The ethnic diversity of the business owners in the area is particularly evident in some of the company names: Guenther's Grain Warehouse, Martinez Tamalina Milling Co., Ed Steves Lumberyard, and Kunz-Albaugh Lumber.

The Mexican Revolution of 1910 brought a wave of immigrants to San Antonio; many found work in the stockyards near Medina and Salado Streets. The number of vecindades (also called corrales and jacales) increased in postdepression years. Jacal-type dwellings typically have walls constructed from wooden poles and sticks which are placed in shallow, linear trenches. The spaces between the poles are filled with mud. Middle class residential construction peaked in the mid-1920s but came to an abrupt halt with the Great Depression of 1929.

The Depression forced many small businesses to close and many residences and lots to be sold. Those who could afford to move to newer neighborhoods did so. Employment in the area dropped considerably with the railroad providing the bulk of employment opportunities, most of which were unskilled labor positions. As families moved away, school enrollment declined, and church congregations dwindled as the neighborhood became increasingly ethnically homogeneous once again.

The area never fully recovered from the Great Depression. Economic prosperity and a middle class residential neighborhood were replaced by a transient population of workers who lived in existing houses and vecindades in the postdepression years of the 1930s. Some businesses reopened but most did not. The construction of I.H. 35 (completed in 1952) dealt another heavy blow to the project area, displacing still more residents and effectively cutting off the area from downtown San Antonio. The raised interstate highway cut right through what had once been a prospering neighborhood. This elevated road produced what urban sociologists term a "blighted area" as well as creating "urban alienation" among the remaining residents (Fisher 1976:214-255). This psychological impact on residents is difficult to accurately assess; small grocery stores continued closing, and school enrollment declined even more.

The final blow to the area came in 1970, when the I \& GN Railroad closed its depot and support facilities, resulting in more unemployment and causing local businesses to close. San Antonio's business district was moving north and east of the project area, and rail service was no longer profitable in the area. By 1975, student enrollment at the Jose Antonio Navarro School had dropped so low (from 2000 students in 1936 to 300 in 1975) that the San Antonio Independent School District (SAISD) Board of Education voted to close the school (SAISD 1983:2).

The decline of the Vista Verde South area was due to a combination of many factors. As with many other neighborhoods in this city and others across the nation, economic interests and a desire for progress stimulated early development. As economic trends changed with time, neighborhoods correspondingly changed in diversity and make up, followed by an eventual period of decline, culminating in a "blighted area" within a sprawling metropolitan city. The project area has witnessed and at times played an integral part in this city's social, cultural, and economic transition from a small Spanish colony to this nation's 10th largest city. The Vista Verde South project may economically revitalize this and the surrounding areas by breathing new life into a dying area of San Antonio that once typified frontier success. 


\section{SAN ANTONIO'S RED LIGHT DISTRICT}

During the late 19th and early 20th centuries, many Texas towns (Austin, Houston, and San Antonio) had a flourishing Red Light District within the city limits. San Antonio's Red Light District evolved as a distinct social and economic entity within the city limits sometime after the Civil War and by the turn of the century, San Antonio's west side district had only two peers within the continental United States: Storyville in New Orleans and the Barbary Coast in San Francisco (Davenport 1978:50).

During the 1880s, opposition to prostitution mounted in this and other cities in Texas as an evangelical wave spread across the West. In Austin, opposition was very strong, often with violent overtones (see Humphrey 1983). By 1889, San Antonio's west side Red Light District was firmly established. Organized opposition in San Antonio that year forced the City Council to pass a city-wide ordinance to "suppress and restrain bawdy houses" (CCM Vol. H:557, December 16, 1889). The resulting ordinance clearly shows the Council's ambivalence towards the issue; the document made it unlawful to:

...operate a bawdy house or house of ill-fame, or any house which persons may frequent for the purpose of prostitution or assignation unless the person or persons shall first, by written application, apply to the City Clerk of the City of San Antonio for a license to keep such a house.

The net effect of this ordinance was official sanctioning for continued operation of the west side Red Light District within certain guidelines; a clear sign that regulation rather than suppression was emerging as official city policy. Establishment licenses were fixed at $\$ 500$ annually, all "inmates" were required to undergo a physical examination (City Physician only) prior to issuance of individual licenses, and court procedures and penalties were established for noncompliance with the ordinance. Noncompliance was considered a misdemeanor charge punishable by a fine of $\$ 20-\$ 100$ and jail not to exceed 20 days; each day of violation was considered as a separate offense.

The peak of San Antonio's Red Light District may have been the years preceding World War I. By the 1910s, the City of San Antonio's brothel licensing fee for as many as 100 establishments provided upwards of $\$ 50,000$ in annual revenues alone. The Red Light District had already by this time become an institution, and had generated its own list of heroes and tales. Teddy Roosevelt's men were reputedly given the name of "Rough Riders" by the madam of one brothel after observing their style with her girls (Davenport 1978:52). Some outlaws and gunfighters called this area home. Doc Holiday and Wyatt and Morgan Earp were purported to have owned a saloon, and Jesse James and Butch Cassidy were said to have hidden in the Red Light District on several occasions (ibid.).

In 1911, the saloon keepers and brothel operators organized and published what has become known as The Blue Book (Fig. 8). This small 30-page pamphlet is very straightforward and was designed "For visitors, tourists, and those seeking a good time in San Antonio" (Anonymous 1911-1912:cover). The "Sporting District," as it was called, was said to be geographically limited: "this is the boundary which women are compelled to live by law" (ibid.:5). Others have also reported that the ladies of these establishments were forced by "City ordinance" to live inside this 10-square block brothel district (Davenport 1978:52). No evidence from City Council records has been found to support either statement; rather, it is felt that the community and neighborhood pressures were responsible for impeding expansion of the Red Light District.

Probably the most provocative feature of The Blue Book is the compilation of operating brothels and the listing of women, by name, working these establishments. Employees were listed by class (A, B, or C; the publishers do not mention how the rating was determined or exactly who provided the rating services for the publication) with addresses and telephone numbers listed as well. They charged according to their rating, $\$ 1$ for Class $A, \$ .50$ for Class B, and $\$ .25$ for Class C (ibid::51). The only discernible standard for rating Class A girls appears to be weight: as police records for the time reveal that most ' $A$ ' girls arrested weighed between 160 and 200 pounds. For $\$ 1$, a client could get an evening's worth of companionship at the gambling table, dance floor, and bar before retiring to bed (Davenport 1978:50-51).

The Vista Verde South project area includes part of this once infamous west side district (Fig. 9). Several of the "Sporting Districts" finest houses were located in the 400 and 500 blocks of Matamoras Street. No doubt, these houses were decked out with red velvet drapes, cut glass chandeliers, and brass spittoons so typical of this era. 

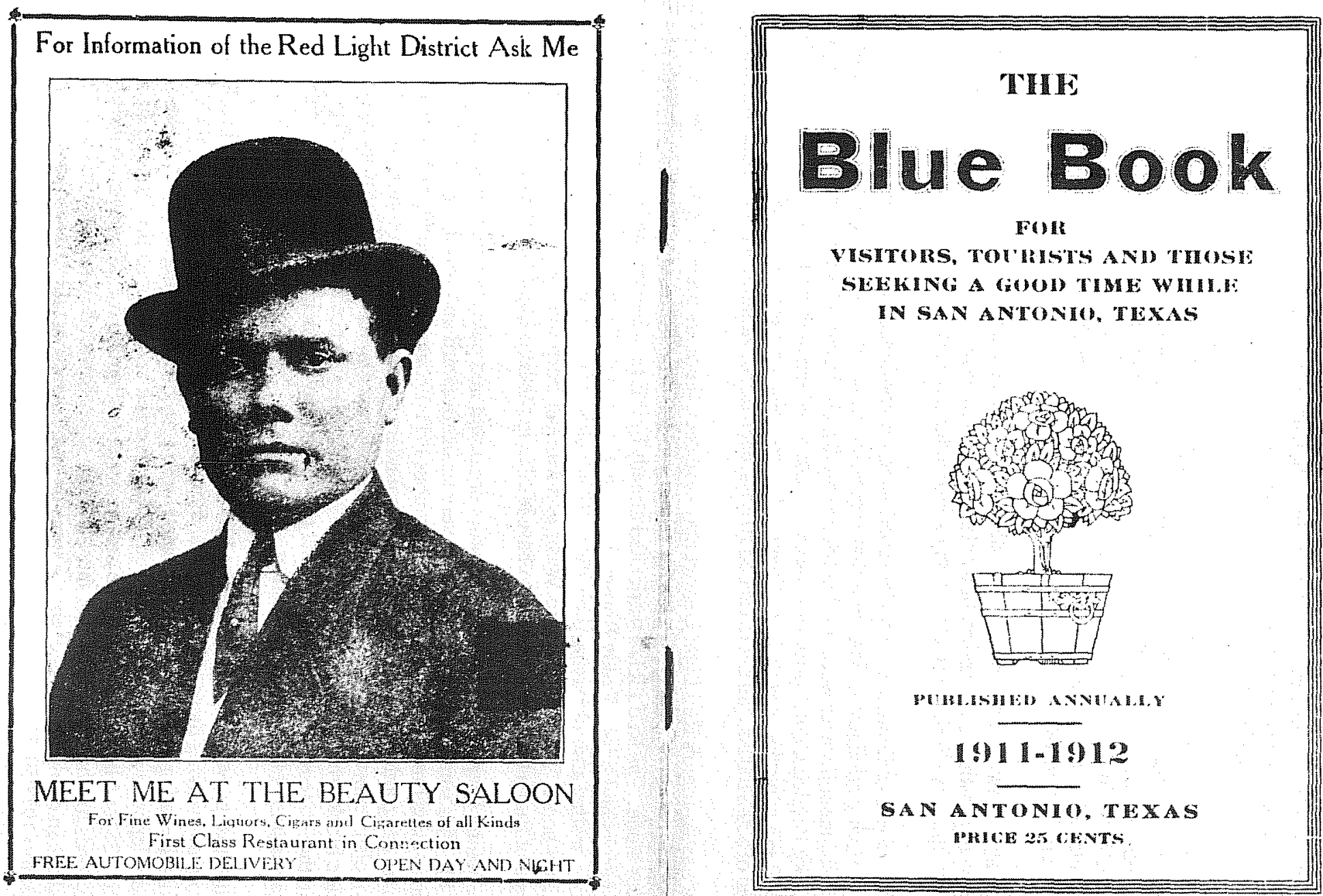

Figure 8. Front and Back Covers of The Blue Book. The Blue Book was privately published in 1911-1912. 


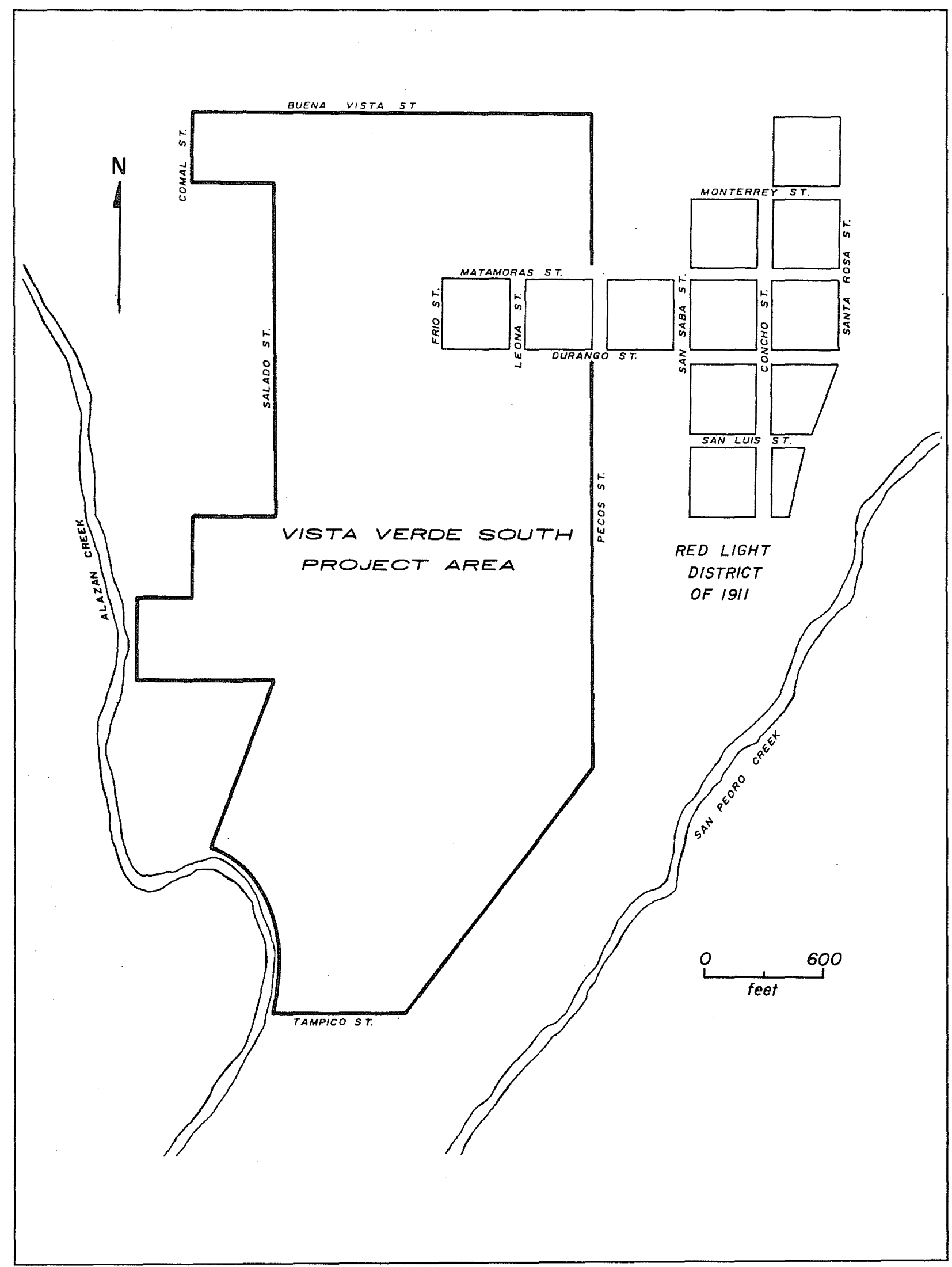

Figure 9. Location of San Antonio's Red Light District of 1911. 
Analysis of The Blue Book reveals some interesting patterns relating to the spatial distribution of the bawdy houses throughout the Red Light District. In 1911, the Red Light District was geographically segregated by the class of girls working the establishments. From the addresses listed in The Blue Book, a distinct pattern emerges (see Table 1).

\section{TABLE 1. LOCATION OF KNOWN BROTHELS ON MATAMORAS STREET IN 1911}

\begin{tabular}{lrrrr}
\hline Class of Girls & NCB & NCB & NCB & NCB \\
& 500 & 400 & 300 & 200 \\
\hline & & & & \\
Class A & 6 & 1 & 1 & - \\
Class B & 1 & 6 & 1 & 1 \\
Class C & 1 & - & - & 18 \\
\hline \hline
\end{tabular}

The Vista Verde South project areas' brothels predominantly featured Class A and Class B girls, with Class C girls restricted to an area east of the project area. It seems probable that the core of the Red Light District began on the west side of San Pedro Creek and gradually expanded to the west towards the present-day project area. The brothels in the Vista Verde South project area may have been the most opulent in the entire district; at least one house (420 Matamoras Street) was constructed specifically for use as a brothel by Dorothy McNue sometime between 1904 and 1910. (This house has been accepted for inclusion on the National Register of Historic Places.) Her neighbor, Jessie Peoples, used an existing residence for her place of business.

As noted earlier, the Great Depression severely affected many businesses in the project area. Those specializing in entertainment were particularly affected, for fewer and fewer dollars were being spent as the depression worsened. With harsher times and less money, "flim-flams" and muggings became more common in the Red Light District in an attempt to weather the postdepression years (Davenport 1978:55).

By the 1940s, the Red Light District had become a mere shadow of its former days. With the coming of World War II and the flood of soldiers to San Antonio, the area stood a chance to rebound to its former prosperity. During World War I, Fort Sam Houston's commander, "Blackjack" Pershing, thought clean prostitution was good for the troops' morale (ibid.) which no doubt furthered the establishment of the traditional town pass for troops in training. In 1941, however, Fort Sam Houston's commander, Colonel Dwight D. Eisenhower, made an about-face in policy, ordering the City of San Antonio to close down the Red Light District (Hendricks 1980). Acting on orders from Mayor Charles Quinn, Police Commissioner Preston Anderson and Sheriff Albert West proceeded to shut down the Red Light District rather than risk the loss of economic benefits brought to the city by military bases. Within a few years, the Red Light District as such no longer existed as organized; centrally located prostitution gave way to isolated, free-lance operations which spread to newer areas of the city.

Now, nearly half a century later, all that remains of the Red Light District are some old houses and fond memories among some of San Antonio's older citizens. Prostitution still makes headlines from time-to-time, and military trainees at local bases still get their traditional town pass, but the days of organized vice as an integral part of the social and economic system of San Antonio are long gone.

\section{CULTURAL RESOURCES MANAGEMENT}

Anyone who has driven through the Vista Verde South area in downtown San Antonio or read about it in the local newspapers, cannot help but be impressed by the proportions of this redevelopment plan: 31 city blocks encompassing roughly 150 acres. The project's location has focused much attention on the many old buildings and residences within the project area. The question of just what to do with these structures has been the topic of much 
debate: should they be preserved, restored, renovated, relocated, or destroyed to make room for newer buildings. Although unintentionally, the Vista Verde South project has polarized community opinions and has created the classic confrontation between the proponents for "progress" and those who desire to preserve the past for "posterity."

Only within the last few decades have we begun to realize that the historic and cultural foundations of San Antonio and our nation, for that matter, should be preserved as they provide us with a sense of orientation, direction, and identity within an ever-changing world. Whether to destroy or preserve a particular man-made element of the environment is no simple decision. More often than not, the economics of the situation and the desire for progress tend to favor destruction rather than preservation. In recent years, adaptive reuse of older buildings and neighborhoods has become quite fashionable and has meant savings in energy, time, and raw materials while maintaining the aesthetic and visual relationships that have historically defined a particular area or period. The King William and La Villita Historic Districts in San Antonio are excellent examples of the reuse of older buildings within a large metropolitan city.

This question of how to preserve the tangible links of a community's past for the future, is not a new question. A brief look at some of the major federal legislation regarding this issue demonstrates our government's concern and attempts at striking a balance between progress and preservation.

\section{FEDERAL LEGISLATION RELATING TO ARCHAEOLOGICAL/HISTORICAL PROPERTIES}

One of the earliest pieces of federal legislation addressing the issue of archaeological/historical properties was the Antiquities Act of 1906 (Public Law 59-209; 34 Stat. 225; 16 U.S.C. 431- 433). This law made federal agencies responsible and accountable for any potential impact their actions might have on archaeological, cultural, or historic resources. The Historic Sites Act of 1935 (Public Law 74-292; 49 Stat. 666; 16 U.S.C. 461-467) attempted to further define responsibilities and established a policy of preserving historic resources of national significance for public use. The Secretary of Interior was also given the authority to survey, document, and acquire historic properties. In 1960, the Reservoir Salvage Act (Public Law 86-523; 74 Stat. 220; 16 U.S.C. 469-469c) became law. Its goal was to preserve archaeological data which would have otherwise been lost due to federally sponsored dam construction programs.

The National Historic Preservation Act of 1966 (Public Law 89-665; 80 Stat. 915; 16 U.S.C. 470) has had a major impact on the preservation of archaeological and historical properties. It established the National Register of Historic Places (NRHP), making it "the official list of the Nation's cultural resources worthy of preserving" (Public Law 89-665:Preamble). This law also provided for the establishment of a State Historic Preservation Officer to administer the federal program at the state level (ibid.:Title 1, Sec. 101).

Other major pieces of federal legislation include Executive Order 11593 (May 13, 1971, 36 CFR 8921; 16 U.S.C. 470), which required the recording, preservation, and maintenance of the archaeological, historical, and cultural resources on federal lands. In 1974, the Archeological and Historic Preservation Act (Public Law 93-291; 88 Stat. 174; 16 U.S.C. 469) expanded the scope of the Reservoir Salvage Act of 1960 (Public Law 86-523) to include any federal or federally related land modification project. Most recently (1980), amendments to the 1966 National Historic Preservation Act (Public Law 89-665) became law. Other rules about the protection of historic and cultural properties are listed in the Code of Federal Regulations (36 CFR 800), Procedures for the Protection of Historic and Cultural Properties.

\section{SIGNIFICANCE OF A PROPERTY/SITE}

The term "significance" is a relative term by definition; in practice, it seems to imply different things to different people, organizations, and businesses. To the scientific and research-oriented community, the "significance" of a property (site) implies that the property contains information that may help answer important research questions. 
It follows that all research questions are not of equal importance to all. An archaeologist can develop research questions about almost any distribution of materials from prehistoric Southwest ceramics to a "typology of poptops identifying the formal characteristics of each type and brand and kind of beverage it represents" (Rathje and Schiffer 1980:207-208). By studying the behavior that produced the phenomenon, analysis of the remains, and how they were spatially distributed upon the landscape, one can always learn something. But what one can learn may not be worth learning.

The question of how many classifiable Victorian Texas Period (1874 to 1901) or Lone Star State Period (1846 to 1861) structures within the Vista Verde South project area has little scientific importance, unless it will provide a clue to answer some larger question. Anthropology frequently focuses on how cultural systems change over time. The ability to document culture change, as manifested in the temporal and spatial differences in architecture and construction materials within a defined area, may help us to understand how the environment, social, political, or economic factors inhibited or promoted culture change.

The question of what we will find in a 19th-century residential trash pit is only a matter of curiosity. But if there is something in particular about 19th-century San Antonio residents that is likely to be learned from the location, distribution, and contents, or is likely to provide information about some larger important historical event or process, then it is no longer merely a matter of curiosity.

The research design for the CAR-UTSA archaeological survey was designed to identify and test targeted sites, which might have been overlooked by the previous surveys, that could be of historical or cultural significance. Testing was directed toward determining boundaries, depths, areal extents, and general conditions; very little disturbance of the sites was necessary. Recovered artifacts from isolated trash disposal areas (NCB 276, 908 South Frio Street; NCB 280, 508-514 South Frio Street; NCB 303, 416-420 Matamoras Street) are representative for that midden area only. Generalizations or hypotheses about the larger project area are tenuous at best if based on data recovered during testing alone. Excavation of these midden areas at some future date might provide a sufficient data base to generate larger research questions relating to acculturation studies of Mexican/Anglo ideas or behaviors which would be reflected in the excavated artifacts. The point where testing ends and excavation begins is hard to define, but when sufficient information has been obtained to form a decision about the site, then excavation begins. Excavation is directed at data recovery, recovering as much of the relevant data in the site as possible, given time and other constraints.

Prehistoric archaeological sites and historical properties (sites) may be significant solely for the information they contain. Extraction of the information may not be in the public interest, which may take precedence over a site's utility for research. For example, the fact that development threatens a historic site or structure does not automatically necessitate excavation. If a site is unique or one of a kind, it should be excavated. If the site is similar to one in the vicinity that has already been thoroughly investigated, excavation may not be in the public interest. Significance alone, therefore, does not determine how a particular property should be treated. Its relationship to current and conceivable future research questions also depends on how to deal with a particular property. If it cannot be shown, after a reasonable, good faith effort to do so, that study of a given property will be useful in addressing important research questions, it should not be studied at public expense. In such cases, private investigations could be done using nonpublic funds, if a researcher felt they were warranted.

Historic properties (sites) in Texas are often classified with abbreviations developed by the Texas Historical Commission (1979). Historic buildings are classified according to their construction date (determined by archival research; see Fig. 10). Sites are further classified according to the architectural style which most closely resembles the structure's present condition (Fig. 11). A further classification is based on "theme" which identifies the property's most significant architectural and historical elements (Fig. 12).

For nonfederal projects, the State Review Board evaluates two types of nominations, individual sites and districts (a grouping of individual sites). The sites' potential for the illumination of culture-history, local sequences, inter/intra site patternings, technology or primitive industry, all affect eligibility determinations at the state level.

Classification and categorization of the historic structures within the Vista Verde South project area that have been determined eligible for nomination to the National Register of Historic Places are listed in Figure 13. 


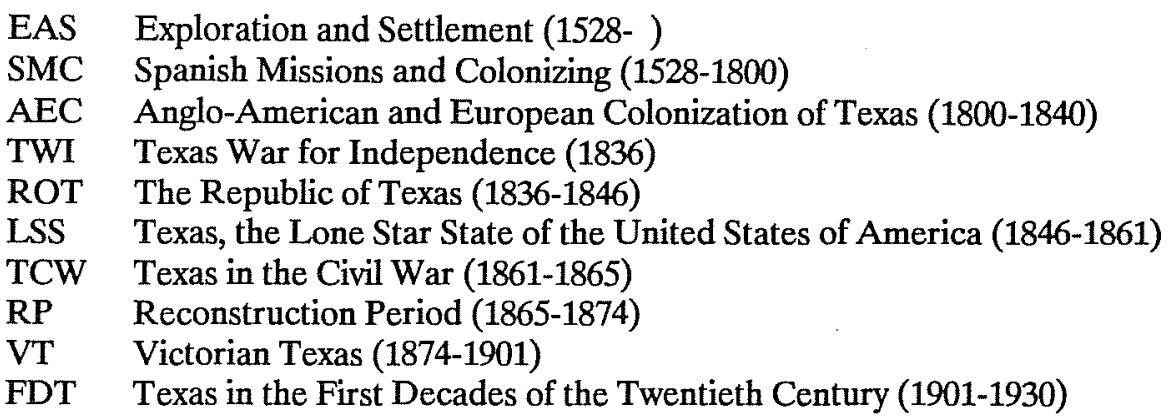

Figure 10. Period Subdivisions. Developed by the Texas Historical Commission (1979).

\section{ARCHITECTURE-18TH CENTURY}

AASC Spanish Colonial

\section{ARCHITECTURE-19TH CENTURY}

AASC Spanish Colonial

AAMC Mexican Colonial

AAGR Greek Revival

AAGO Gothic Revival

AAV Victorian

AARN Renaissance Revival

AAO Octagonal Style

AARE Romanesque Revival

AAVE Victorian-Edwardian

AAEL Eastlake

AAVI Victorian-Italianate

AAVF Victorian-Farmhouse

AAVSF Victorian-Second Empire

AAQA Queen Anne

AAVE Victorian Commercial

AASS Shingle Style

\section{ARCHITECTURE - VERNACULAR}

AAPC Pioneer Czech

AAPG Pioneer German

AAPAL Pioneer Alsacian

AAPN Pioneer Norwegian

AAPI Pioneer Irish

AAFF Pioneer French

\section{ARCHITECTURE - VERNACULAR} (continued)

$\begin{array}{ll}\text { AAPA } & \text { Pioneer Anglo } \\ \text { AAEM } & \text { Ethnic Mexican } \\ \text { AASC } & \text { Stone Vernacular } \\ \text { AAMCC } & \text { Mexican Colonial Commercial } \\ \text { AABVC } & \text { Brick Vernacular Commercial } \\ \text { AAEWC } & \text { Early West Commercial } \\ \text { AAPP } & \text { Pioneer Polish } \\ \text { AAPS } & \text { Pioneer Swedish }\end{array}$

ARCHITECTURE-20TH CENTURY

AACR Classic Revival

AAGER Georgian Revival

AAE Eclectic

AAMED Mediterranean Revival

$\mathrm{AACH}$ Chateauesque

AAJ Jacobean Revival

AAGRO Greco-Roman

AAAN Art Nouveau

AAMOR Moorish Revival

AABA Beaux Arts

AAMR Mission Revival

AAS Sulivanesque

AAPRS Prairie School Style

AAFLW Frank Lloyd Wright

AAB Bungaloid

AAM Modern

AAETC Early 20th-Century

Commercial

Figure 11. Architectural Styles. Developed by the Texas Historical Commission (1979). 


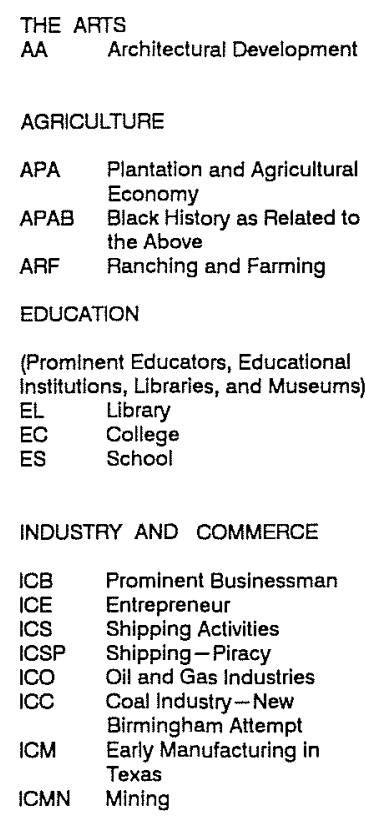

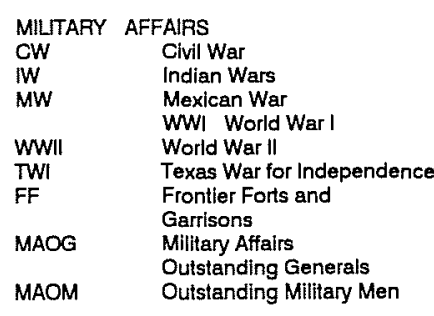

POLITICAL, AFFAIRS

PAS Statesmen

SCIENCE AND TECHNOLOGY

(Physical, Biological, Social

Sciences, and the Space Industry)

$\begin{array}{ll}\text { STA } & \text { Astronomy } \\ \text { STB } & \text { Botany } \\ \text { STM } & \text { Medicine } \\ \text { STAGR } & \text { Agriculture }\end{array}$

TRANSPORTATION AND COMMUNICATION

TCSC Old Stagecoach Lines

TCMT Mission Trails

TCCT Cattle Tralls

TCFF Frontier Forts

TCRR The Railrogd

TCRR The

$\begin{array}{ll}\text { TCEH } & \text { Early Hotels } \\ \text { TCJ } & \text { Joumalism }\end{array}$

Figure 12. Thematic Classifications. Developed by the Texas Historical Commision (1979).

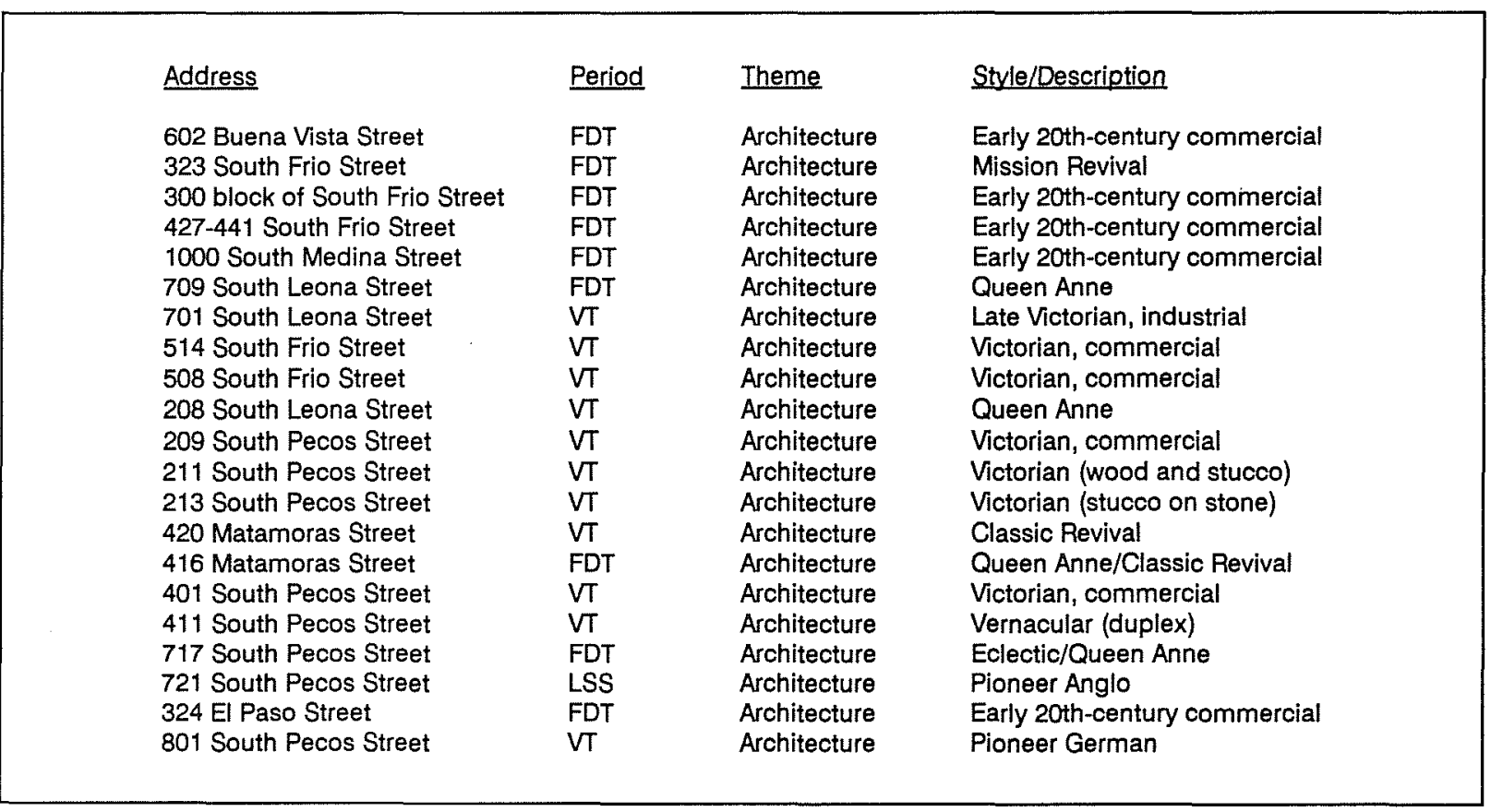

Figure 13. Period, Theme, and Architectural Style Classifications for Vista Verde South Project Properties That Have Been Determined Eligible for Nomination to the National Register of Historic Places. FDT = Texas in the First Decades of the 20th Century; LSS = Texas, the Lone Star State of the United States of America (1846-1861); VT = Victorian Texas (1874-1901). Classifications developed by the Texas Historical Commission (1979). 
The exact number of submissions for determination of eligibility to the National Register of Historic Places within the Vista Verde South project area is unclear. A review of the available correspondence relating to eligibility determinations indicates that at least 37 structures have been considered eligible by the National Park Service in Washington, D.C. (Herrington 1982). Of these 37 nominated structures, 14 were accepted, 11 returned for insufficient documentation, and 12 were rejected (ibid.). Of the 11 nominations returned, seven were eventually determined eligible after resubmission by the SHPO. The formal approval for these nominations will take several years due to the backlog at the National Park Service in Washington, D.C. For all intents and purposes, 21 structures have been determined eligible for nomination to the National Register of Historic Places as of June 1984 (Fig. 14).

Of the 21 structures determined eligible for nomination to the National Register of Historic Places (Fig. 14), over half no longer exist; two more have been damaged beyond repair by separate fires (Fig. 15). The City of San Antonio has "stockpiled" (removal of a structure from its original location to an area not immediately threatened by project development) several nominated structures, to avoid demolishing them. Several more nominated structures were still occupied as of June 13, 1984; their eventual fate still to be determined.

\section{SUMMARY}

The Vista Verde South project, which to date has consisted of nearly 15 years of planning, demolition, and construction, is still far from complete. It has been estimated that $\$ 98$ million will have been spent by the late 1980s (L. Fox 1983). As might be expected with a project of this magnitude and scale, lack of communication, miscommunication, and oversight by a myriad of administrative/logistical arms connected with the project has created a variety of problems. A case in point would be the handling of the archaeological assessment of the potentially eligible National Register properties within the project area.

The City of San Antonio in 1981, contracted for, but did not receive, an archaeological assessment for the properties in the project area; the DeLara-Almond Architects, Inc., and Bobbitt (1981) and the DeLara-Almond Architects, Inc. (1981) reports contained only a historical and architectural survey of the area. These reports did not address what might lie beneath the ground surface based on their historical and architectural research; an archaeologist was not hired as a consultant.

This archaeological survey for the project (CCM 1983) area was conducted nearly two years after the DeLaraAlmond Architects, Inc. (1981) and Breig and Associate (1981) surveys. The research design for the CAR-UTSA survey was directed at what had to be done and what could still be done. Many of the problems encountered by the CAR-UTSA survey could have been avoided by a more timely archaeological survey of the project area.

The Vista Verde South project has also demonstrated the need for the City of San Antonio to establish priorities for dealing with the city's prehistoric and historic resources within the framework of existing urban planning programs. Data from archaeological surveys, such as the CAR-UTSA survey, can be positively used to define policies and techniques that preserve irreplaceable resources which will allow for continued economic growth and physical development of San Antonio. 


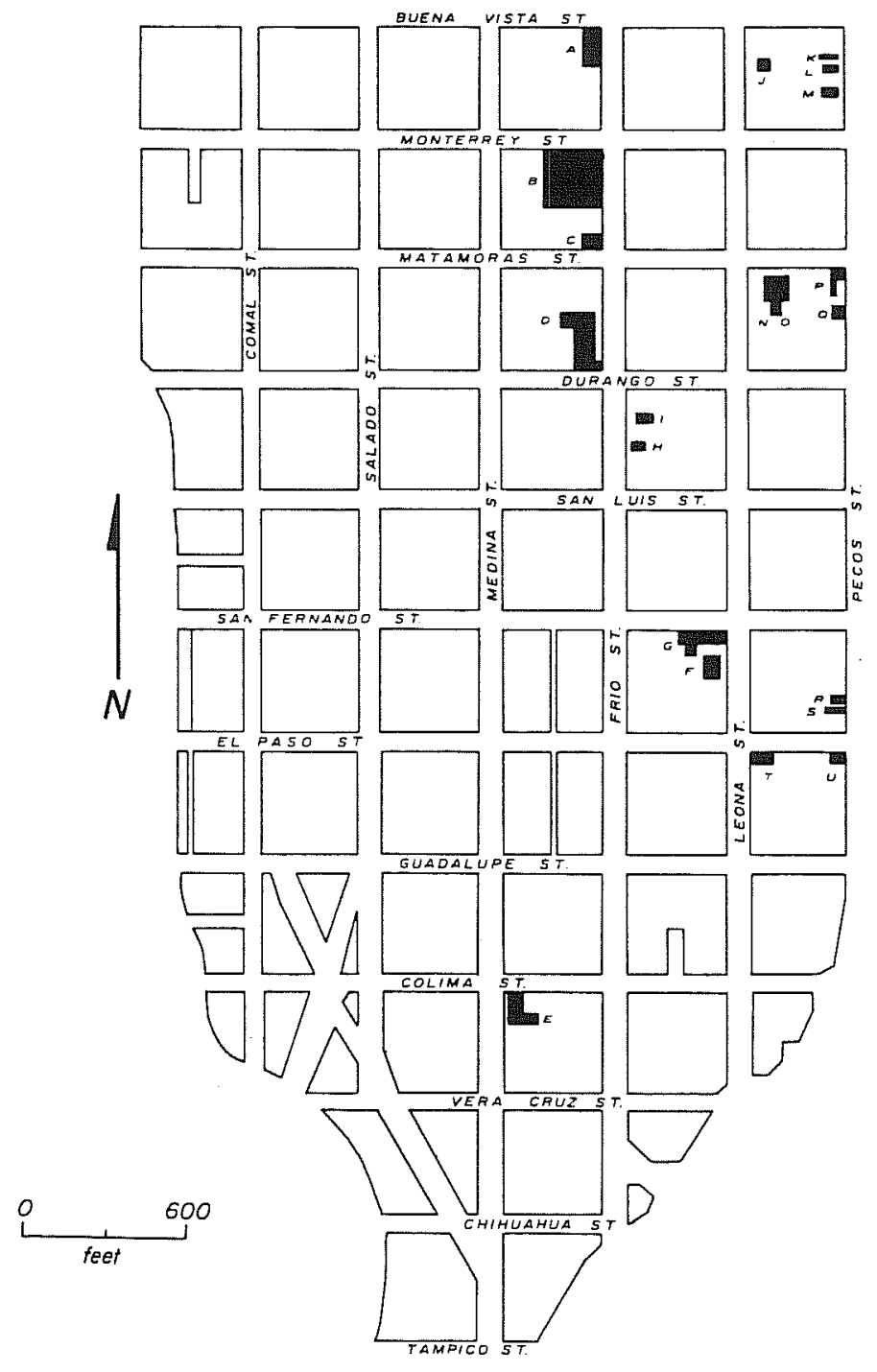

MAP.

REFERENCE

ADDRESS

602 BUENA VISTA STREET

301-315 SOUTH FRIO STREET

323 SOUTH FRIO STREET

427-441 SOUTH FRIO STREET

1000 SOUTH MEDINA STREET

709 SOUTH LEONA STREET

701 SOUTH LEONA STREET

514 SOUTH FRIO STREET

508 SOUTH FRIO STREET

208 SOUTH LEONA STREET

209 SOUTH PECOS STREET

211 SOUTH PECOS STREET

213 SOUTH PECOS STREET

420 MATAMORAS STREET

416 MATAMORAS STREET

401 SOUTH PECOS STREET

411 SOUTH PECOS STREET

717 SOUTH PECOS STREET

721 SOUTH PECOS STREET

324 SOUTH PECOS STREET

SITE

$41 \mathrm{BX} 600$

41 BX 601

41 BX 621

41 BX 602

$41 \mathrm{BX} 607$

$41 \mathrm{BX} 609$

$41 \mathrm{BX} 608$

$41 \mathrm{BX} 610$

$41 \mathrm{BX} 603$

41 BX 604

$41 \mathrm{BX} 611$

41 BX 612

41 BX 613

41 BX 614

41 BX 605

$41 \mathrm{BX} 615$

41 BX 616

$41 \mathrm{BX} 617$

$41 \mathrm{BX} 618$

41 BX 606

41 BX 619
NCB

266

267

274

278

278

280

301

301

301

391

303

$\mathbf{3 0 3}$

303

306

307

$\mathbf{3 0 7}$

Figure 14. Site Location of Historic Structures in the Vista Verde South Project Area That Have Been Determined Eligible for Nomination to the National Register of Historic Places. 


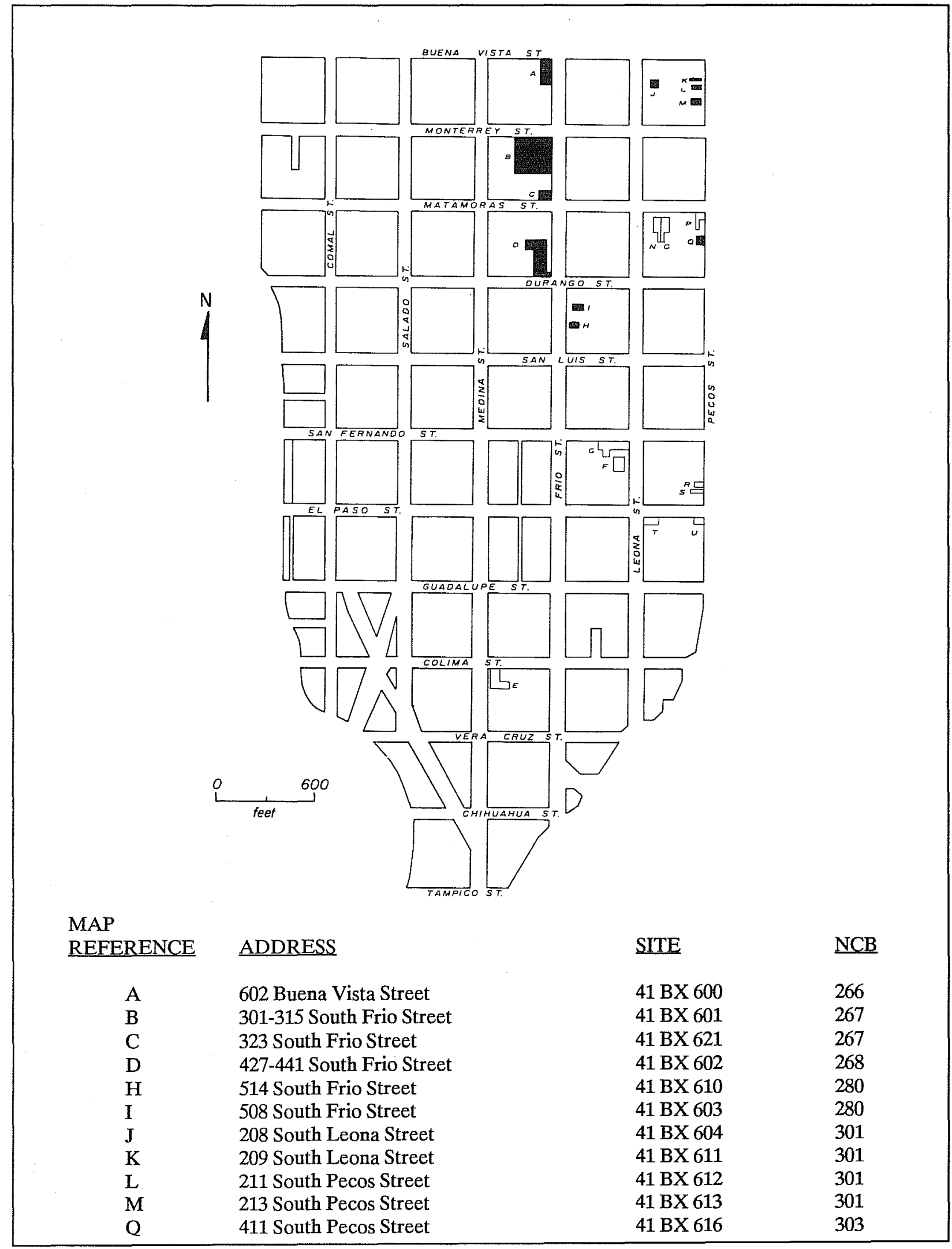

Figure 15. National Register Eligible Properties Which Have Been Destroyed by Vista Verde South Project Development. Determined as of June 1984. 


\section{ARCHAEOLOGICAL SURVEY AND TESTING}

During Phase I operations, 16 city blocks were totally surveyed by the CAR-UTSA team; during the Phase II operations the remaining 16 city blocks were surveyed (Figs. 16 and 17). The difficulties in accurate and systematic surveying encountered during Phase I were accentuated by project development which occurred in the short period between June 13 and June 27. Fill dirt, with accumulations exceeding two feet in depth in some locations, covered many areas that were otherwise clear during Phase I (NCBs 236, 237, 240,280, 281). When the survey crew returned to complete excavation of a 3- x 3-foot test pit, the entire area, including the test pit, was under several feet of recent fill dirt. Debris from demolished and bulldozed structures, as well as accumulated junk near decaying structures, further limited the areas accessible to the survey crew. The "ideal" conditions for archaeological recovery and pedestrian survey, using accepted field strategies and sampling methods, were rarely encountered in the project area.

In light of these conditions, it must be stated here that the goal of this project was not simply to excavate and recover artifacts. The main objective of the CAR-UTSA archaeological survey was to obtain information on past instances of human behavior and events (or factors that may have influenced them) which were still to be found. Analysis and interpretation of these recovered materials would then be used to assist in determinations of archaeological significance for a particular property, using criteria developed for the National Register of Historic Places.

The archaeological survey team limited its investigations to city blocks within the Vista Verde South project area that were to be acquired by the City of San Antonio. City blocks and portions of blocks within the physical limits of the project area that were not part of this acquisition were not surveyed (Fig. 17). For the city blocks that were surveyed, a block-by-block summary description is presented.

NCB 236 and NCB 237

The 1886 bird's eye view map (Koch 1886) shows both NCB 236 and NCB 237 as being vacant. The 1981 survey report (DeLara-Almond Architects, Inc. 1981) notes both blocks as without any standing structures. Survey of these blocks by the CAR-UTSA was impractical. The ground surface of both blocks was almost totally obscured by scrap metal which had accumulated over the years from use as a salvage yard operation.

\section{NCB 238}

Koch's (1886) bird's eye view map depicts several residential structures as existing on NCB 238 in 1886 . The only structure remaining when the CAR-UTSA survey team arrived was a warehouse of recent vintage. No evidences of the earlier structures were identified by this survey. Surface survey was limited (Fig. 17), due principally to the present-day ground coverage.

\section{NCB 240}

NCB 240 is bisected by railroad tracks which run north-south; otherwise, the block is entirely clear of buildings and structural debris. Most of the block was densely covered by tall sunflowers and tall grasses. The 1886 bird's eye view map (Koch 1886) depicts this block as being vacant. The lot was vacant in 1981 (DeLara-Almond Architects, Inc. 1981).

A chert flake was found on the surface near the railroad tracks; technological analysis indicated that it was most probably the product of an accidental fracture and was not produced by deliberate manufacture. No other potential indications of prehistoric artifacts were noted. Shovel testing failed to locate any indications of significant deposits or features of archaeological interest. 


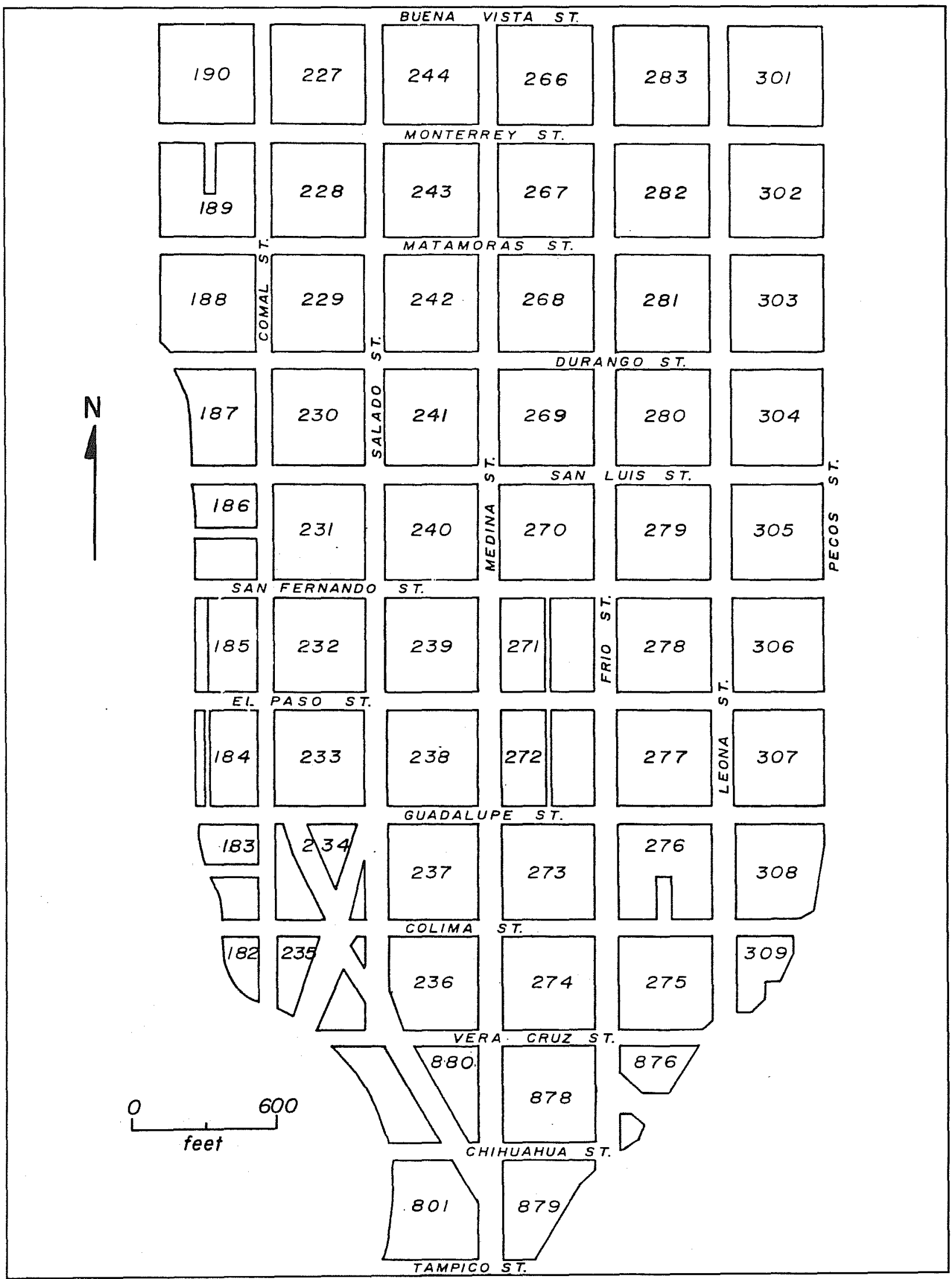

Figure 16. NCB Designations Within the Vista Verde South Project. 


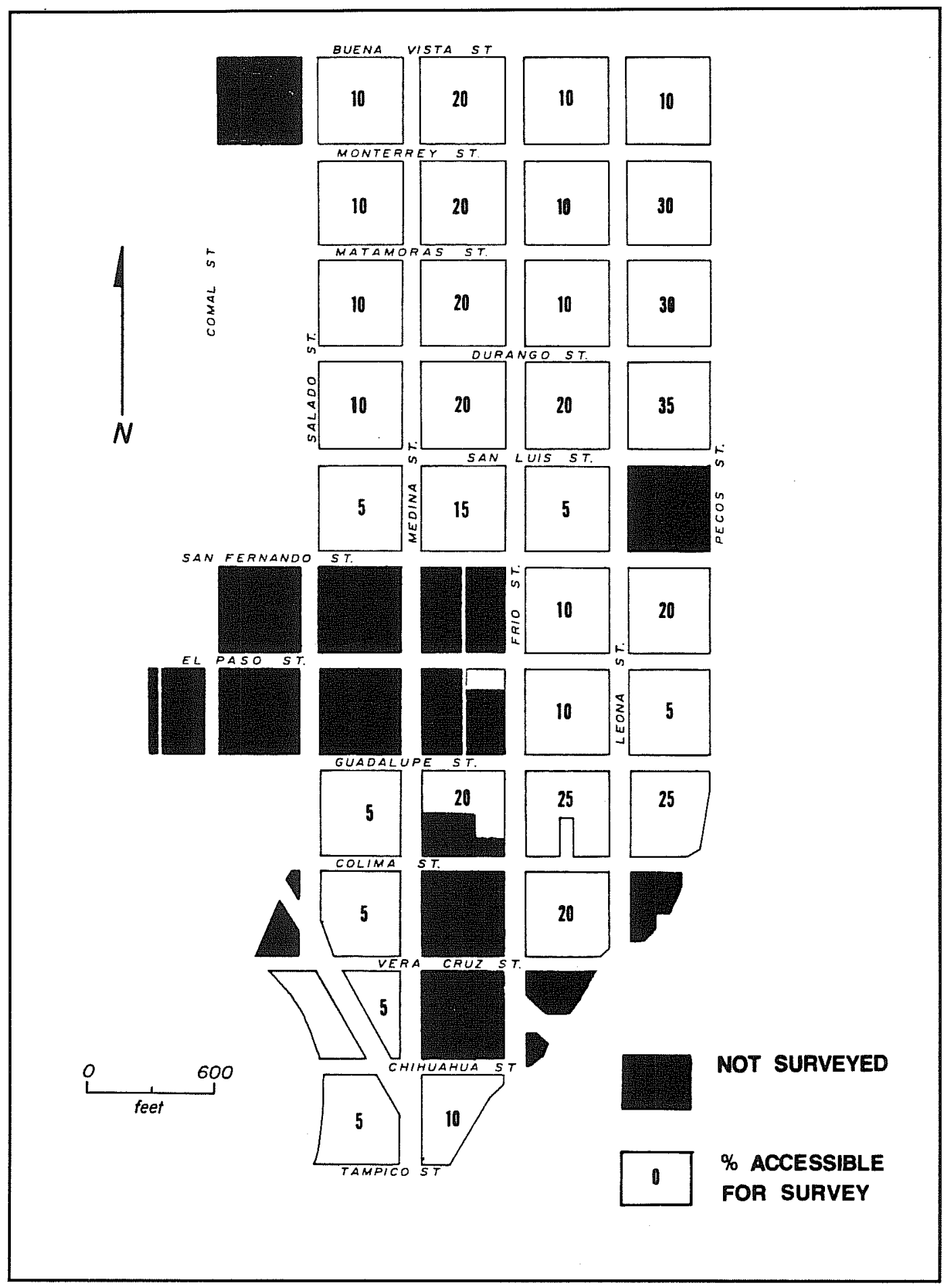

Figure 17. Location of City Blocks Surveyed and the Percentage of Each Block Accessible to Survey. 
NCB 241 is bisected by the same set of railroad tracks noted for NCB 240 . The 1886 bird's eye view map of San Antonio (Koch 1886) depicts several structures in the immediate vicinity of the railroad tracks; no evidence for these structures was located by this survey. The block had been cleared of all structures but still contained a parking lot associated with one of the former structures. Several depressions from bulldozing activity were noted as well as piles of recent earthen fill.

Two shovel test (ST) probes were made in an area which appeared to be relatively undisturbed; they revealed two different soil profiles. ST-1 (8 inches in diameter $\mathbf{x} 8$ inches in depth) exposed three distinctive strata: (1) loose, light brown sandy soil; (2) brown sandy soil with a reddish tint that included a relatively high proportion of well rounded and sorted gravel; and (3) compact gravel with a low proportion of sand and dirt. ST-2 (8 inches in diameter $x 16$ inches in depth) exhibited a different sequence of soil profiles: (1) identical to stratum 3 in ST-1; (2) loose, dark brown to black soil with gravels limited to the interface between strata 1 and 2; and (3) loose, very dark soil which contained fragments of coal, mussel shell, and bits of glass. The shell and glass fragments were the only artifactual materials recovered from either shovel test probe and are not considered to be of archaeological significance. The difference in soil profiles is related to the differential machine blading and leveling in the vicinity of the shovel tests. The area of ST-2 has had the upper 8-10 inches of soil removed whereas the area of ST-1 has not been disturbed at all.

This block has undergone differential machine leveling operations and earthen fill dumping with no evidence of previous structures remaining. Intensive surface survey failed to locate any significant archaeological deposits or features on NCB 241.

\section{NCB 242}

The 1886 map (Koch 1886) depicts NCB 242 as being vacant. No structures existed, except for the concrete railroad platform, in 1981 (DeLara-Almond Architects, Inc. 1981). When the CAR survey crew arrived, the only remaining structure was an old concrete railroad cargo platform adjacent to a set of railroad tracks which bisect the block running north-south. The remainder of the block was almost entirely covered with recent earthen fill. Many of the piles of fill contained glass, metal, and structural debris; no such materials were found in undisturbed areas. The CAR survey did not locate any significant archaeological deposits.

\section{NCB 243}

The CAR survey crew recorded only one intact building, owned by the Wright Oil Company in NCB 243. This brick masonry warehouse was constructed sometime between 1883 and 1886, and was leased by the Waters-Pierce Oil Company (Bobbitt 1981:38). This structure appears on the 1886 bird's eye view map (Koch 1886) of San Antonio.

Those areas not covered by the Wright Oil Company building (approximately $30 \%$ of the block) were covered with recent fill dirt with depths exceeding two feet in some areas. Subsurface testing was not practical as no original ground surfaces were readily accessible. No important archaeological remains were found by the survey team.

\section{NCB 244}

NCB 244 is bisected by railroad tracks and contains only one intact building owned by Swift and Company which uses the structure for meat packaging operations. This two-story structure was built between 1900 and 1904 (DéLara-Almond Architects, Inc. 1981). NCB 244 represents only a portion of the original city Lot 87 (Fig. 4) which was purchased by Oscar B. Brackett before 1849. Bobbitt (1981:40) reported that this block was purchased by Emily W. Brackett in 1851. By 1873, H. B. Adams and E. D. L. Wickes had acquired this block (BCDR Vol. 
11:289) as well as NCBs 242 and 243. This three-block section was sold to the I \& GN Railroad in 1880 (BCDR Vol. 12:20); rail service began on February 16, 1881 (Corner 1890:4). The 1886 bird's eye view map (Koch 1886) of San Antonio shows a concentration of buildings (depot and warehouses) on this three-block corridor (Fig. 7), but none of these structures (or remaining foundations) appear to be those depicted in the 1886 map, except for the structure noted on NCB 243 (Waters-Pierce Oil Company).

Those areas not covered by the Swift and Company building or adjacent concrete slabs were covered by four- to five-foot deep piles of recent fill. The area west of the railroad tracks is somewhat lower than the rest of the block and represents the least disturbed portion of the block. Intensive surface survey failed to locate any deposits or features of archaeological significance.

What appears to be an old, handwritten ledger book was found on the Swift and Company loading dock. The book contains detailed listings of railroad car numbers, destinations, and company names to whom merchandise (not specified) was being shipped for the years of 1923-1924. This ledger may be from the Steves Lumber Company, but as yet, has not been positively identified.

\section{NCB 266}

NCB 266 (and NCB 267) was originally owned by Oscar B. Brackett in 1849 (Giraud 1849). The property was sold to Ed Steves by H. B. Adams and E. D. L. Wickes in 1881 (BCDR Vol. 19:114).

The bird's eye view map (Koch 1886) depicts at least 16 individual structures as existing in 1886; the block contained two intact structures when visited by the CAR survey team: a one-story stucco and frame commercial/ industrial building (post-World War I) and a two-story brick commercial building built in 1919 by the Wright \& Saunders Company (DeLara-Almond Architects, Inc. 1981). Most of this block was inaccessible for survey due to the buildings, ground coverage, and adjacent concrete/asphalt paving.

In 1919, Ed Steves and Sons Lumber Company had the two-story brick building constructed as part of their lumberyard operations which also covered NCB 267 (see Bobbitt 1981:42-46 for the history of the company). By 1935, this warehouse was leased to the Finck Cigar Company (established in 1893 at a different location). Both former occupants of this building are still operating in San Antonio but at new locations, and both are considered to be among San Antonio's early industrial companies. The warehouse, located at 602 Buena Vista Street, is considered eligible for nomination to the National Register of Historic Places and was previously surveyed by the Texas Historical Commission and the City of San Antonio in 1977. This structure is shown in the appendix (Fig. 31,a).

Backhoe trenching at the southern edge of NCB 266 located the west wall of the Alazan Acequia constructed in 1875-1876 (Fig. 6). The east wall of the acequia lies beneath South Frio Street, and a modern utility line runs down the approximate center of the acequia. This utility line was observed in a Southwestern Bell Company trench being dug at the same time as this survey just north of NCB 266 (Anne A. Fox, personal communication). No other significant archaeological features or deposits were found.

\section{NCB 267}

NCB 267 is predominantly (80\%) commercial in nature, with recent fill covering the remainder of the block. Among the intact structures, two are of historical significance ( 321 and 323 South Frio Street). One structure was designed and constructed by Leo M. J. Dielman for the Steves Sash and Door Company in 1907 (DeLara-Almond Architects, Inc. 1981). The structure is one story and is constructed of brick/stone. This building was still in excellent condition when the CAR team arrived on site, although unoccupied.

The second structure ( 323 South Frio Street) is a two-story brick masonry fire station constructed in 1924 and is still in active service. It is rectangular in plan, with two drive-through bays flanking a central entrance. Curvilinear parapets extend above a gabled roof and are trimmed in cast stone copines. All doors and windows are surrounded by cast stone. The central entrance is surrounded by ornate stone, with an entablature which forms a balcony for 
French doors above (DeLara-Almond Architects, Inc. 1981). This structure is shown in the appendix (Fig. 32,a). Both of the buildings on NCB 267 had been previously surveyed by the Texas Historical Commission and the City of San Antonio in 1977.

Those areas not covered by buildings were mostly littered with chunks and large pieces of asphalt; a thin veneer of gravel covered the surface below. Lumber, metal barrels, and a variety of structural debris were intermingled with the asphalt pieces. No significant archaeological features or deposits were identified.

\section{NCB 268}

The 1886 bird's eye view map (Koch 1886) depicts a number of commercial structures as existing on NCB 268 . When surveyed by the CAR team, this block was almost entirely covered by intact commercial structures; the only portion of the block accessible for survey was a narrow gravel driveway which ran between several of the buildings. No significant archaeological features or deposits were identified.

The only structure of architectural or historical significance on this block is located at 427-441 South Frio Street; it was originally constructed for the Merchants Ice Company in 1913-1918 (DeLara-Almond Architects, Inc. 1981). This company was one of the city's earliest ice manufacturers. The structure has been determined eligible for nomination to the National Register of Historic Places, and was also included in the San Antonio Historic Survey, 1972 (O'Neill et al. 1972). The structure is shown in the appendix (Fig. 32,b).

\section{NCB 269}

NCB 269 is predominantly commercial in nature with most structures still intact. Several buildings have been demolished; red and yellow bricks, glass, and structural debris litter much of the area not covered by standing structures. Recently deposited gravel was stockpiled in several areas. The 1886 Koch map depicts several commercial structures as existing on this block; no evidences for them were identified by the CAR survey team. Intensive survey between gravel piles and structural debris failed to locate any features or deposits of archaeological significance.

\section{$\underline{\mathrm{NCB}} 270$}

The 1886 bird's eye view map (Koch 1886) depicts NCB 270 as vacant. The block had been completely cleared of all structures and debris by the time the CAR survey team arrived on site. The 1981 survey report (DeLara-Almond Architects, Inc. 1981) notes five structures, all of which were of modern construction. There was a general rise in elevation from the center to the western portion of the lot produced by recent fill dirt leveling. Heavy fill cover was evident over $50 \%$ of the block. Relatively clear surface areas were surveyed; bits of glass, ceramic pipe, asphalt chunks, pieces of plaster, and other urban debris of "modern" vintage were noted but not collected.

The Alazan Acequia runs beneath South Frio Street, parallel to the eastern portion of NCB 270 (Fig. 5). No archaeological features or deposits of significance were identified in NCB 270.

\section{NCB 272}

A small portion of the northeast corner (lot 1) was the only area of survey for NCB 272. The 1886 bird's eye view map (Koch 1886) depicts a structure existing at this location (Fig. 7). By the time the CAR team arrived on site, the entire area had been cleared of all structural remains. A somewhat raised, linear earthen feature denoted a previous structural foundation, but it does not appear to be the one illustrated in the 1886 map. Earthen fill containing bits of glass, wood, plaster, and tile covered much of the surface; no significant archaeological features or deposits were identified during shovel testing. 
The survey of NCB 273 was limited to lots (1-6) which front on Guadalupe and South Frio Streets. Several residential structures were depicted in the 1886 bird's eye view map (Koch 1886; Fig. 7); no evidence for their presence was identified during this survey. Approximately $50 \%$ of the present ground surface was covered with earthen fill which contained a relatively high percentage of urban debris. Intensive survey failed to isolate any features or deposits of archaeological significance.

\section{$\underline{\mathrm{NCB} 274}$}

NCB 274 was not surveyed as this block was not to be acquired for the Vista Verde South project. A building, located at 1000 South Medina Street, is worthy of note as it retains a portion of an original structure built in 1912 by Leo M. J. Dielman (DeLara-Almond Architects, Inc. 1981) for the Tamalina Milling Company of San Antonio. Tamalina was the name and process patented by Bartolo Martinez (owner of the milling company) for dehydrated masa (cornmeal base for making tortillas; Bobbitt 1981:56). This structure was determined eligible for nomination to the National Register of Historic Places.

\section{NCB 275}

NCB 275 presented the survey crew with a somewhat different situation than previously encountered, but typical of historical archaeological surveys in urban areas throughout the United States. Some structures had already been demolished and removed (south side), other buildings were being demolished (south and west sides), a few dwellings were still occupied (east side), and on the northern portion of the block, new homes were under construction. In 1981, twelve structures existed on the lot (DeLara-Almond Architects, Inc. 1981); all were 20th-century constructions.

Access to the remaining $30-35 \%$ of the block was limited, primarily due to the activities already noted. Intensive surface survey failed to identify any features or deposits of archaeological significance.

\section{NCB 276}

NCB 276 had once contained small houses and neighborhood stores of late 19th-century and early 20th-century vintage; most had been removed by the time the CAR survey team arrived on site. The 1981 survey report (DeLaraAlmond Architects, Inc. 1981) notes 32 residential structures for this block. Using the period subdivisions developed by the Texas Historical Commission (1979) for classification of buildings (Fig. 10), six of the 32 structures were identified as belonging to the Victorian Texas (VT) Period (1874-1901), and 23 were thought to have construction dates during the period identified as Texas in the First Decades of the Twentieth Century, 1901-1930 (FDT).

Some of these structures had been or were being demolished while the survey team was on site. Open areas around structures and vacant lots were closely examined; some contained fill dirt in depths exceeding two feet. An area behind a vacant structure (908 South Frio Street) was selected for a linear series of five shovel test probes. These shovel test probes were placed along the lot property line (Fig. 18) in an attempt to locate privies/trash pits. It was a common practice during the late 19th and early 20th centuries to locate such household disposal areas along fence lines and property boundaries (Anne A. Fox, personal communication). Backfill dirt and soil profiles of a Southwestern Bell Telephone Company pipe trench, parallel to and east of South Frio Street, yielded no evidence of subsurface deposits.

The ground surface in the general area of the five shovel test probes behind 908 South Frio Street was littered with urban debris, presumably brought with the earthen fill which covered the surface in depths from six to eight inches. The surface was also somewhat uneven due to differential machine scraping and grading. 


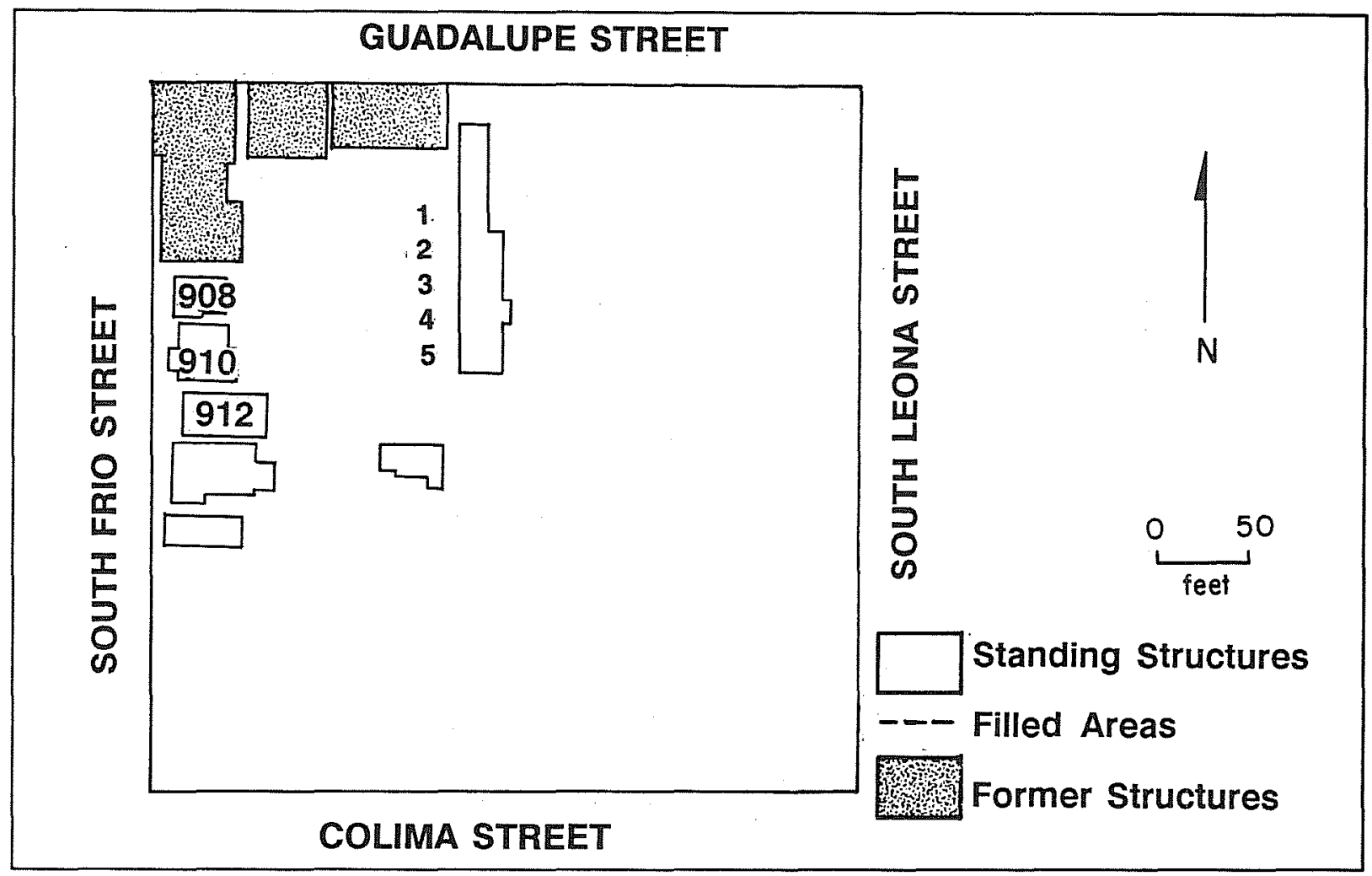

Figure 18. Location of Shovel Tests Behind 908 South Frio Street, NCB 276.

ST-1 (12 inches in diameter $x 17$ inches in depth) revealed that the upper six inches was composed of recent fill containing bits of glass, ceramic pipe, and metal fragments. From seven to ten inches below the surface (soil Zone 2), the soil was a grayish black loam with a high proportion of caliche pebbles towards the bottom of the zone. Glass fragments (green, clear, window), ceramics (lead glazed, ironstone, modern porcelain), plastic, and brick fragments were encountered at this level. In Zone 3 (10-17 inches), artifactual materials were absent. The soil became increasingly more compact and contained increasingly higher proportions of clay and may represent the original ground surface during the late 19 th century.

ST-2 (12 inches in diameter $\mathrm{x} 20$ inches in depth) produced a similar soil profile and similar artifactual materials as ST-1. Zone 1 (fill dirt) extended to a depth of seven inches. Zone 2 (7-16 inches) contained much higher frequencies of glass and ceramic items (beverage bottles, whiteware, lead-glazed and hand-painted ceramic sherds) than ST-1. Zone 3 (sterile) was encountered at a depth of 16 inches and extended to the bottom of the shovel test (20 inches).

ST-3 (12 inches in diameter $\mathrm{x} 12$ inches in depth) contained eight inches of recent fill dirt (Zone 1), then a thin deposit of artifactual materials (Zone 2, 8-10 inches), and sterile soil at 10 inches below the present-day surface. Recovered materials were limited to glass and ceramic sherds; several pieces of plastic (post-1950) were found near the interface of Zones 1 and 2.

ST-4 (12 inches in diameter $\mathrm{x} 15$ inches in depth) was placed in an area that appeared to be the least disturbed. Caliche pebbles were found immediately below the surface in Zone 1 (recent fill); in ST-1, ST-2, and ST-3, caliche pebbles were limited to Zone 3. In Zone 2 (4-9 inches), one glass beverage bottle fragment and one ceramic bottle fragment were found. In Zone 3 (sterile), the soil became increasingly darker and more compact. At the bottom of ST-4, the soil was homogeneous, black, and very friable in consistency.

ST-5 (12 inches in diameter $\mathrm{x} 15$ inches in depth) provided a soil profile consistent with previous shovel tests. Recent surface disturbance was evident (fill dirt and urban debris), extending to a depth of eight inches (Zone 1). 
Soil Zone 2 consisted of sandy clay loam approximately three inches in thickness. The only artifacts recovered from the zone consisted of a two-inch square of white bathroom-type ceramic tile and an undatable piece of glass. Zone 3 extended from 11 inches to the bottom of the hole.

When the data from each of these five shovel test probes are viewed collectively, several patternings are discernible (Fig. 19). Artifactual materials were sandwiched between zones of recent fill and sterile soils. The density of artifactual materials decreases in this linear series of shovel tests as you move south. Except for ST-4, recent fill dirt accumulation is consistent, varying from six to eight inches in depth. ST-4 had no fill dirt on the surface, which was also slightly lower than the surface for adjacent shovel tests. All artifacts recovered are presumed to be post19 th century with no diagnostic materials attributable to the late 19th century. The frequency, intensity, and proximity of these artifacts would seem to denote a trash disposal area. This is the first evidence found for the existence of trash disposal along the back fence/property lines of late 19th-century houses in the area.

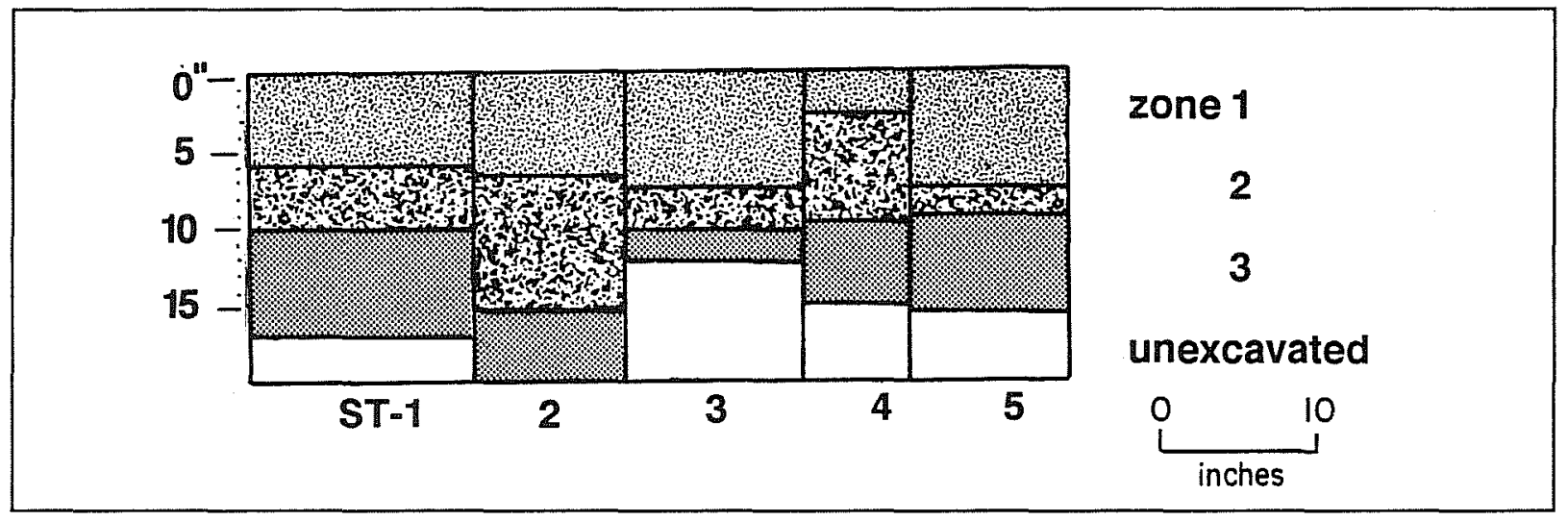

Figure 19. Composite Soil Profile for Shovel Tests 1-5, NCB 276.

\section{NCB 277}

NCB 277 contained intact residential/commercial structures which covered approximately $60 \%$ of the block; another $15-20 \%$ was covered by recent earthen fill that contained a high percentage of urban debris (glass, wood, metal). The 1886 bird's eye view map (Koch 1886) depicts several structures on this block (Fig. 7); no evidences for them were identified during this survey. Of the 19 structures identified in 1981 (DeLara-Almond Architects, Inc. 1981), only a few remain. Intensive surface and subsurface testing failed to locate any deposits or features of archaeological significance.

\section{NCB 278}

NCB 278 contained several of the Tamalina Milling Company buildings (see survey results for NCB 274 also) on lots 9 and 10. Lot 9 contained a brick residential dwelling which was constructed in 1903 by Ricardo Ortiz (DeLara-Almond Architects, Inc. 1981). The structure at 709 South Leona Street served as the residence for Bartolo Martinez and his family from 1903 to 1921 (Bobbitt 1981:56). (The structure is shown in the appendix as Figure 40,b.) This pattern, commercial operation with residence next door, was common for small businesses in the Vista Verde South project area during the late 19th century through the early years of the Great Depression in the 1930s. Most of the remaining, intact structures on this block are unoccupied residential structures which are post-1930 in construction date; the block was vacant in 1886 (Koch 1886; Fig. 7).

The northwest portion of this block had been recently cleared of all structures. Bathroom tile, plaster, and lumber littered much of the surface area; all modern in date. In the northeast corner, a large area behind the Tamalina Milling Company and brick residential structure was clear and accessible for survey. The southeast and southwest portions of this block were inaccessible for survey due to lumber storage, paved parking areas, and commercial 
building coverage. These accessible areas (approximately $10 \%$ of the block) were intensively surveyed but failed to produce any deposits or features of archaeological significance.

\section{NCB 279}

Approximately $50 \%$ of NCB 279 was covered by intact structures ( $70 \%$ residential, $30 \%$ commercial). Most of the surface not covered by buildings was covered by one foot of recent fill; less than $5 \%$ of the total ground surface for this block was accessible for survey. No deposits or features of archaeological significance were found.

The 1981 architectural survey report (DeLara-Almond Architects, Inc.) of this block notes 16 structures standing, with construction dates evenly split between the FDT Period (Texas in the First Decades of the Twentieth Century, 1901-1930) and the VT Period (Victorian Texas, 1874-1901). Several houses are worthy of note: a one-story stucco wood frame house, ca. 1886-1882 (604 South Frio Street) and a one-story wood frame house, ca. 1892-1907 (610 South Frio Street). The 1886 bird's eye view map (Koch 1886) depicts several structures on NCB 279 (Figs 7); no evidence of these structures was found by the CAR survey team.

\section{$\mathrm{NCB} 280$}

In 1886, NCB 280 contained at least six structures (Koch 1886; Fig. 7); no evidence for these structures was identified by the CAR survey. In 1981, this block contained 26 structures (DeLara-Almond Architects, Inc. 1981) of which $25 \%$ were classified as belonging to the VT Period (Victorian Texas, 1874-1901). When surveyed by the CAR team, only three structures remained; two (508 and 514 South Frio Street) have been determined eligible for consideration by the National Register of Historic Places. (These two structures are shown in the appendix as Figures $33, b ; 34, a$.$) Fill dirt covered the areas of former structures with about 20 \%$ of the total ground area accessible for survey.

Surface survey was concentrated behind the structures at 508 and 514 South Frio Street. Surface collection and subsurface shovel test probes revealed considerable disturbance in the area. Shovel tests behind 508 South Frio Street during the Phase I survey revealed artifactual deposits beneath the surface at a depth of six to eight inches. A three-foot-square test pit was laid out to further investigate the deposit, but could not be completed within the arbitrary time limit for the Phase I survey. When the crew returned to this test pit during Phase II, it was found that several feet of fill dirt had been dumped over the area of the unit which was only relocated by measurement from a previously established datum point. The pit was not reopened during Phase II.

Survey of this block included intensive subsurface testing in an effort to isolate trash disposal areas which might be adjacent to the property/lot boundaries behind 508 South Frio Street (Fig. 20). The results from a linear series of three shovel test probes indicated that rich deposits, all dating from ca. 1880-1930s, lay buried below the presentday surface. Sterile soil (Zone 3) was encountered at approximately 12 inches for all three shovel tests (Fig. 21). Artifacts recovered include cut and wire nails, stoneware, whiteware, lead-glazed ceramics, and a variety of other glass and ceramic fragments. The diversity of these recovered materials seems indicative of a residential disposal area. The fourth shovel test (Figs: 20 and 21) was excavated to see if the frequency of artifacts diminished or increased south of the original linear series of shovel tests. This shovel test indicated that the intensity of artifactual materials increased substantially and warranted further investigations. A 3- x 3-foot-square test pit was used to open a larger area to provide more detailed information on the stratigraphy, horizontal distributions, and artifact associations. The test pit was excavated to a depth of 16 inches. There were no discernible soil changes from the top to the bottom of the unit; contemporary bottle glass was present from top to bottom intermixed with diagnostic artifacts dating from the 1880 s to the 1930s. This was important, as it suggested that the recovered materials were not in a primary context and that recent bulldozing and ground leveling operations had altered the natural stratigraphy. Horizontal distributions and artifact associations could not, therefore, be confidently made; also associations between the test pit and the four shovel tests were not possible, although artifacts recovered from these test probes appeared to be in primary context. Although recovered from a secondary context, analysis of the materials provided basic information on the nature and character of residential disposal activities during the late 19 th and early 20 th centuries for the project area. 


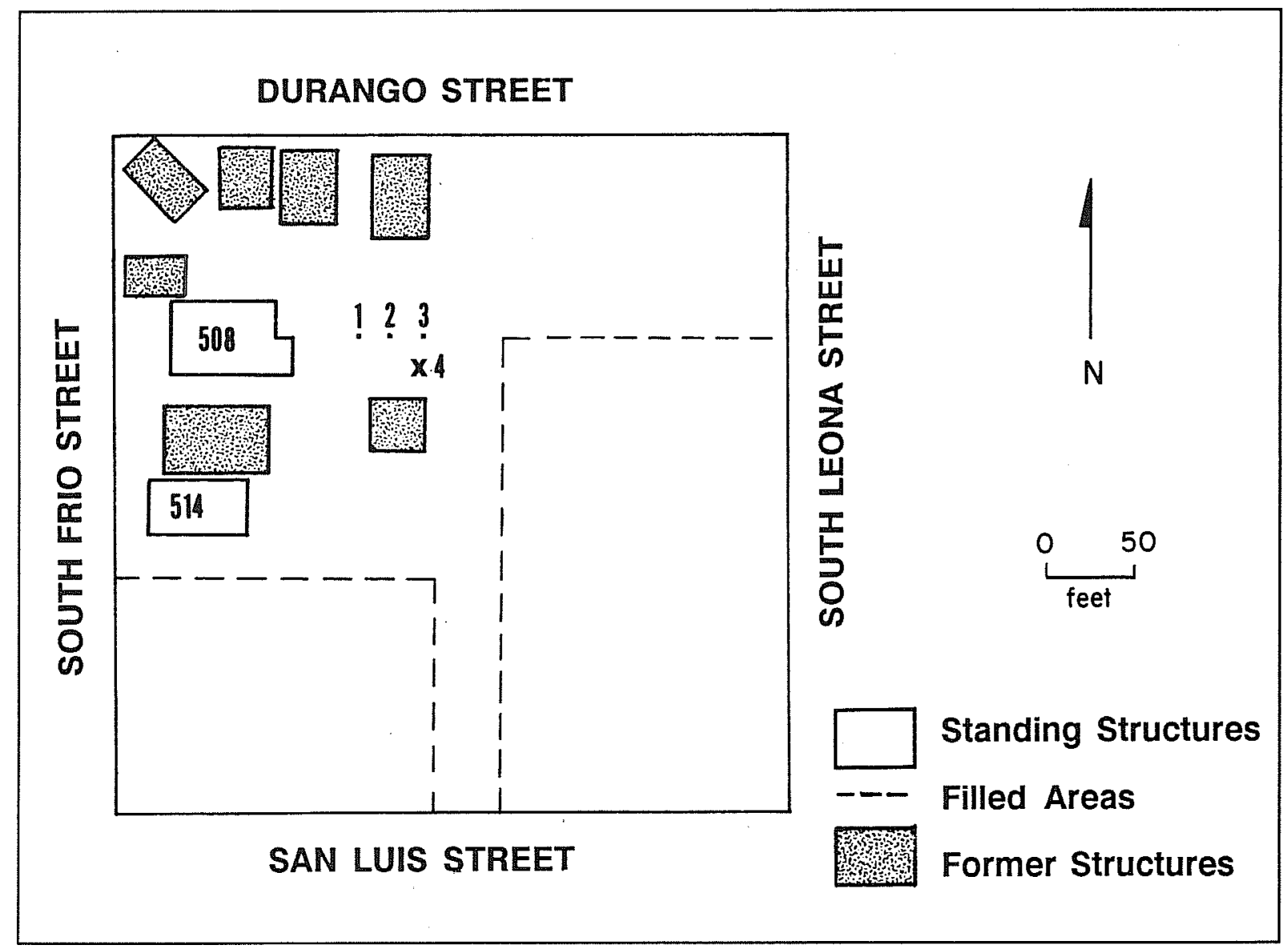

Figure 20. Location of Subsurface Testing Units, NCB 280.

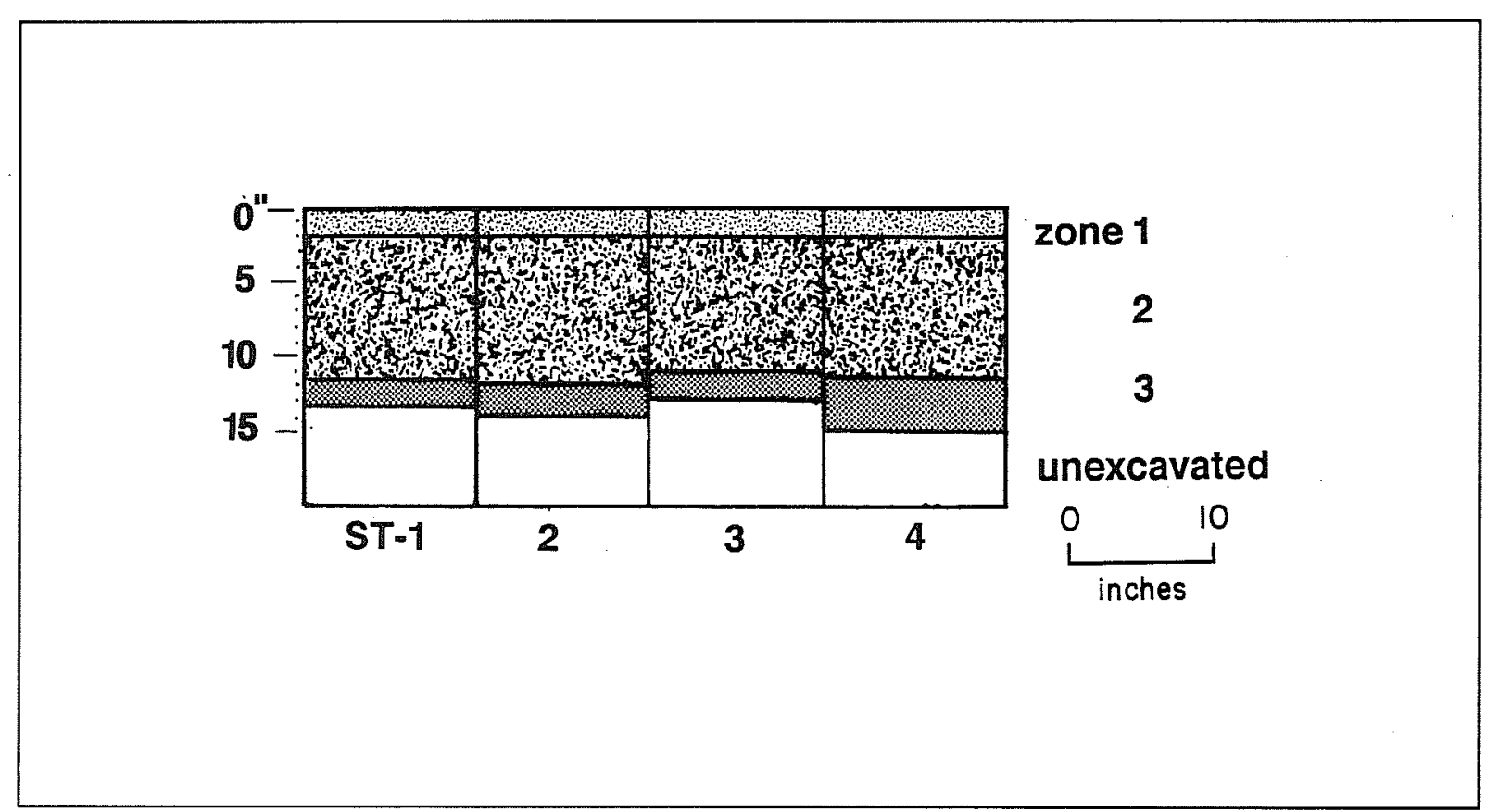

Figure 21. Composite Soil Profile for Shovel Tests 1-4, NCB 280. 
The preliminary report of archaeological investigations of the Vista Verde South project area (A. Fox 1983a:4) pointed out some confusion concerning the dating of the structure at 508 South Frio Street. The 1981 survey report (DeLara-Almond Architects, Inc. 1981) dates the construction between 1883 and 1904. Historical research (Bobbitt 1981:61) showed that George W. Lee purchased this portion of lot 25 in 1894 for $\$ 450$ (BCDR Vol. 127:555), and he was listed in the 1894 city directory (Appler 1894) as residing on the lot. Bobbitt (1981) also states that the present-day structure appears on the 1904 Sanborn insurance map (Sanborn Map and Publishing Company, Ltd. 1904), and, that it may be a remodeled version of the structure listed for Mr. Lee in the 1894 city directory (Appler 1894), but provides no evidence to support such a thesis.

The 1886 bird's eye view map (Koch 1886) of San Antonio shows a residential structure in the approximate location of 508 South Frio Street (Fig. 7) but it does not resemble the structure (or approximate location) indicated on the 1904 Sanborn insurance map. Although the architectural survey did not pinpoint the exact year of construction, it did, however, note that the only identifiable exterior structural alterations were "modern" metal awnings on the porch and front windows (DeLara-Almond Architects, Inc. 1981). In light of the evidence, it would appear that the structure in which Mr. Lee resided in 1894 is not the same structure (or remodeled version) depicted in the 1904 Sanborn insurance map. Archacological investigations could neither support nor deny this thesis.

\section{NCB 281}

One-half of the surface area of NCB 281 was covered by a city park. In 1981, six structures were noted (DeLaraAlmond Architects, Inc. 1981) of which only one (corner of Durango and South Frio Streets) was dated to the Victorian Texas Period (1874-1901); the 1886 bird's eye view map (Koch 1886) depicts this block as vacant (Fig. 7). The archaeological survey crew found no structures remaining on this block. The areas of former structures had been graded and covered with one foot of earthen fill. Surface survey of the southwestern portion of the block failed to identify any deposits or features of archaeological significance.

\section{NCB 282}

NCB 282 had been cleared of all structures at the time of the CAR survey. The architectural survey report (DeLara-Almond Architects, Inc. 1981) notes eight structures; six of which were determined to be of architectural significance. Bobbitt (1981) does not note any structures of historical significance on NCB 282. The 1886 bird's eye view map (Koch 1886) notes a cluster of buildings located in the northwest quadrant of NCB 282 (Fig. 7). The southern half of this block (facing Matamoras Street) once bordered on the Red Light District, as reported in The Blue Book (Anonymous 1911-1912:5; see also Fig. 9).

A mixed surface scatter of historic artifacts (square nails, decorated whiteware ceramics, hand-formed bottle necks) typical of the late 19 th century to early 20 th century was noted in the northwest quadrant of the block. A three-foot-square test pit was laid out in the approximate center of this surface scatter and excavated to a depth of 16 inches. Stratigraphic evidence pointed to subsurface disturbance, presumably due to fill and grading activities related to demolition of previous structures.

Artifacts recovered from this test pit were temporally mixed and represented a variety of human activities: an ink well, whiskey bottle fragments, tin scraps, window glass, kitchen cookware, dining room ceramics, buttons, and a portion of a ceramic doll. The diversity of materials is indicative of a residential trash disposal area. The temporal mixing of the artifacts suggests a secondary deposit rather than a primary (original) context.

\section{NCB 283}

NCB 283 had been cleared and bulldozed of all structures and debris except for a small area around a gas station at 500 Buena Vista Street. The architectural survey noted this structure to be of architectural significance at the state level (DeLara-Almond Architects, Inc. 1981). The National Park Service rejected the nomination of this 
structure to the National Register of Historic Places (National Park Service Form 11593, December 29, 1982) as the structure was "less than 50 years old and did not appear to be exceptionally significant."

The 1886 bird's eye view map (Koch 1886) depicts numerous structures which appear to be residential dwellings on this block (Fig. 7). Surface survey did not locate any foundations or similar features which might be attributable to those noted in 1886 or any deposits or features of archaeological significance.

\section{NCB 301}

NCB 301 had been cleared of all existing structures, with most areas leveled by bulldozing. Traces of structural foundations were still visible in the vicinity of 211 and 213 South Pecos Street. The foundations appear to be from "salt-box" or "settlement style" residential structures. This type of construction usually dates from the middle to late 19th century. They were probably built for Bryan Callaghan, Sr., soon after he acquired the lot in 1850 (Bobbitt 1981:71). Historic artifacts on the surface near the foundations were early-to-middle-1900s ceramics, turn-of-thecentury bottle necks, and early 20th-century construction materials. Several modern concrete slab building foundations were exposed along the southeast quadrant of the block as well. The northeast and northwest quadrants contained numerous piles of fill dirt and several depressions from recent bulldozing activity.

The architectural survey report (DeLara-Almond Architects, Inc. 1981) notes 14 structures for NCB 301; seven were constructed between 1901 and 1930 (FDT Period), six were dated to the Victorian Texas Period (1874-1901), and one was modern. Three of these structures (209, 211, and 213 South Pecos Street) have been determined eligible for nomination to the National Register of Historic Places. (These structures are shown in the appendix as Figures $35, a, b ; 36, a$.

A large surface area was scraped with a backhoe (utilizing the bucket) to search for indications of subsurface features or deposits; none were found. Indications of recent outbuildings (sheds) in the form of wooden posts cut off at ground surface were also noted. A feature which contained a few turn-of-the-century ceramics, cut and wire nails, window glass, and charcoal/cinders was also noted. This feature appears to represent an area where residential trash has been burned.

\section{$\mathrm{NCB} 302$}

NCB 302 had been completely cleared and graded flat, except for Mario's Restaurant on the southeast corner of the block. The architectural survey report (DeLara-Almond Architects, Inc. 1981) notes nine structures; two (425 Matamoras Street and 458 Nueva Street) were dated to the Victorian Texas Period (1874-1901).

Machine grading operations had produced a level surface for most of the block. The original surface (ground surface before leveling and grading operations) was still exposed in the northeast and northwest quadrants. Fill dirt was evident only in the southwest quadrant, and then at a depth rarely exceeding six inches.

The 1886 bird's eye view map (Koch 1886) was consulted to decide which area had the greatest potential for historic remains. This map depicts row houses facing South Pecos Street; the remainder of the block was vacant (Fig. 7). Surface survey of this area failed to identify any discrete loci of artifacts attributable to those structures depicted in the 1886 map.

Survey of the southwest portion of the block yielded the greatest number of historic artifacts. Most all were residential in nature (lead-glazed and ironstone ceramics) and typical of the late 19th to early 20th centuries for this area. Careful examination failed to identify any features or deposits of archaeological significance for the block. 
The DeLara-Almond Architects, Inc. (1981) report notes 10 structures on NCB 303: three were constructed during the Victorian Texas Period (1874-1901), six were dated to the FDT Period (1901-1930), and one was modern. The 1886 bird's eye view map (Koch 1886) depicts this block as being empty.

When the CAR survey team arrived at this block, only four boarded-up structures remained (416 and 420 Matamoras Street and 401 and 411 South Pecos Street). (The four structures are shown in the appendix as Figure 37, a [416 Matamoras Street]; Figure 36,b [420 Matamoras Street]; Figure 37,b [401 South Pecos Street]; Figure 38, a [411 South Pecos Street].) The southern half of the block had been cleared of all structures and was covered with recent fill. The northern half had been cleared except for a paved parking lot and the four structures. The entire block was surveyed, and subsurface testing was concentrated behind 416 and 420 Matamoras Street. Subsurface testing in the vicinity of 401 South Pecos Street (Anton Riecher blacksmith shop) and 411 South Pecos Street (Anton Riecher residence) was not considered feasible due to surface disturbances and the paved parking areas.

Shovel test probes sought to isolate subsurface features such as trash pits and privies behind the structures at 416 and 420 Matamoras Street (Fig. 22). Previous historical research had established that these two structures had been used as brothels around the turn of the century. The structure at 420 Matamoras Street had been owned and operated by Dorothy McNue and was constructed sometime between 1904 and 1913. This two-story wooden structure is rather unique in design in that the second story has over a dozen windows (evenly spaced) of the same dimension; this in all probability is related to the original function of the structure.

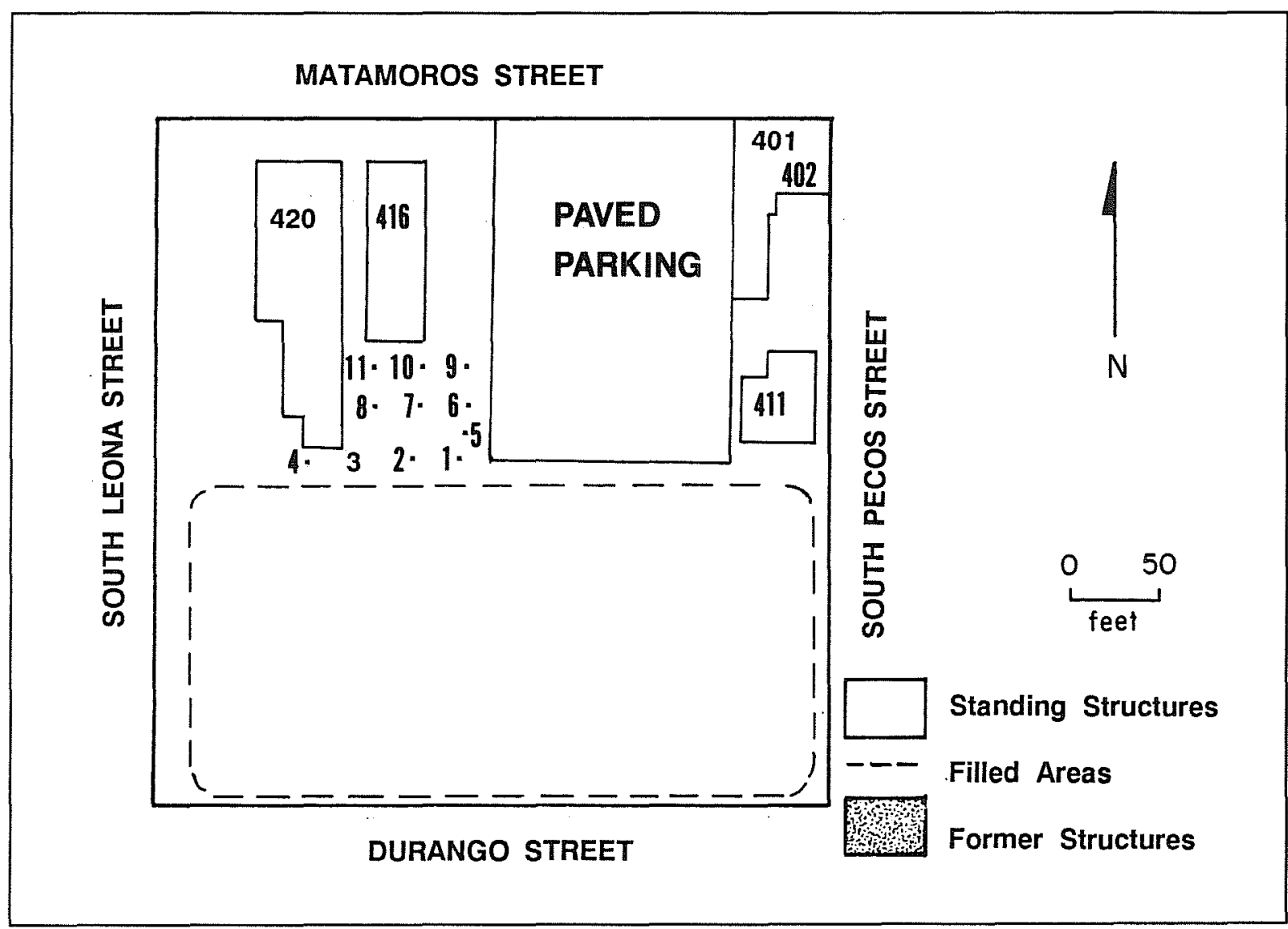

Figure 22. Location of Subsurface Test Units on NCB 303. 
Shovel testing in this area consisted of 11 test probes placed in a grid pattern (Fig. 22). Artifactual materials were limited to the upper 7-10 inches in all shovel tests. The artifacts recovered include construction materials (nails, tile, window glass, fragments of bricks, porcelain insulators, bathroom fixtures), kitchen/dining room ceramics (lead-glazed wares, whitewares, creamwares, glazed earthenwares), and fragments of household furnishings (pressure plug from an electric lamp, light bulb fragments, mirror fragments, and a doorknob).

Comparison of the soil profiles from the shovel tests indicated that little surface disturbance had occurred in this area. Several of the tests had light gray strata but could not be confidently identified as ashen layers or zones related to trash burning. The heaviest concentration of artifacts was recovered from shovel tests 1,2 , and 6 which were near the back property line behind 416 Matamoras Street. In all, 549 items were recovered, all of which are dated post-1900, with many centering around the 1920-1930 time period. Many of the artifacts are residential in nature, but none were directly attributable to the known historical businesses which once operated nearby.

\section{$\underline{\mathrm{NCB} 304}$}

The DeLara-Almond Architects, Inc. (1981) survey report notes 22 intact structures on NCB 304. Two were dated to the Victorian Texas Period (1874-1901); 18 were thought to belong to the FDT Period (Texas in the First Decades of the 20th Century, 1901-1930), and two were modern.

This block contained only one intact structure when the CAR survey team arrived. This former residential structure, located at 508 South Leona Street, had been determined eligible for nomination to the National Register of Historic Places; it has since been rejected for inclusion. The eastern half of this block was covered with recent fill; the western half was overgrown with weeds, bushes, and trees but appeared to be relatively undisturbed.

The entire block was surface surveyed with no subsurface testing. A modern privy (post-1920) was found near the approximate center of the block. The privy contained a variety of artifacts (electrical insulators, pink carnival glass, and a variety of glass fragments); nothing was collected. Previous personal surveys in downtown and west side areas have noted a single privy in the center of a lot with all four sides of the lot containing small, one-story residential structures. This arrangement is locally called a corral. The single privy and a single water spigot were used in common by all the residents of the lot (Anne A. Fox, personal communication).

\section{$\mathrm{NCB} 305$}

The Jose Antonio Navarro Elementary School and associated buildings occupy all of NCB 305 (Fig. 23). This school structure, the first in the city, was constructed in 1885 (Bobbitt 1981:80). The school was in continuous operation until 1975 when the San Antonio Independent School District Board of Education closed it. This school complex was included on the National Register of Historic Places in 1977 (see also DeLara-Almond Architects, Inc., and Bobbitt [1981:80-82] for a history of the school).

\section{$\mathrm{NCB} 306$}

NCB 306 contained 18 intact structures, mostly residences, at the time of the DeLara-Almond Architects, Inc. (1981) survey. The residence at 721 South Pecos Street (Guilbeau-Saldana house) dates to 1855 and has been included on the National Register of Historic Places (see Fig. 39, a in the appendix). It is an excellent example of the "salt-box" style of construction which utilized adobe and wood construction materials. La Trinidad United Methodist Church (constructed in 1886) occupies the northeast corner of the block. Several residential structures were located in the southwest quadrant and were still occupied at the time of the CAR survey; three residences were also still occupied in the southeast quadrant. The structure at 717 South Pecos Street (see Fig. 38,b in the appendix), constructed ca. 1909 (DeLara-Almond Architects, Inc. 1981), has been determined eligible for nomination to the National Register of Historic Places. Surface survey of accessible portions of the block failed to identify any features or deposits of archaeological significance. 


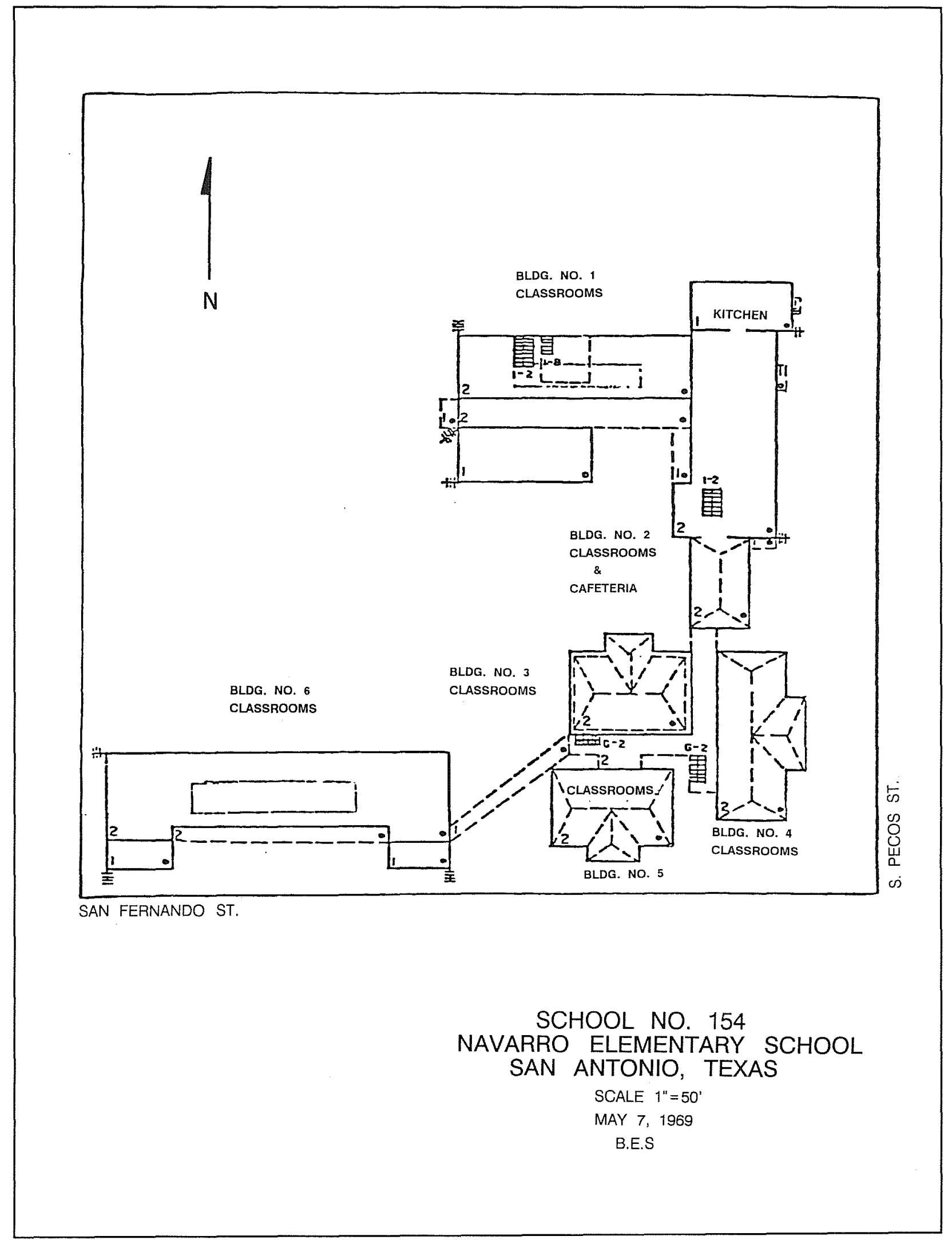

Figure 23. Jose Antonio Navarro School Complex on NCB 305. 


\section{NCB 307}

The DeLara-Almond Architects, Inc. (1981) survey report notes 19 intact structures on NCB 307. The oldest of these, located at 310 El Paso Street, was a one-story stone masonry house constructed in 1869, during the Reconstruction Period (1865-1874). This building was not considered to be eligible for nomination to the National Register of Historic Places and is at present falling apart from neglect and vandalism. The DeLara-Almond Architects, Inc. (1981) report classifies six structures as belonging to the Victorian Texas Period (1874-1901) and the remainder as dating to the early 20 th century.

One structure of particular interest, located at 801 South Pecos Street (see Fig. 40,a in the appendix), is the Louis Rummel house which was constructed sometime after 1855. This structure appears on the 1886 bird's eye view map (Koch 1886) of San Antonio and is among the oldest buildings in the Vista Verde South project area; it has been determined eligible for nomination to the National Register of Historic Places (see also DeLara-Almond Architects, Inc., and Bobbitt [1981:91-92] for historical background). Surface survey of accessible areas failed to identify any materials or features of archaeological significance.

\section{NCB 308}

The DeLara-Almond Architects, Inc., survey report notes seven intact structures on NCB 308; one was dated to the Victorian Texas Period (1871-1901). When the CAR survey team arrived it had already been demolished and the lot cleared. The northwest quadrant of the block was occupied by commercial business structures which were still in operation, and four residential structures were still occupied in the southeast and southwest quadrants. Approximately $50 \%$ of the block had been cleared, and most of it was overgrown with tall weeds and bushes. This area was also littered with an incredible amount of "modern" trash, beer bottles/cans, old mattresses, and scrap lumber which had been dumped in large piles.

Survey of this block was limited to surface examination which failed to identify any materials or features of archaeological significance.

\section{NCB 879}

The 1981 survey report (DeLara-Almond Architects, Inc. 1981) makes comment on several small structures which were "representative of the many found in this block." All structures had construction dates between 1901 and 1930. Those areas without structures were covered by approximately six inches of gravel, modern structural debris, and/or recent domestic trash. Surface testing of accessible areas (less than $25 \%$ of the block) in and around the remaining structures failed to identify any materials or features of archaeological significance.

\section{NCB 880}

The general condition of NCB 880 did not lend itself to surface survey; most of the block was covered by operating commercial businesses with all other areas covered by gravel paving. This block did, however, contain a well-maintained Mission Revival style brick building with a Spanish tile roof (it has not been considered to be eligible for nomination to the National Register of Historic Places).

\section{NCB 881}

The general condition of NCB 881 was the worst of all the blocks surveyed by the CAR team. The entire block amounted to a scrap metal junkyard which had undoubtedly served as the dumping ground for local businesses. All surface areas visible evidenced extensive disturbance; survey was not practical. 


\section{ARTIFACT ANALYSIS}

Subsurface testing and pedestrian survey of the Vista Verde South project area produced a variety of historic artifacts (Table 2). Recovered materials from each block, subsurface test unit, and isolated surface find were bagged and catalogued individually. All materials are currently stored at the CAR-UTSA facilities.

The research design for this project called for testing to determine the location, depth, and areal extent of artifact deposits with National Register potential. Recovered materials are therefore representative for each particular area only; generalizations or hypotheses above this level are difficult at best due to the nature of the research design (testing rather than data collection). Controlled excavation of identified artifact scatters and possible midden areas at some future date may produce a sufficient data base to allow for larger interpretations than are possible at present. Descriptive analysis was therefore chosen as it would provide the most useful results for future studies.

TABLE 2. MATERIALS RECOVERED DURING THE VISTA VERDE SOUTH PROJECT AREA SURVEY

\begin{tabular}{|c|c|c|c|c|c|c|c|c|c|c|c|c|}
\hline & $\begin{array}{l}\text { NCB } \\
237\end{array}$ & $\begin{array}{l}\text { NCB } \\
266\end{array}$ & $\begin{array}{l}\text { NCB } \\
276\end{array}$ & $\begin{array}{l}\mathrm{NCB} \\
278\end{array}$ & $\begin{array}{l}\text { NCB } \\
280\end{array}$ & $\begin{array}{l}\text { NCB } \\
282\end{array}$ & $\begin{array}{l}\text { NCB } \\
283\end{array}$ & $\begin{array}{l}\text { NCB } \\
301\end{array}$ & $\begin{array}{l}\text { NCB } \\
302\end{array}$ & $\begin{array}{l}\text { NCB } \\
303\end{array}$ & $\begin{array}{l}\text { NCB } \\
878\end{array}$ & Total \\
\hline Kitchen Ceramics & 6 & 2 & 7 & 3 & 18 & 12 & 1 & 23 & 4 & 104 & 2 & 182 \\
\hline Kitchen Glass & 3 & 2 & 29 & 3 & 340 & 16 & 1 & 27 & 3 & 177 & 2 & 603 \\
\hline Other Glass & 0 & 2 & 0 & 0 & 128 & 2 & 0 & 1 & 0 & 39 & 1 & 173 \\
\hline Household Furnishings & 0 & 0 & 0 & 0 & 14 & 0 & 0 & 0 & 0 & 5 & 0 & 19 \\
\hline Clothing & 0 & 1 & 0 & 1 & 29 & 0 & 0 & 0 & 0 & 11 & 6 & 48 \\
\hline Personal Items & 0 & 0 & 0 & 0 & 7 & 2 & 0 & 0 & 0 & 2 & 1 & 12 \\
\hline Activities & 0 & 0 & 1 & 2 & 5 & 1 & 1 & 4 & 3 & 6 & 0 & 23 \\
\hline Barn/Workshop & 0 & 1 & 5 & 0 & 87 & 7 & 0 & 3 & 0 & 13 & 13 & 129 \\
\hline Construction & 0 & 7 & 41 & 3 & 162 & 25 & 0 & 36 & 1 & 144 & 9 & 428 \\
\hline Miscellaneous & 0 & 0 & 3 & 0 & 0 & 0 & 0 & 0 & 0 & 11 & 0 & 14 \\
\hline Total & & & & & & & & & & & & 1631 \\
\hline
\end{tabular}

\section{DATING ARTIFACTS}

Prior to the 1960s, historic archaeology usually involved 17th-century and 18th-century sites such as Jamestown, Williamsburg, Fort Michilimakinac, and Louisburg. In almost every case, investigations were limited to sites and areas associated with important people, places, or events.

Detailed chronologies have been developed based on the observable differences in shape, style, form, decoration, and material of recovered artifacts from these and other sites (Blumstein 1966; Robinson 1971; United States Department of Commerce, National Information Service 1978). The utility of such chronologies cannot be over emphasized; certain artifacts can now be used as temporal markers by which to date historic deposits. For example, English transferware patterns on whiteware ceramics were being produced in quantity for export around 1800 (John Smith, personal communication), thus providing a date before which they could not have appeared in the United States.

The earliest known type of nail in San Antonio was the Spanish hand-made/forged nail which was common until the early 19th century. Cut nails (machine cut from sheets of metal) became the standard during the middle-tolate 19 th century; these nails are also referred to as square nails. By the $1890 \mathrm{~s}$, wire nails (machine cut from long 
pieces of wire) became locally available. The wire nail may have reached San Antonio as early as the 1880 s, brought here by the U.S. Army supply shipments from the east (Anne A. Fox, personal communication).

Archaeological investigations at historic sites in or near San Antonio have produced a great variety of artifacts which have been used to develop local chronological sequences which span the 250-year history of the city. Artifacts are generally grouped according to historic periods: Spanish colonial (1731-1836), pre-Civil War (Texas Republic 1836-1846), Lone Star state (1846-1861), Civil War (1861-1865), Reconstruction (1865-1874), Victorian Texas (1874-1901), and 20th century (1901-present).

Much of the data for the Spanish colonial period (1731-1836) has been obtained from controlled archaeological testing and excavation at such local sites as the Alamo (Fox, Bass, and Hester 1976; Eaton 1980; Fox and Ivey n.d.), the Spanish Governor's Palace (A. Fox 1977), and La Villita Historic District in downtown San Antonio (Labadie, assembler 1986; Labadie 1986). Work conducted by the CAR-UTSA at the five local Spanish missions (Fox and Hester 1976; A. Fox 1981; Ivey n.d.; Hafernik and Fox 1984; D. Fox 1979) and Rancho de las Cabras in Wilson County (Ivey and Fox 1981; Ivey 1983; Jones and Fox 1983; Taylor and Fox 1985) have provided further archaeological evidences for the Spanish colonial period in San Antonio. Among the most diagnostic artifacts for this period are ceramic and pottery sherds. Characteristic of this period are the soft paste, tin-enameled (majolica) styles (tan, brown, blue-on-white), yellow and greenish lead-glazed earthenwares, Indian Goliad ware pottery (D. Fox 1983:87), and French tin-enameled (faience; yellow, brown, red-on-white) styles (Tunnell and Ambler 1967). No artifacts attributable to the Spanish colonial period were identified by this survey of the Vista Verde South properties.

Archaeological evidence for occupation during the early and middle 19th century at San Antonio sites has been difficult to identify amidst the complexity of remains of earlier and later occupations (D. Fox 1983:120). Few local archaeological sites have been found that were occupied exclusively during the time of the Revolution and Republic period (1836-1846; ibid.). Most of the more important investigated sites for these periods are located outside the San Antonio area: Fort Lipantitlan, on the lower Brazos River near San Patricio County (Ing 1976), the Sutherland Plantation in Jackson County (Freeman and Fawcett 1980), Washington-on-the-Brazos (Davis and Corbin 1967), and the French Legation Building in Austin (Olds 1967). These sites and others have yielded material evidences (ceramics, glass, metal objects) for which the dates of manufacture and function(s) have been established. Much information has been gathered for items postdating the 1820s. Spanish colonial period ceramics were being replaced by the harder, more consistently shaped, clear-glazed white paste earthenwares and pearlwares which were being imported in large quantities to Texas Gulf ports (D. Fox 1983:139). The English ceramic wares have been previously described in detail by Godden (1964, 1967), Davis and Corbin (1967), and Mankowitz and Haggar (1975). English wares exhibit a variety of surface decorations (mocha ware, sponged, spatter, transfer, decal, hand painted). In general terms, it is difficult to pinpoint the exact date for the introduction of a particular design or pattern for English wares. They are most commonly described in the archaeological literature as being either preCivil War (1820-1861) or post-Civil War. No English wares attributable to the pre-Civil War period were identified by this survey of the Vista Verde South properties.

During the mid-18th century, major changes in glass artifacts began occurring. Machine-made glass containers began replacing the traditional mouth-blown vessels. Machine-produced glass containers often have marks which are related to a particular type of machine used in the production of the vessel (Miller and Sullivan 1981). Estimates of relative age can be deduced based on observations of such things as pontil marks (scars on the bottom of the vessel produced by the metal rod which held the vessel while forming the neck), embossed lettering, applied lips, mold seams, screw tops, and glass thickness. The range and variation in the neck length, diameter, glass thickness, and shape are also related to the particular type of machine that makes the item (which was determined by the intended function of the vessel). A general guide applicable to glass artifacts that concentrates on observable differences is presented in Figures 24 and 25 . Known patent dates for machines, processes, and styles can also aid in providing a general framework by which to establish an initial date for a particular artifact (Table 3). For instance, the Ball jar or Mason jar was first patented in 1858 (Stephens 1979:31). During the late 19th century, machine-produced glass containers provided the vehicle for the widespread usage of patent medicines and bitters. The construction of these containers (thick-walled and thick-rimmed) was such that many have survived to the present with little or no damage or breakage. It was a common practice to order these medicines and cures from mail order catalogues (Montgomery Ward and Co. 1895:260; Israel 1897:31-44; Sears, Roebuck and Co. 1902:441460). 


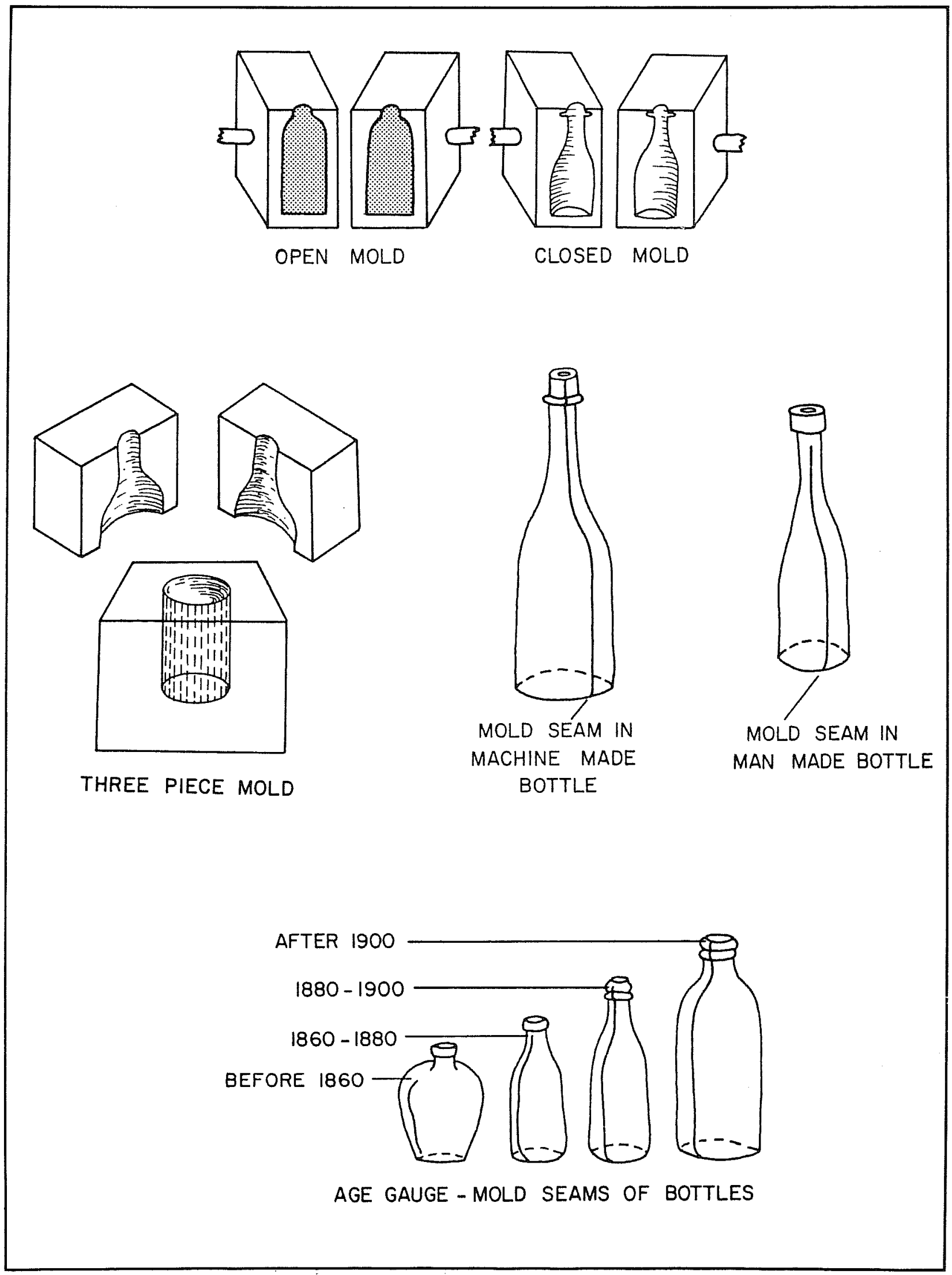

Figure 24. Estimating Age of Glass Containers Using Mold Seams. From Kendrick (1966). 


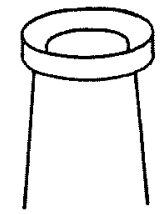

A

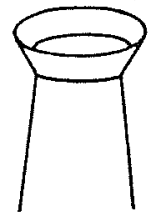

A

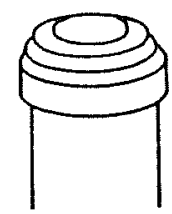

B
A Prescription

B Champagne

C Brandy

D Beer

E Bead

F Double Bead

G Patent/Extract

H Wide Mouth

Patent/Extract

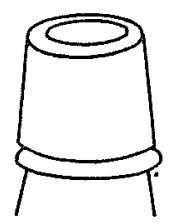

C

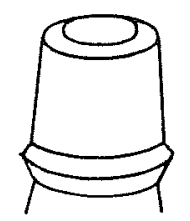

C

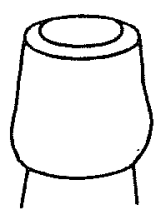

D

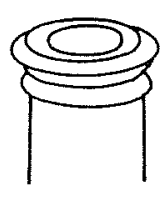

F

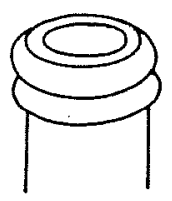

F

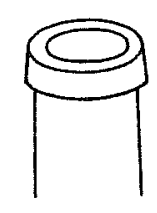

G<smiles>CC1CC2CCC(C2)C1C</smiles>

K

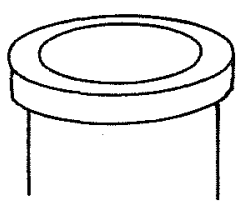

H

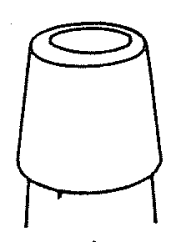

I

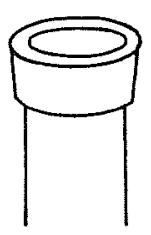

J
1 Oil

$J$ Packing

K Crown

L Club Sauce

M Screw

N Sheared

E

$\mathrm{F}$

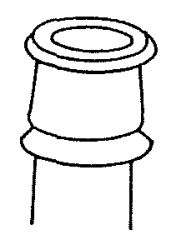

L

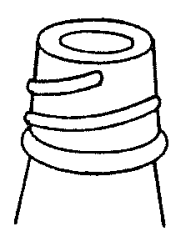

M

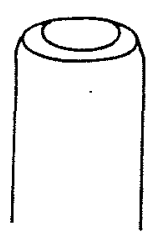

N

Figure 25. Glass Container Rims and Necks With Known Historical Functions. From Wilson (1981:111). 
TABLE 3. DATES FOR KNOWN HISTORICAL CHANGES

IN GLASS CONTAINER MANUFACTURE

\section{DATE MANUFACTURING CHANGES}

ca. 1810 Three-piece hinged bottle mold introduced

1810 Appert discovers how to preserve foods for storage, uses glass jars and bottles with wired-on cork stoppers

ca. $1820 \quad$ First historical flasks

ca. 1825 Octagonal medicine bottles, later followed by oval shapes, tooled lips

1827 Pressing mold machine patented

$1827-1850$

1830

Period of lacy pressed glass patterns

ca. 1840

before 1850

after 1850

1858

1850-1880

$1860 \mathrm{~s}$

1861

No Masonic pictorial flasks after this date

Two-piece hinged bottle mold

Lipping tool for finishing bottles (Ferraro and Ferraro 1961) is dated 1850-1860, but I have seen earlier bottles finished with a lipping tool.

Very little crown (flat) glass produced after this in U.S.

Mason jar patented

Glass balls for trap shooting

Kerosene lamps appear

First lead glass medicine bottles. Shortly after this "French squares" - tall, four-sided bottles with beveled edges - were put on the market.

$1867 \quad$ First lettered panel bottles

1860-1900

after 1868

ca. 1870

after 1870

1871

1872 or 1879

1873

1879

1881

1882

Heyday of bitters (patent medicine) craze

Most figure bottles are post-Civil War

Chilled iron mold introduced

Historical flasks are rare.

Pressed glass bottle fire extinguisher patented

Hutchinson stopper patented

U.S. patent for internal glass ball is stopped. (Patented in England in 1860.)

Edison's first light bulb - hand blown

Semiautomatic bottle machine

Lightening fastener patented in U.S.

Mid 1880s

First milk bottles

1892

Crown caps for bottles patented

1891-1893

Safety glass with embedded wire mesh produced

1903

Owens automatic bottle machine patented

Source: Lorrain (1968)

Among the more important historic sites in San Antonio which date to the mid-to-late 19th century are the Dolores Aldrete House (Fox, Valdez, and Bobbitt 1978), the Gresser House (Ivey 1978a), the Arciniega Street area on the southern edge of La Villita (Katz 1978), the Mayer House (Ivey 1978b), the Wulff House (Clark 1974) in the King William Historic District, and La Villita Earthworks site (41 BX 677; Labadie, assembler 1986; Labadie 1986).

The majority of the Vista Verde South artifacts date to the late 19th century and early-to-mid 20th century. These materials are consistent with others that have been found in previously investigated late 19th-century sites in San Antonio. Nearly all materials reflect behaviors associated with residential activities.

Due to the small sample size (Table 2), presentation of these materials is limited to the most diagnostic artifacts recovered. Examples of these and the various material classes are also presented. 


\section{RECOVERED ARTIFACTS}

\section{CERAMICS}

Ceramics or pottery are made of clay and have been shaped and fired. The basic ingredients, the manner of mixing them, and the temperature at which they are fired account for the differences in texture, color, and to some degree, shape. Ceramics range from being a basic necessity to a high status luxury good (Miller 1980:2). Analysis of ceramics according to their form and surface decoration (the basic determinates of an object's cost) may, in some instances, allow for inferences relating to social class and ethnicity.

Ceramics are divided into porcelains, earthenwares, and stonewares based on the coarseness of the materials used in the paste and the temperature at which they are fired; porcelains are the finest-stonewares are the coarsest. Each of these broad categories is subdivided according to wares. Porcelains are divided into hard paste, soft paste, or bone china. Earthenwares and stonewares are divided and classified according to observable differences in paste, decoration, and glaze (lead, tin, salt).

The ceramics recovered from the Vista Verde South survey were organized according to ware types in an effort to establish the temporal range of materials from a particular property. Implications of social class, status, and ethnicity were difficult at best, due to the small sample size.

\section{Pearlware}

Pearlware is of early 19th-century English origin (Miller 1980:2). It is typically white in color with a slight pearlescence, produced by the addition of cobalt during manufacture. Subclassifications are based on the method of surface decoration. Several mid-to-late 19th-century hand-painted (Fig. 26,a) and sponged types (Fig. 26,b) were among the sherds recovered. The sponged effect was produced by applying paint with a sponge; disks of cut sponge were used to produce more formal patterns (Anne A. Fox, personal communication). Pearlwares began appearing in the San Antonio area with European settlers prior to the Civil War.

\section{Whiteware}

Whiteware is of English origin, developing out of pearlwares which had originated from creamwares by the $1789 \mathrm{~s}$ (Miller 1980:2). The invention of whiteware is not attributable to a single potter or company, and there is no fixed date for its introduction in the United States or Texas (ibid.:16). Subdivisions based on the method of surface decoration for the sherds recovered during this survey are hand-painted transfer (Fig. 27,m), decal (Fig. 27,q,r), application of a decal over the glaze, molded (Fig. 26,l), use of a mold to produce a textured pattern or design, and flow blue (Fig. 26,j). All whiteware sherds appear to be post-Civil War in date.

\section{Yellow Ware}

Yellow wares are produced, and sometimes decorated or glazed, by essentially the same methods as white or creamwares. The basic difference is the yellow paste, a product of mineral/chemical additives mixed into the paste before firing which produces the distinctive yellow color. Yellow ware has not been proven to be the invention of a single potter or company and enjoyed wide middle class popularity in the late 19th and early 20th centuries. A single sherd from a yellow ware plate was recovered during this survey (Fig. 26,h). 
Ironstone

Ironstone ceramics are much like whitewares except that they have a much harder paste. Several examples of late 19th- to early 20th-centuries sherds from tableware plates were recovered during this survey (Fig. 26,f,g).

\section{Stoneware}

Stoneware has a relatively hard paste which includes additives of sand or silica, producing a coarse texture. Surface decorations include salt and Bristol glazes and slip glazes. Stonewares were typically used on an everyday basis, were relatively inexpensive, and could be found in nearly every kitchen during the late 19th to early 20th centuries in San Antonio (Fig. 27,p).

\section{$\underline{\text { Porcelain }}$}

Porcelain is made from a fine, hard, white paste and is typically translucent. Porcelains, by virtue of their cost relative to whitewares, yellow wares, etc., can be considered as indicators of social class or status if found in a secure context in relatively high proportions to other wares in a historic site (i.e., the French Legation Building in Austin). The inference of social class is based on the relative cost of porcelains to whitewares, yellow wares, etc. No firm conclusions of this type can be drawn from the porcelain sherds (Fig. 27,s) recovered during this survey, due principally to the sample size.

\section{Mexican Lead-Glazed Ware}

Mexican lead-glazed wares are produced by traditional Mexican pottery methods and have widespread variation in surface texture, design, and coloration. They can be used to infer social class as well as ethnicity if found in high proportionate frequencies. Again, sample size prohibits any firm conclusions based on the recovered sherds from this survey. Several different sherds of late 19 th- to early 20 th-centuries vintage were recovered (Fig. $27, \mathrm{i}, \mathrm{k}, \mathrm{m}$ ).

\section{GLASS}

Artifacts made of glass were grouped according to their intended function. Utilitarian vessels are beverage bottles (Figs. 28,b; 29,i), food containers (Figs. 28,e,f; 29,h), and medicine bottles (Figs. 28,a,d; 29,d,e). Nonutilitarian vessels are cosmetic bottles, perfume bottles (Figs. 28,c; 29,c), and nail polish bottles. Construction and household glass items are window glass, light bulbs, and glass lamp chimney fragments. Other glass bottle necks recovered but not identifiable as to function are shown in Figure 29,a,b,f,g. The largest number of glass fragments were unidentifiable. Many of the fragments were either too small or too nondescript to classify.

The earliest datable glass vessel (Fig. 28,f) is identical to one found at Fort Union, New Mexico, which was dated 1880-1885 (Wilson 1981:84). Nearly all the glass artifacts were produced by machine-made processes common during the late 19th and early 20 th centuries.

\section{BUTTONS}

A variety of buttons were among the few items of personal clothing recovered from the Vista Verde South properties. Most were produced by machine and date to the early 20 th century. Several handmade and hand-drilled shell buttons (Fig. 27,e,f) may date to the mid-to-late 19th century. Bone (Fig. 27,a,l), glass (Fig. 27,b-d,g-i), wood (Fig. 27,j), and porcelain (Fig. 27,k) buttons were also recovered. 
Figure 26. 19th-Century Household Ceramic Fragments.
a, hand-painted pearlware (ca. mid-19th century);
b, sponged pearlware (ca. mid-19th century);
c, transfer on whiteware (ca. mid-to-late 19th century);
d, sponged ironstone (ca. late 19th century);
e, hand-painted ironstone (ca. mid-to-late 19th century);
f,g, ironstone with maker's mark (ca. late 19th century);
$\mathrm{h}$, yellow ware plate (ca. late 19th century);
i, Mexican lead-glazed flowerpot (n.d.);
$\mathrm{j}$, flow blue on whiteware (ca. mid-to-late 19th century);
k, Mexican lead-glazed flowerpot (n.d.);
1, molded whiteware (ca. early 20th century);
m, Mexican lead-glazed bowl (ca. late 19th-early 20th centuries);
$\mathrm{n}$, blue willowware on porcelain (ca. late 19th century). 

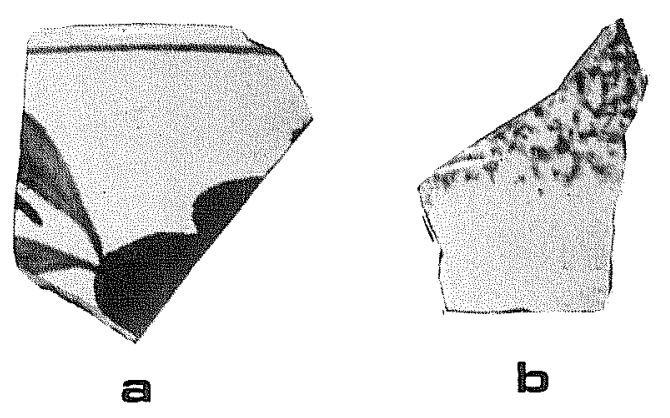

b

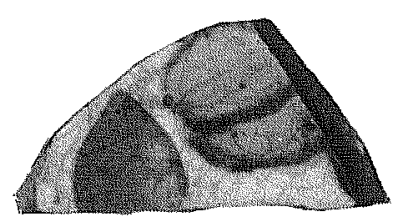

e

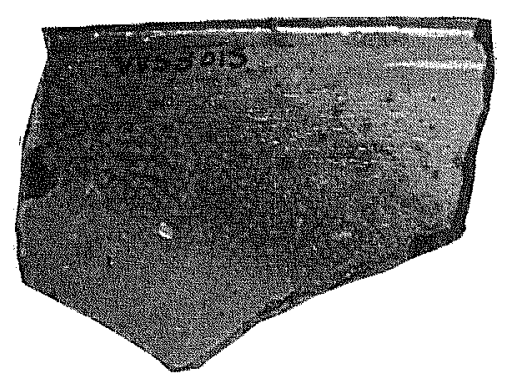

i
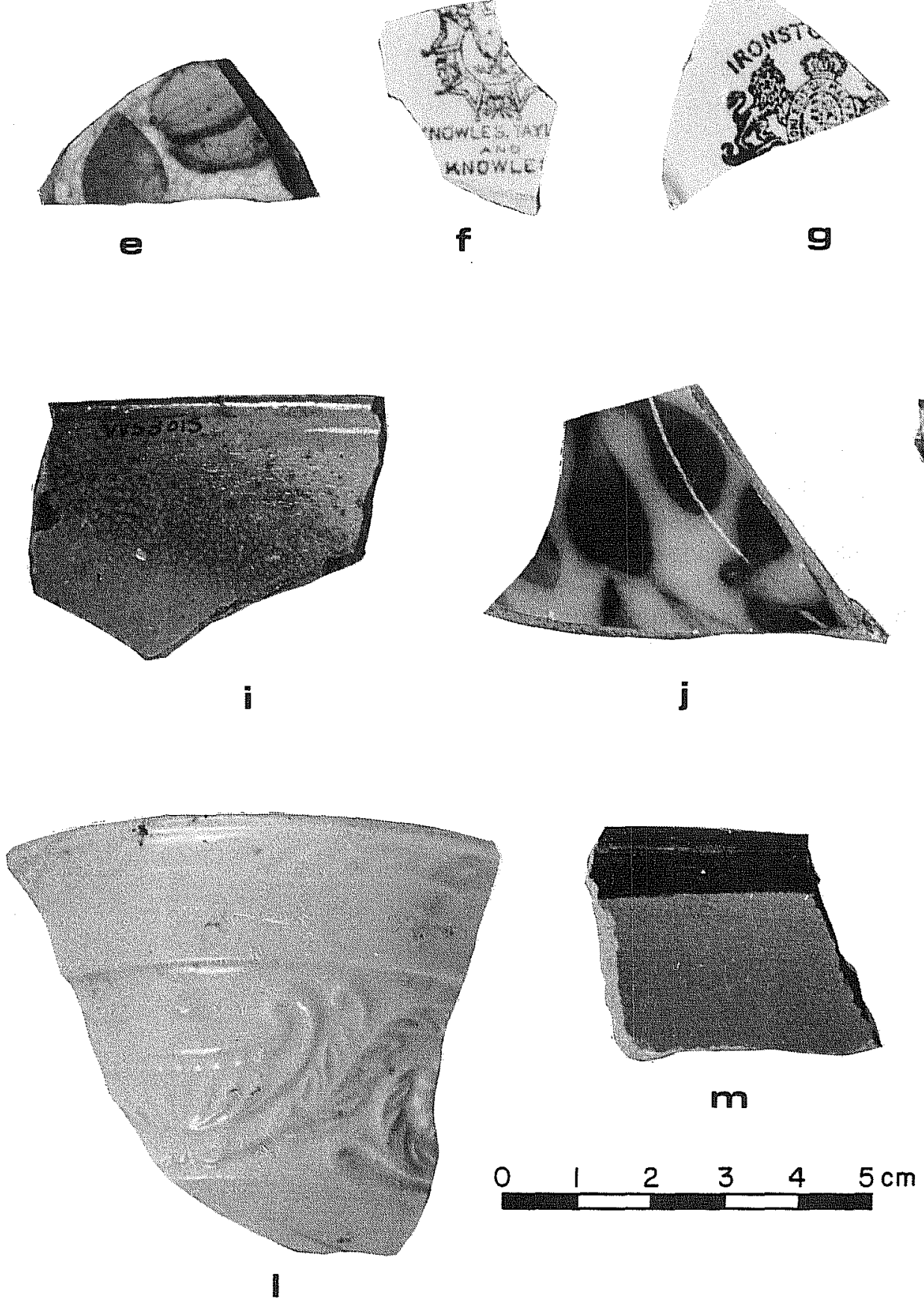
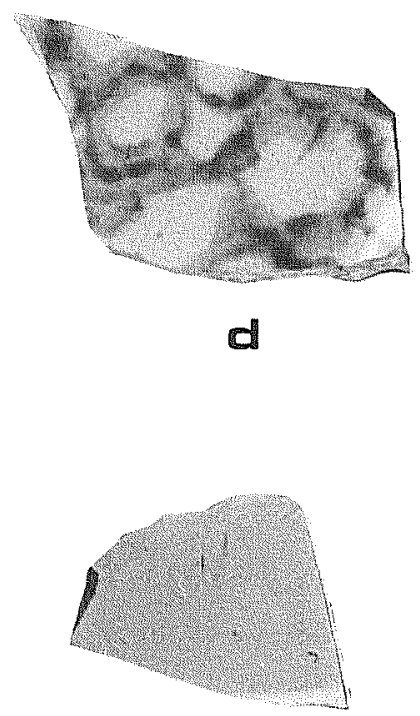

$\mathrm{n}$

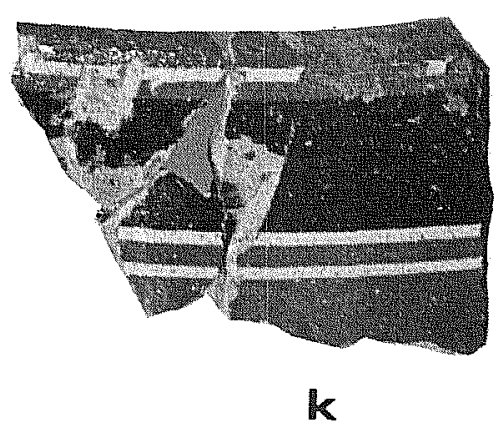


Figure 27. 19th-Century and 20th-Century Buttons and Household Ceramics.
a, two-holed button made of bone;
b-d, two-holed buttons made of glass(?);
$\mathrm{e}, \mathrm{f}$, two-holed buttons made of shell;
$\mathrm{g}-\mathrm{i}$, four-holed buttons made of glass(?);
$\mathrm{j}$, four-holed button made of wood;
$k$, four-holed button made of porcelain;
1, four-holed button made of bone;
m, hand-painted transfer on whiteware (ca. post-1900);
n, blue stripes on whiteware (ca. post-1900);
o, plain yellow glaze on whiteware (ca. early 20th century);
$\mathrm{p}$, black-on-gold glaze on stoneware (ca. mid-20th century);
q, decal on whiteware with gold rim (ca. early 20 th century);
$r$, decal on whiteware (ca. early 20th century);
$\mathrm{s}$, decal and hand-painted porcelain (n.d.). 

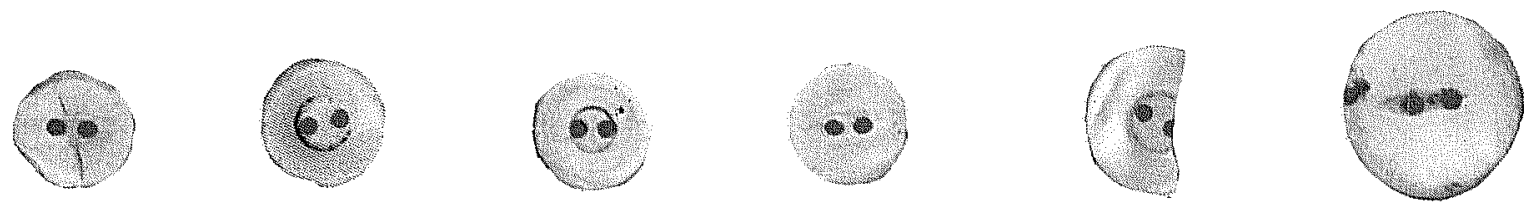

a

b

c

d

e

$f$
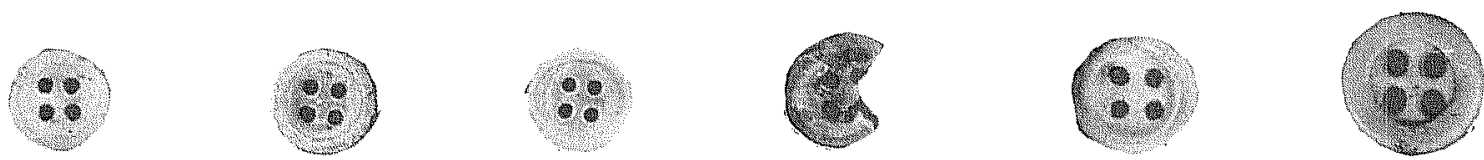

g

h

i

j

k

I

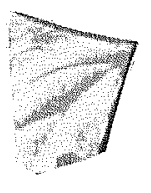

$m$

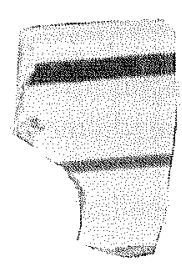

n

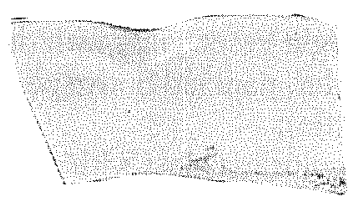

$\mathbf{0}$
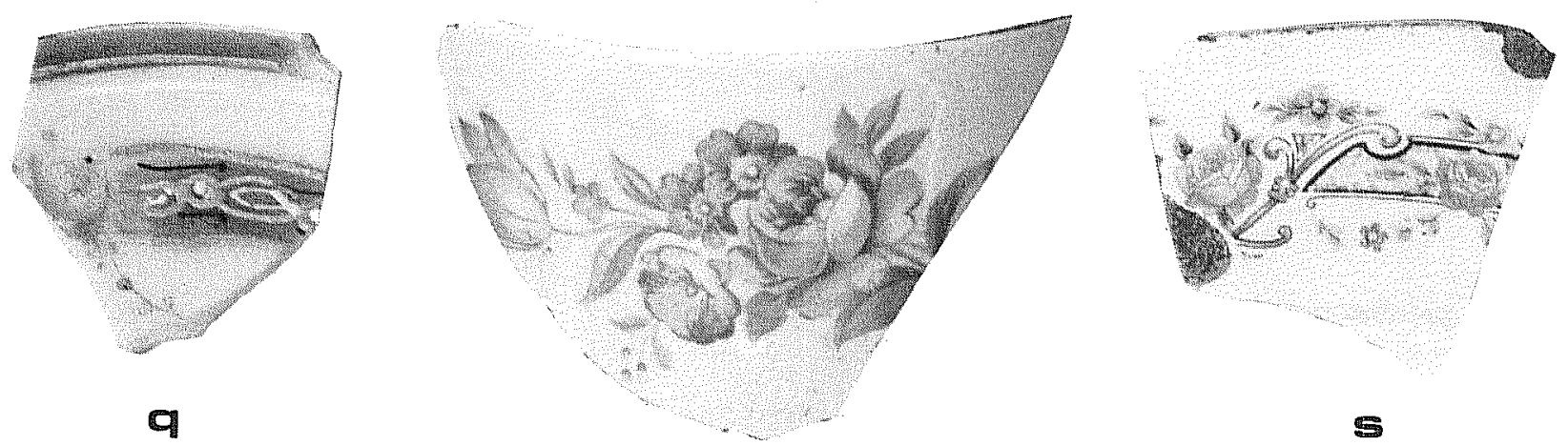

$p$ 
Figure 28. Late 19th-Century Bottles and Bottles Necks.

a, transparent, light green glass with flanged lip neck finish (possible patent medicine or extract bottle);

b, transparent, colorless glass with plain lip neck finish with a single ring below (possible beverage bottle);

c, transparent, colorless glass with a thickened, plain-lip neck finish on a cylindrical body (perfume bottle; Wilson 1981:73);

d, transparent, light green glass with thickened, flanged lip on a rectangular, paneled body (possible patent medicine or extract bottle);

e, transparent, colorless glass with double rounded collar on a rectangular body (possible extract bottle);

f, transparent, light blue glass. The neck finish has a double rounded collar. Molded with an inscription on a rectangular body which reads E. R. DURKEE \& CO., NEW

YORK (sauce bottle dated 1880-1885; Wilson 1981:84). 

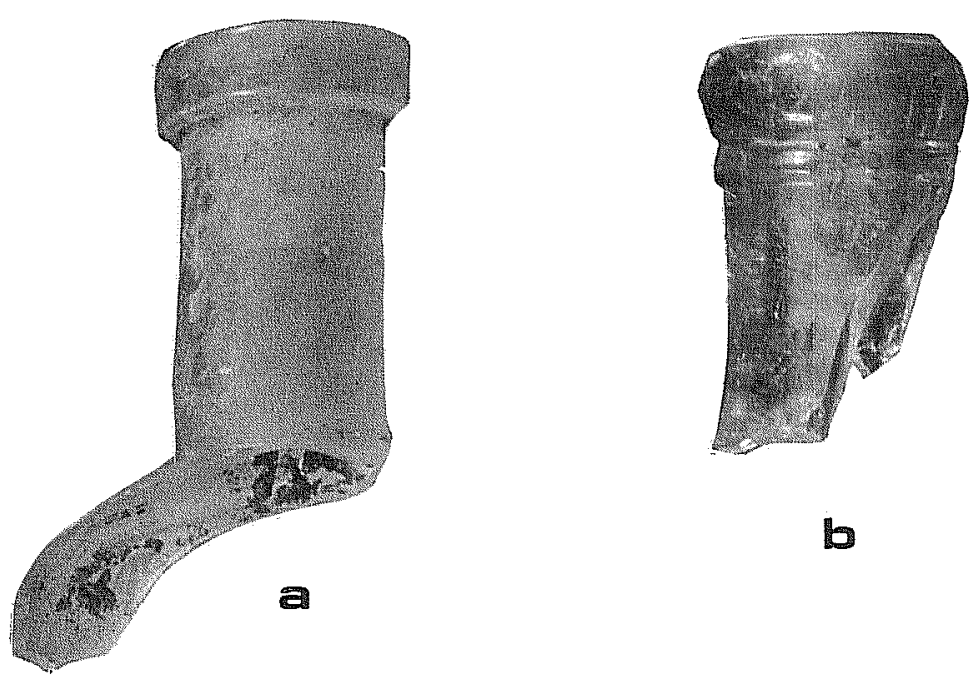

b
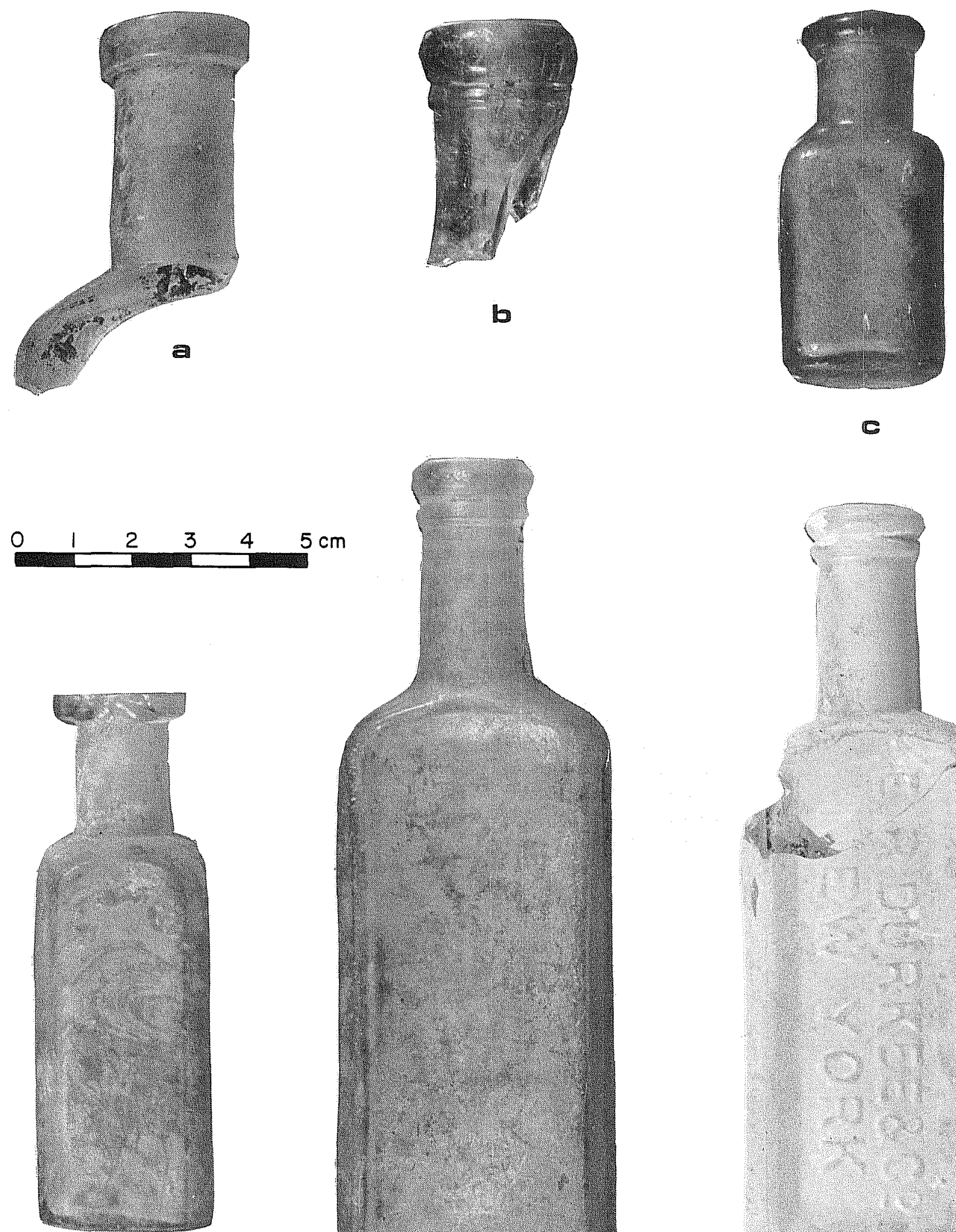

d
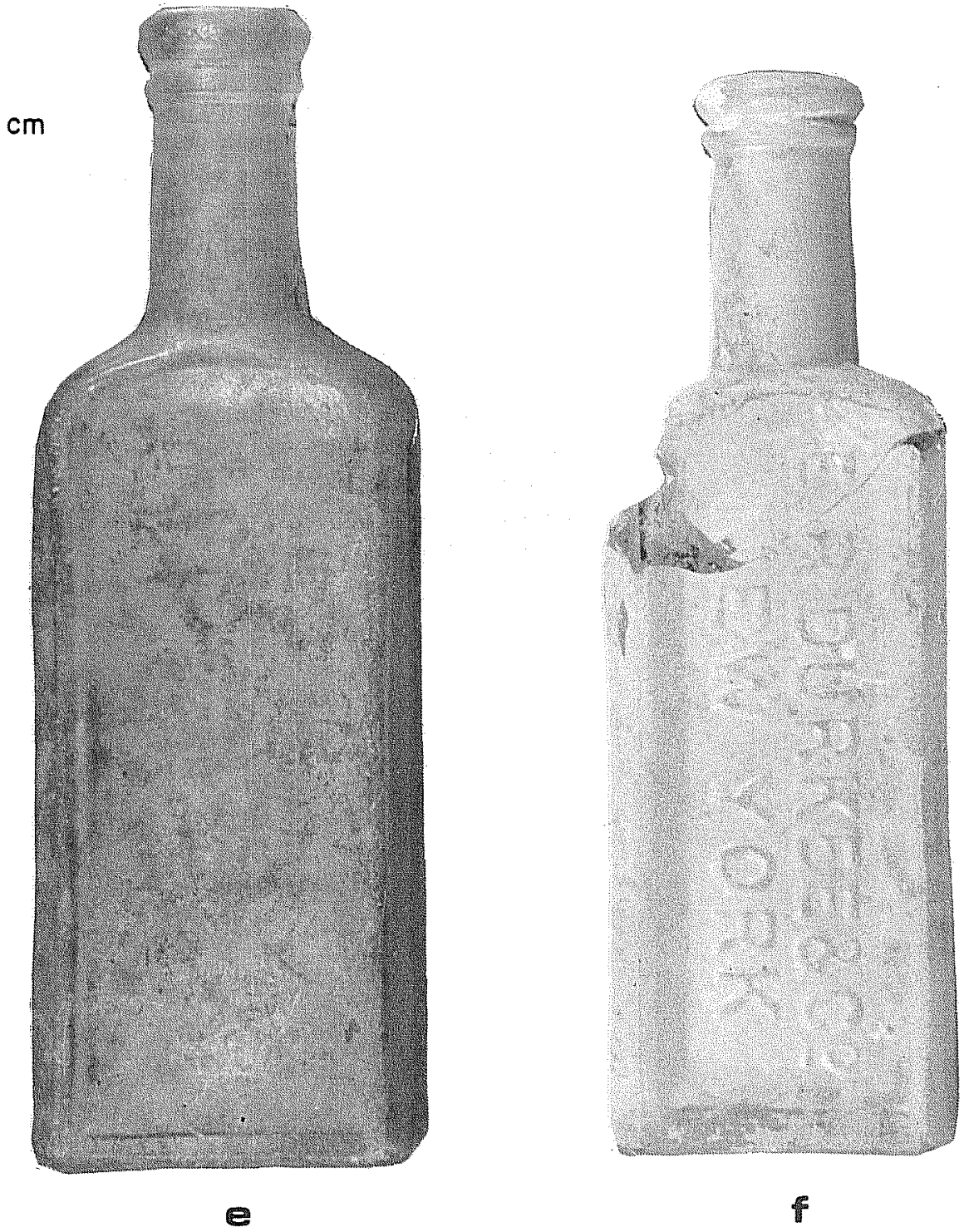
Figure 29. Range and Variation of Bottle Necks Recovered.

a, transparent, colorless glass with thickened neck finish;

b, semitransparent, green glass with crown neck finish;

c, transparent, light green glass with thickened, plain lip neck finish (possible perfume bottle; Wilson 1981:Fig. 247);

$\mathrm{d}$, transparent, light green glass with prescription lip finish;

e, transparent, light green glass with prescription lip finish;

f, transparent, colorless glass with sloping collar-neck finish above a single narrow ring;

g, transparent, colorless glass with rounded collar-neck finish with a single-rounded ring below;

$\mathrm{h}$, transparent, aqua glass with plain lip neck finish with a single beveled ring below;

$i$, semitransparent, green glass with applied ring (possible beverage bottle). 


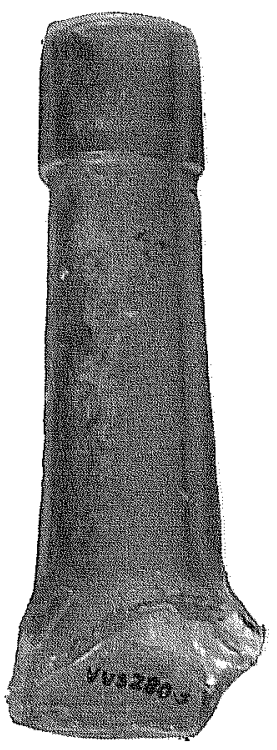

a

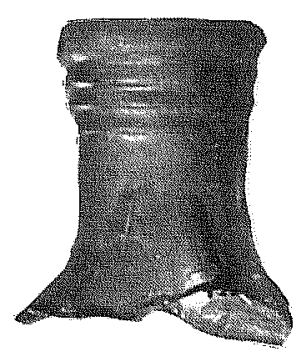

d

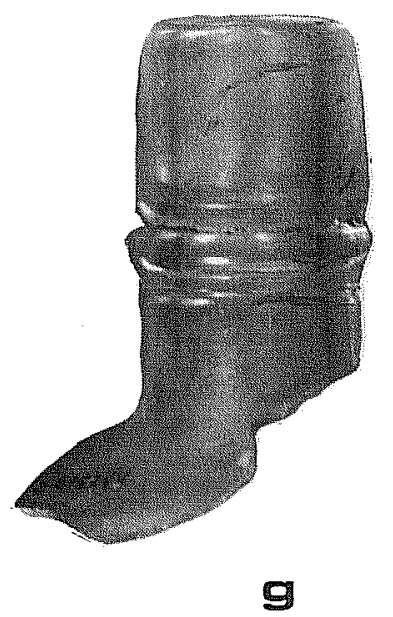

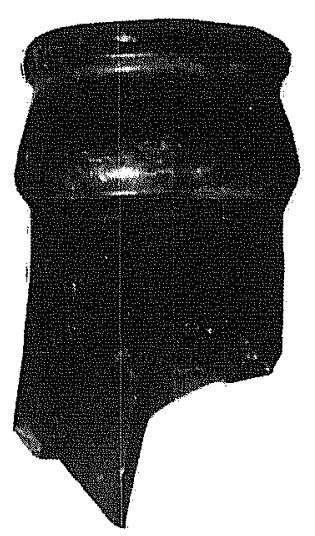

$b$

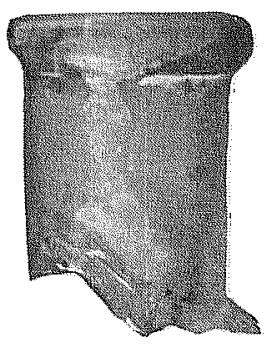

e
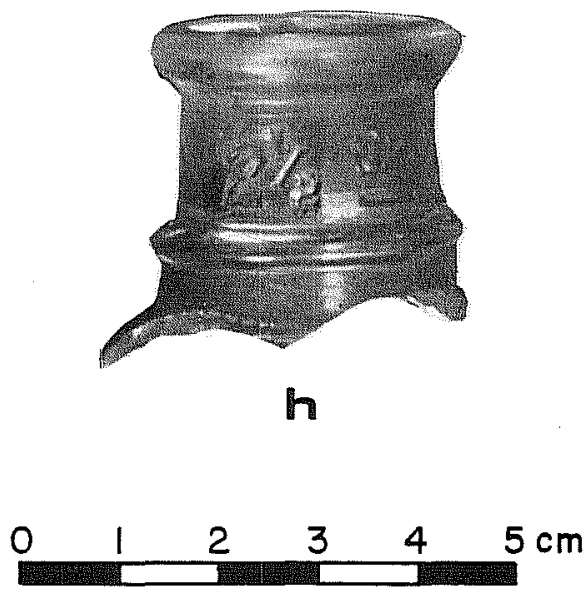
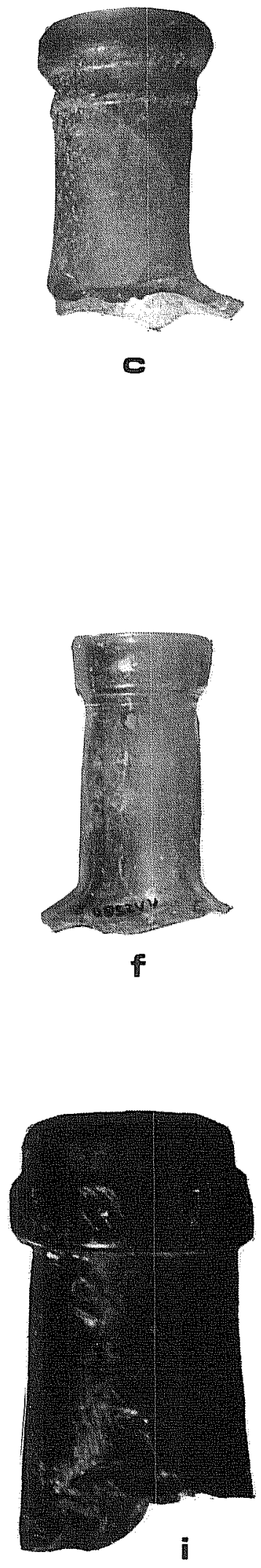


\section{MISCELLANEOUS ARTIFACTS}

Not all artifacts can be classified by the material used to make the item. The intended purpose or use for a particular item, in some cases, provides the most useful classification. Artifacts (Fig. 30,a-j) intended for recreation by adults and children reflect the basic attitudes, morals, and pastimes of their former owners. The original cost of these items directly reflects the social class or status of the individual as well. 


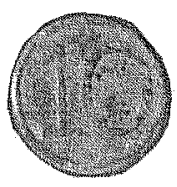

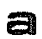

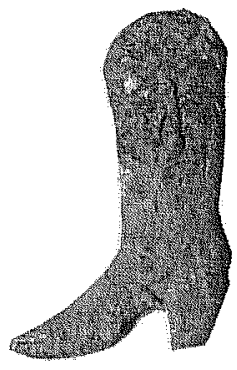

d

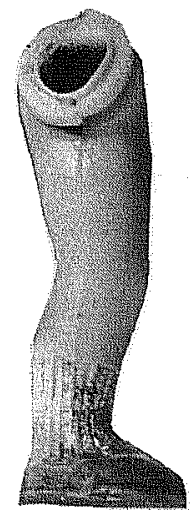

g

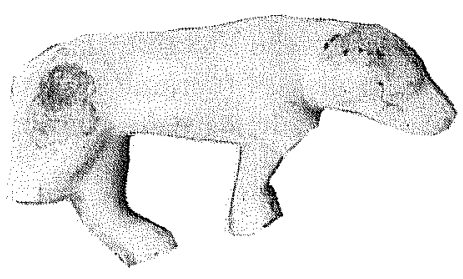

b

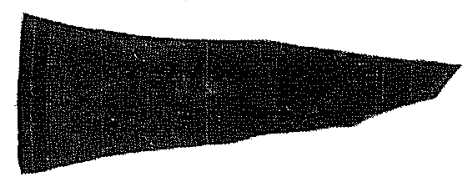

e

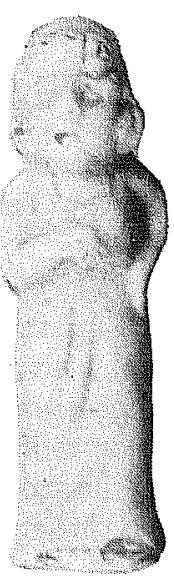

8

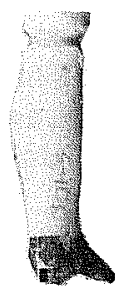

f

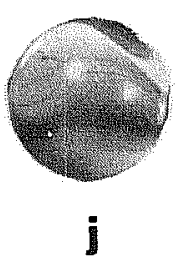

Figure 30. Miscellaneous Artifacts. a, play money from a child's game (n.d.); b, porcelain dog (ca. late 19th century); c, porcelain doll(?) (ca. late 19th century); d, miniature plastic cowboy boot (n.d.); e, record fragment (ca. mid-20th century); f,g, porcelain doll leg (ca. late 19th century); h, pool cue chalk (n.d.); i, miniature plastic dog (n.d.); j, cat's eye marble (mid-20th century). 


\section{SUMMARY AND RECOMMENDATIONS}

The artifact analysis for the recovered materials from the Vista Verde South survey relied on previously established local chronologic sequences for various artifact classes (ceramics, glass, metal). Sample size and questionable stratigraphic contexts limited the analysis to a comprehensive descriptive study. In all, 1631 items were recovered by this survey (Table 2).

The majority of these artifacts date to the late 19th to early 20th centuries and are consistent with others that have been found in various San Antonio historic sites (Clark 1974; Ivey 1978a, 1978b; Fox, Valdez, and Bobbitt 1978). In general terms, these artifacts reflect behaviors normally associated with residential or domestic activities. Artifact concentrations on NCB 276, NCB 280, and NCB 303 would seem to indicate that some residents dumped or burned domestic rubbish behind their residences along property and fence lines. No firm data were obtained to establish the method of trash disposal for the entire area. This may be due to the widespread subsurface disturbances throughout the project area or may be a matter of sampling.

Excavation of identified artifact scatters at some future date is not considered to be warranted or feasible. Project development, with its associated subsurface disturbances, has greatly reduced the likelihood of finding intact archaeological features or deposits. In this context, excavation at public expense cannot be justified in view of the potential for data recovery.

The artifact concentrations identified during the survey consisted of deposits sandwiched between sterile soil zones; no garbage pits or trash piles were located. A nagging question is how, and where, did these residents dispose of their rubbish, as these scatters present a fragmentary picture of late 19th-century life within a well-established middle class neighborhood.

This survey has pointed out the necessity for future research projects in San Antonio to address the problem of trash disposal practices prior to systematic city garbage pickup which began sometime around the turn of this century. There is a fundamental need to establish just what the attitudes towards trash disposal were among 19th-century (and earlier) San Antonio residents. It can be assumed that different ethnic and racial backgrounds would produce different attitudes towards domestic trash disposal which would be reflected in the locations and contents of garbage disposal areas. The need for research in this area has been pointed out before (Fox and Livingston 1979:73). Some preliminary work along these lines in 18th-century Spanish colonial sites in San Antonio has already been done (Fox, Bass, and Hester 1976; Fox 1977). Until attention is given to this problem by forming research questions with testable hypotheses, historical archaeology will continue to record a fragmentary picture.

This survey has also pointed out the need for the City of San Antonio to establish priorities for dealing with irreplacable historic and prehistoric resources along with the existing (and future) urban planning programs. It has been estimated that upwards of $60 \%$ of all historic and prehistoric sites in Texas have been badly damaged by urban and industrial expansion, strip mining, agricultural activities, construction of highways, pipelines, utility lines, and vandalism (Texas Historical Commission 1973:62). The Texas Historical Commission has estimated that between 5000-7000 prehistoric and historic properties are damaged or destroyed each year (D. Fox 1983:368). A more timely archaeological survey of the Vista Verde South properties could have saved valuable information that is now lost. 


\section{REFERENCES CITED}

Anonymous

1911- The Blue Book. Privately published.

1912

Appler, J. A.

1877 City Directory for the City of San Antonio. Privately published.

1879- City Directory for the City of San Antonio. Privately published.

1880

1894 City Directory for the City of San Antonio. Privately published.

Barnes, C. E.

1910 Combats and Conquests of Immortal Heroes. Guessaz and Ferlet Company, San Antonio.

Bexar County

Bexar County Deed Records (BCDR)

Volumes 11, 12, 19, and 127. Originals and microfilm in the Bexar County Courthouse, San Antonio, Texas.

Blumstein, L.

1966 Bottle Rush USA. Old Time Bottle Publishing Company, Salem, Oregon.

Bobbitt, L. O.

1981 Historical Narrative. In Vista Verde South: Historical and Architectural Assessment, by DeLaraAlmond Architects, Inc., and L. O. Bobbitt:5-31. Prepared for the City of San Antonio, April 15, 1981.

Bowen, J.

1857 Letter from John Bowen to Samuel A. Maverick, dated November 12, 1857.

Breig and Associate

1981 Survey of Historic Structures/Vista Verde South. Prepared for the San Antonio Conservation Society.

City of San Antonio

City Council Minutes $(C C M)$

1889 Volume H:557, December 16. City Clerk's Office, City Hall, San Antonio, Texas.

1889 San Antonio City Ordinance JH-443, Bawdy House Legislation. City Clerk's Office, City Hall, San Antonio, Texas. 
City Council Minutes (continued)

1983 City Ordinance 57031. Authorization for the Center for Archaeological Research, The University of Texas at San Antonio to survey the Vista Verde South project area.

Clark, J. W.

1974 Preliminary Archaeological Investigations at Wulff House, San Antonio, Texas. Office of the State Archeologist, Texas Historical Commission, Special Report 14.

Corner, W.

1890 San Antonio de Bexar. Bainbridge and Corner Publishers, San Antonio, Texas.

Davenport, $\mathbf{R}$.

1978 The District: Where Vice was Virtue. The Magazine of San Antonio 2(1):50-55.

Davis, E. M. and J. E. Corbin

1967 Archeological Investigations at Washington-on-the Brazos State Park in 1966. State Building Commission Archeological Program, Report 5.

DeLara-Almond Architects, Inc.

1981 Vista Verde South Survey Project: Area Survey. San Antonio, Texas.

DeLara-Almond, Architects, Inc., and L. O. Bobbitt

1981 Vista Verde South: Historical and Architectural Assessment. Prepared for the City of San Antonio, April 15, 1981.

Eaton, J. D.

1980 Excavations at the Alamo Shrine (Mission San Antonio de Valero). Center for Archaeological Research, The University of Texas at San Antonio, Special Report 10.

Ferraro, P. and B. Ferraro

1961 A Bottle Collectors Guide. Western Printing and Publishing, Sparks, Nevada.

Fisher, C. S.

1976 The Urban Experience. Harcourt Brace Jovanovich Publishers, New York.

Fox, A. A.

1977 The Archaeology and History of the Spanish Governor's Palace Park. Center for Archaeological Research, The University of Texas at San Antonio, Archaeological Survey Report 31.

1978 Archaeological Investigations of Portions of the San Pedro and Alazan Acequias in San Antonio, Texas. Center for Archaeological Research, The University of Texas at San Antonio, Archaeological Survey Report 49. 
Fox, A. A. (continued)

1981 Test Excavations at Mission San Francisco de la Espada. Centerfor Archaeological Research, The University of Texas at San Antonio, Archaeological Survey Report 108.

1983a Archaeological Survey of the Vista Verde South Project: A Preliminary Report. Center for Archaeological Research, The University of Texas at San Antonio, Letter R'eport, June 1983.

1983b Archaeological Survey and Testing of the Vista Verde South Project: Phase II. A Preliminary Report. Center for Archaeological Research, The University of Texas at San Antonio, Letter Report, July 1983.

Fox, A. A., F. Bass, Jr., and T. R. Hester

1976 The Archaeology and History of Alamo Plaza. Center for Archaeological Research, The University of Texas at San Antonio, Archaeological Survey Report 16.

Fox, A. A. and T. R. Hester

1976 Archaeological Test Excavations at Mission San Francisco de la Espada. Center for Archaeological Research, The University of Texas at San Antonio, Archaeological Survey Report 22.

Fox, A. A. and J. E. Ivey

n.d. Archaeological and Historical Investigations at Alamo Historical Park, San Antonio, Texas. Center for Archaeological Research, The University of Texas at San Antonio, Archaeological Survey Report 120 (in preparation).

Fox, A. A. and K. Livingston

1979 Historical, Architectural and Archaeological Investigations at the Steiner-Schob Complex, Victoria County, Texas. Center for Archaeological Research, The University of Texas at San Antonio, Archaeological Survey Report 52.

Fox, D. E.

1979 The Lithic Artifacts of Indians at the Spanish Colonial Missions, San Antonio, Texas. Center for Archaeological Research, The University of Texas at San Antonio, Special Report 8.

1983 Traces of Texas History: Archeological Evidence of the Past 450 Years. Corona Publishing Company, San Antonio, Texas.

Fox, D. E., F. Valdez, Jr., and L. O. Bobbitt

1978 An Archaeological Assessment of the Dolores Aldrete House Property, San Antonio, Texas. Center for Archaeological Research, The University of Texas at San Antonio, Archaeological Survey Report 58.

Fox, L.

1983 Letter from L. Wall (Advisory Council on Historic Preservation) to L. Fox (San Antonio City Manager), February 23, 1983. 
Freeman, M. D. and W. B. Fawcett, Jr.

1980 The Antebellum Period in the Stephen F. Austin Colony: Historical and Archeological Research in the Palmetto Bend Reservoir Area, Jackson County, Texas. Part I: The Sutherland Plantation and the Alabama Settlement: A Study in Cluster Migration (by Freeman), Part II: Archeological Investigations at Historic Sites (by W. B. Fawcett, Jr.). Texas Archeological Survey, The University of Texas at Austin, Research Report 70, Palmetto Bend Reservoir Series 5.

Giraud, F.

1849 Map entitled Plat of Lands West of San Pedro Creek, 1849. Daughters of the Republic of Texas Research Library, The Alamo, San Antonio, Texas.

Godden, G. A.

1964 Encyclopaedia of British Pottery and Porcelain Marks. Bonanza Books, New York.

1967 An Illustrated Encyclopaedia of British Pottery and Porcelain. Crown Publishers, New York.

Hafernik, D. and A. A. Fox

1984 Archaeological Testing of Proposed Sewer Line Location at Mission San José. Center for Archaeological Research, The University of Texas at San Antonio, Archaeological Survey Report 138.

Hendricks, B.

1980 San Antonio as Sin City, Cowboys and Military Enjoy Fleshy Delights. The News August 8.

Herrington, $\mathrm{L}$.

1982 Letter from the Texas Historical Commission (L. Herrington) to the San Antonio Historic Preservation Officer (P. Osborne), August 12, 1982.

Humphrey, D. C.

1983 Prostitution and Public Policy in Austin Texas 1870-1915. Southwestern Historical Quarterly LXXXVI(4):474-516.

Ing, J. D.

1976 Fort Lipantitlan State Historic Site, Nueces County, Texas, Archeological Testing - 1974. Texas Parks and Wildlife Department, Parks Division, Historic Sites and Restoration Branch, Archeological Report 16.

Israel, F. L., editor

18971897 Sears Roebuck Catalogue. Reprinted in 1968 by Chelsea House Publishers, New York.

Ivey, J. E.

1978a Archaeological Investigations at the Gresser House (41 BX 369), San Antonio, Texas. Center for Archaeological Research, The University of Texas at San Antonio, Archaeological Survey Report 60. 
Ivey, J. E. (continued)

1978b Archaeological Investigations at the Mayer House (41 BX 326), San Antonio, Texas. Center for Archaeological Research, The University of Texas at San Antonio, Archaeological Survey Report 59.

1983 Archaeological Testing at Rancho de las Cabras, 41 WN 30, Wilson County, Texas, Second Season. Center for Archaeological Research, The University of Texas at San Antonio, Archaeological Survey Report 121.

n.d. Archaeological Investigations at Mission Concepción and Mission Parkway, Part I: Excavations at Mission Concepción. Center for Archaeological Research, The University of Texas at San Antonio, Archaeological Survey Report 114 (in preparation).

Ivey, J. E. and A. A. Fox

1981 Archaeological Survey and Testing at Rancho de las Cabras, Wilson County, Texas. Center for Archaeological Research, The University of Texas at San Antonio, Archaeological Survey Report 104.

Jones, C. J. and A. A. Fox

1983 Archaeological Testing at Rancho de las Cabras, Wilson County, Texas, Third Season. Center for Archaeological Research, The University of Texas at San Antonio, Archaeological Survey Report 123.

Katz, P. R.

1978 Archaeological and Historical Investigations in the Arciniega Street Area, Downtown San Antonio, Texas. Center for Archaeological Research, The University of Texas at San Antonio, Archaeological Survey Report 61.

Kendrick, G.

1966 The Antique Bottle Collector. Edwards Brothers, Inc., Ann Arbor.

Koch, A.

1873 Bird's Eye View of the City of San Antonio, Bexar County, Texas, 1873. In the San Antonio Museum Collection. Published by R. H. Holland.

1886 Bird's Eye View of San Antonio, Bexar County, Texas, 1886, Looking Northeast. In the collection of the Randolph Blueprint Company, San Antonio, Texas.

Labadie, J. H.

1986 Additional Archaeological and Historical Studies for the Fairmount Hotel Project in San Antonio, Texas. Center for Archaeological Research, The University of Texas at San Antonio, Archaeological Survey Report 160.

Labadie, J. H., assembled by

1986 La Villita Earthworks: (41 BX 677): San Antonio, Texas. A Preliminary Report of Investigations of Mexican Siege Works at the Battle of the Alamo. Centerfor Archaeological Research, The University of Texas at San Antonio, Archaeological Survey Report 159. 
Lorrain, D.

1968 An Archaeologist's Guide to Nineteenth Century American Glass. Historical Archaeology 2:3544.

Mankowitz, W. and R. G. Haggar

1975 The Concise Encyclopedia of English Pottery and Porcelain. Hawthorn Books, Inc., New York.

Mayer, A. J.

1976 San Antonio, Frontier Entrepot. Ph.D. dissertation, The University of Texas at Austin.

Miller, G. L.

1980 Classification and Economic Scaling of 19 th Century Ceramics. Joumal of the Society of Historical Archaeology 14:1-40.

Miller, G. L. and C. Sullivan

1981 Machine-Made Glass Containers and the End of Production for Mouth-Blown Bottles. Parks Department, Research Bulletin 171. Canada.

Montgomery Ward and Co.

1895 Montgomery Ward \& Co., Catalogue and Buyer's Guide, No. 57, Spring and Summer 1895. Unabridged facsimile published in 1969. Dover Publications, Inc., New York.

Olds, D. L.

1967 The French Legation Kitchen. Prepared for the Daughters of the Republic of Texas by the Texas Archeological Research Laboratory, The University of Texas at Austin.

O’Neill, Perez, Lance, and Larcade

1972 San Antonio Historic Survey, 1972. San Antonio City Planning Department, Community Renewal Program, San Antonio, Texas.

Rathje, W. L. and M. B. Schiffer

1980 Archaeology. Harcourt Brace Jovanovich Publishers, New York.

Robinson, D. P.

1971 Antique Bottle Identification Made Easy. ATR Enterprises, Prescott, Arizona.

San Antonio Independent School District (SAISD)

1983 Fact Sheet, History of the Jose Antonio Navarro School, Downtown San Antonio.

Sanborn Map and Publishing Company, Ltd.

1904 Map of San Antonio, Texas. New York. 
Sears, Roebuck and Co.

19021902 Edition of the Sears, Roebuck Catalogue. Reprinted in 1969 by Bounty Books, Crown Publishers, Inc., New York.

Stephens, C.

1979 Dating and Collecting Ball Jars. The Antiques 1:30-32.

Taylor, A. J. and A. A. Fox

1985 Archaeological Survey and Testing at Rancho de las Cabras, Wilson County, Texas, Fifth Season. Center for Archaeological Research, The University of Texas at San Antonio, Archaeological Survey Report 144.

Texas Historical Commission

1973 Historic Preservation in Texas: The Comprehensive Statewide Historic Preservation of Texas. Vol. 1. Published jointly by the Texas Historical Commission and the Office of Archeology and Historic Preservation, United States Department of the Interior.

1979 The Texas Historical Commission Inventory Master File. On file at the Texas Historical Commission, Austin.

Tunnell, C. D. and J. R. Ambler

1967 Archeological Excavations at Presidio San Agustin de Ahumada. State Building Commission Archeology Program, Report 6.

United States Congressional Record

1906 Antiquities Act of 1906. PL 59-209; 34 Stat. 225; 16 U.S.C. 431-433.

1935 Historic Sites Act of 1935. PL 74-292; 49 Stat. 666; 16 U.S.C. 461-467.

1960 Reservoir Salvage Act of 1960. PL 86-523; 74 Stat. 220; 16 U.S.C. 469-469c.

1966 National Historic Preservation Act of 1966. PL 89-665; 80 Stat. 915; 16 U.S.C. 470.

1971 Executive Order 11593. 36 CFR 8921; 16 U.S.C. 470.

1974 Archeological and Historic Preservation Act of 1974. PL 93-291; 88 Stat. 174; 16 U.S.C. 469.

United States Department of Commerce, National Information Service

1978 Fort Vancouver, 1829-1860. A Historical Archaeological Investigation of the Goods Imported and Manufactured by the Hudson's Bay Company (Part 2). PB-283 100.

Wilson, R. L.

1981 Bottles on the Westem Frontier. Edited by Edward Staski. University of Arizona Press, Tucson. 


\section{APPENDIX}

\section{STRUCTURES IN THE VISTA VERDE SOUTH PROJECT AREA}

Photographs of the structures within the Vista Verde South project area that have been determined eligible for nomination to the National Register of Historic Places are provided in Figures 31- 40. Each photograph includes a map reference to Figure 14 to assist in locating the structure within the larger project area. All photographs were originally published in the DeLara-Almond Architects, Inc., and Bobbitt (1981) report. 

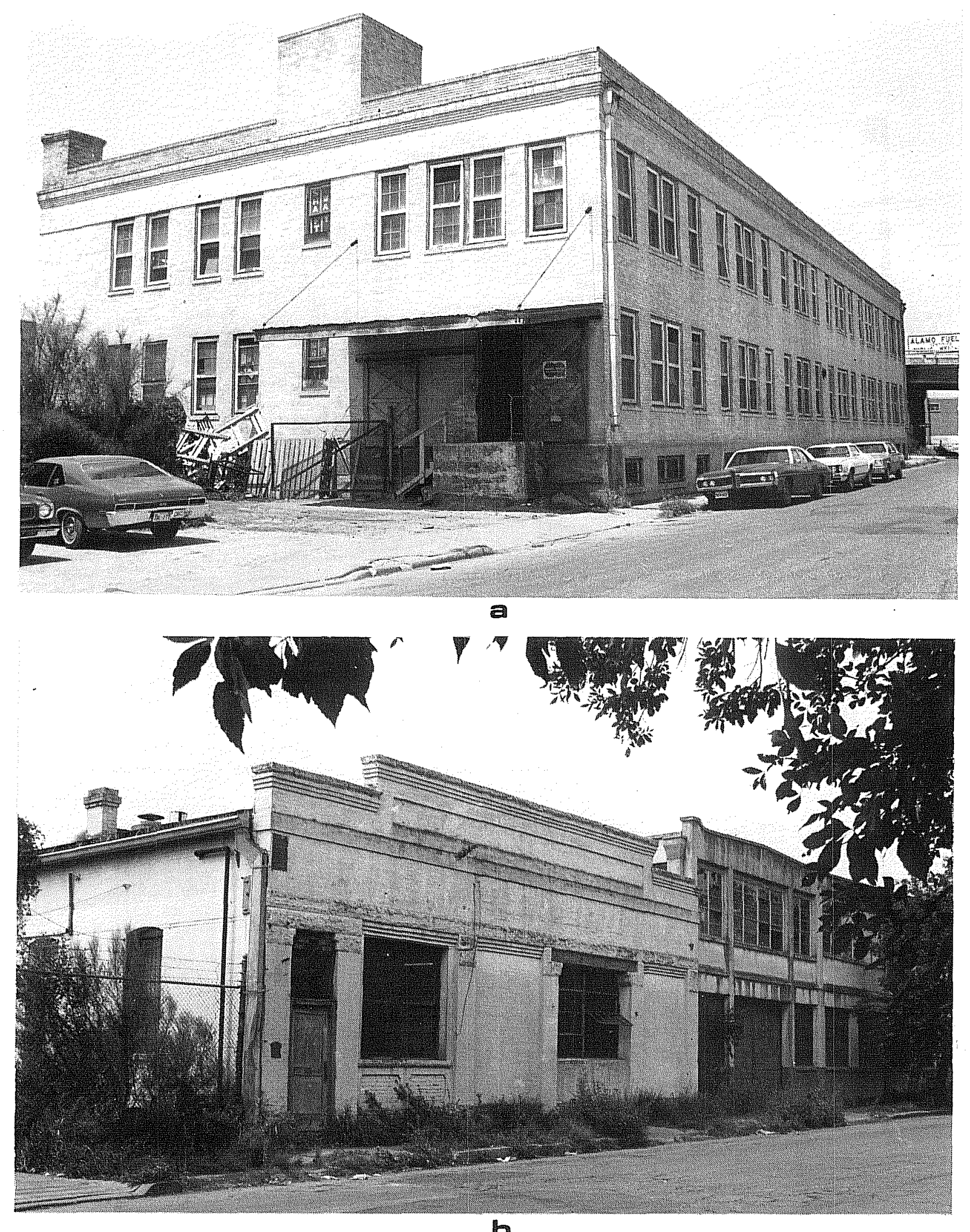

Figure 31. Structures at 602 Buena Vista Street and 301-315 South Frio Street. a, 602 Buena Vista Street, Map Reference A (Fig. 14), demolished with SHPO permission; b, 301-315 South Frio Street, Map Reference B (Fig. 14), demolished with SHPO permission. 

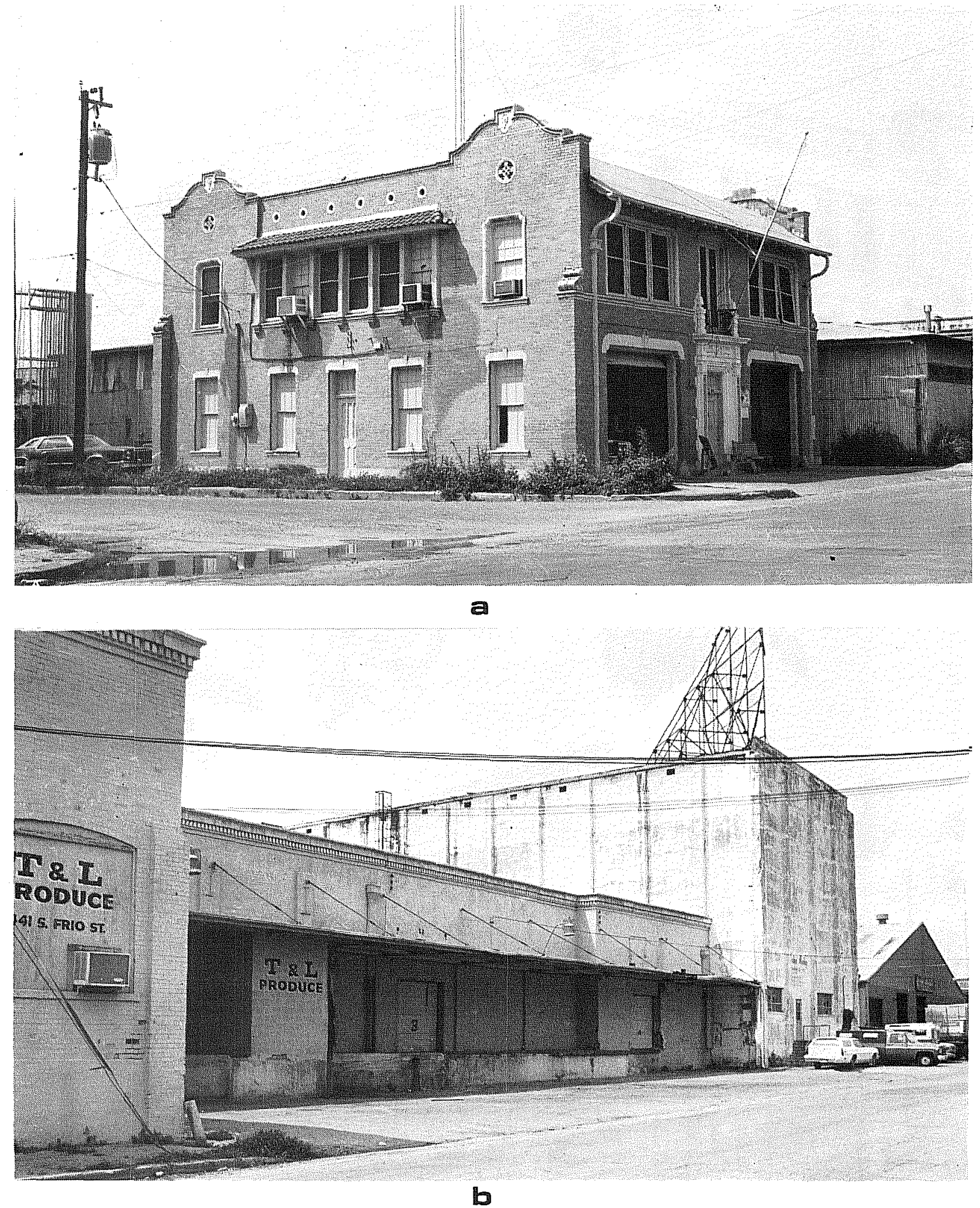

Figure 32. Structures at 323 South Frio Street and 427-441 South Frio Street. a, 323 South Frio Street, Map Reference C (Fig. 14), standing August 1, 1985; b, 427-441 South Frio Street, Map Reference D (Fig. 14), demolished with SHPO permission. 

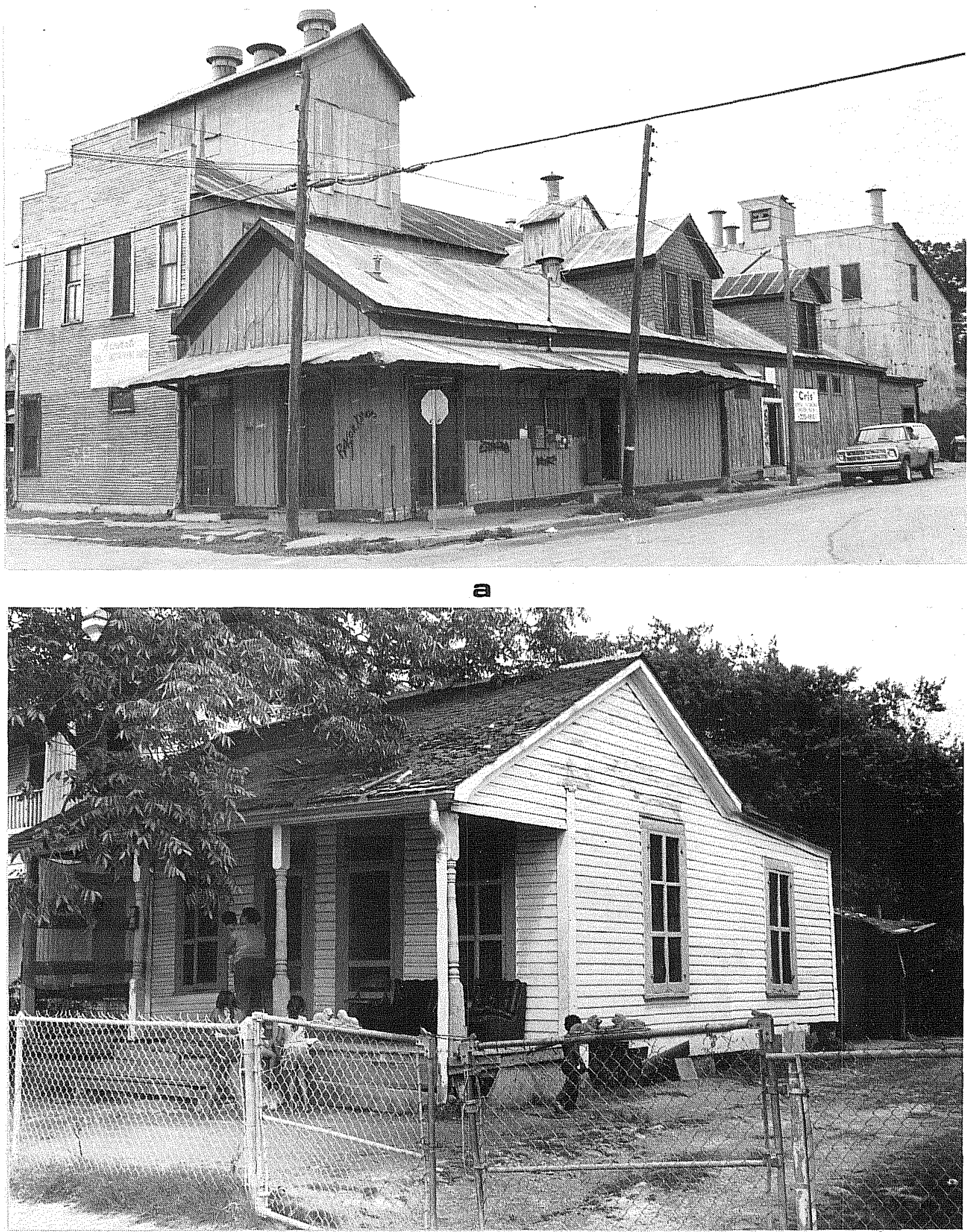

\section{b}

Figure 33. Structures at 701 South Leona Street and 514 South Frio Street. a, 701 South Leona Street, Map Reference G (Fig. 14), standing August 1, 1985; b, 514 South Frio Street, Map Reference H (Fig. 14), moved off original site. 


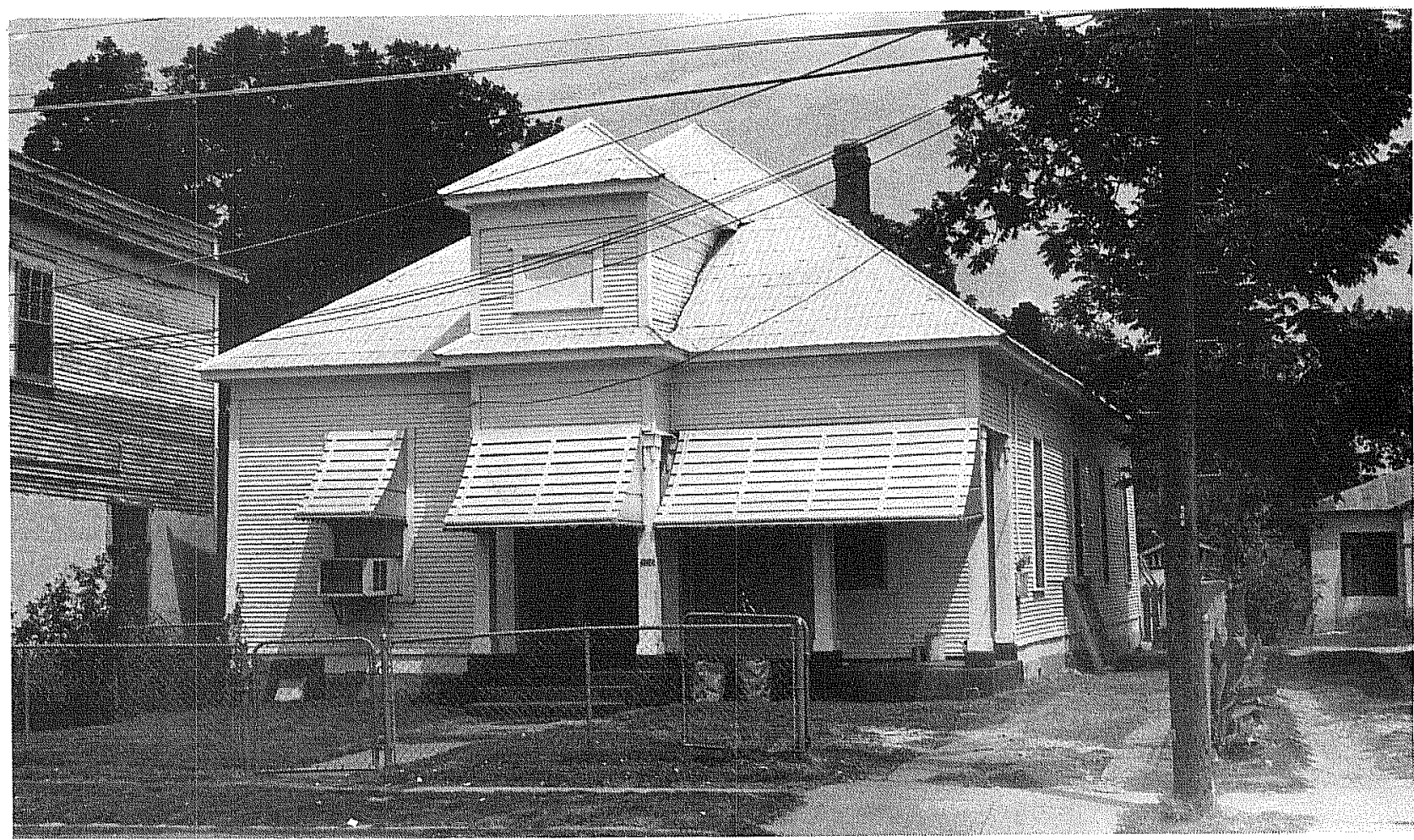

a

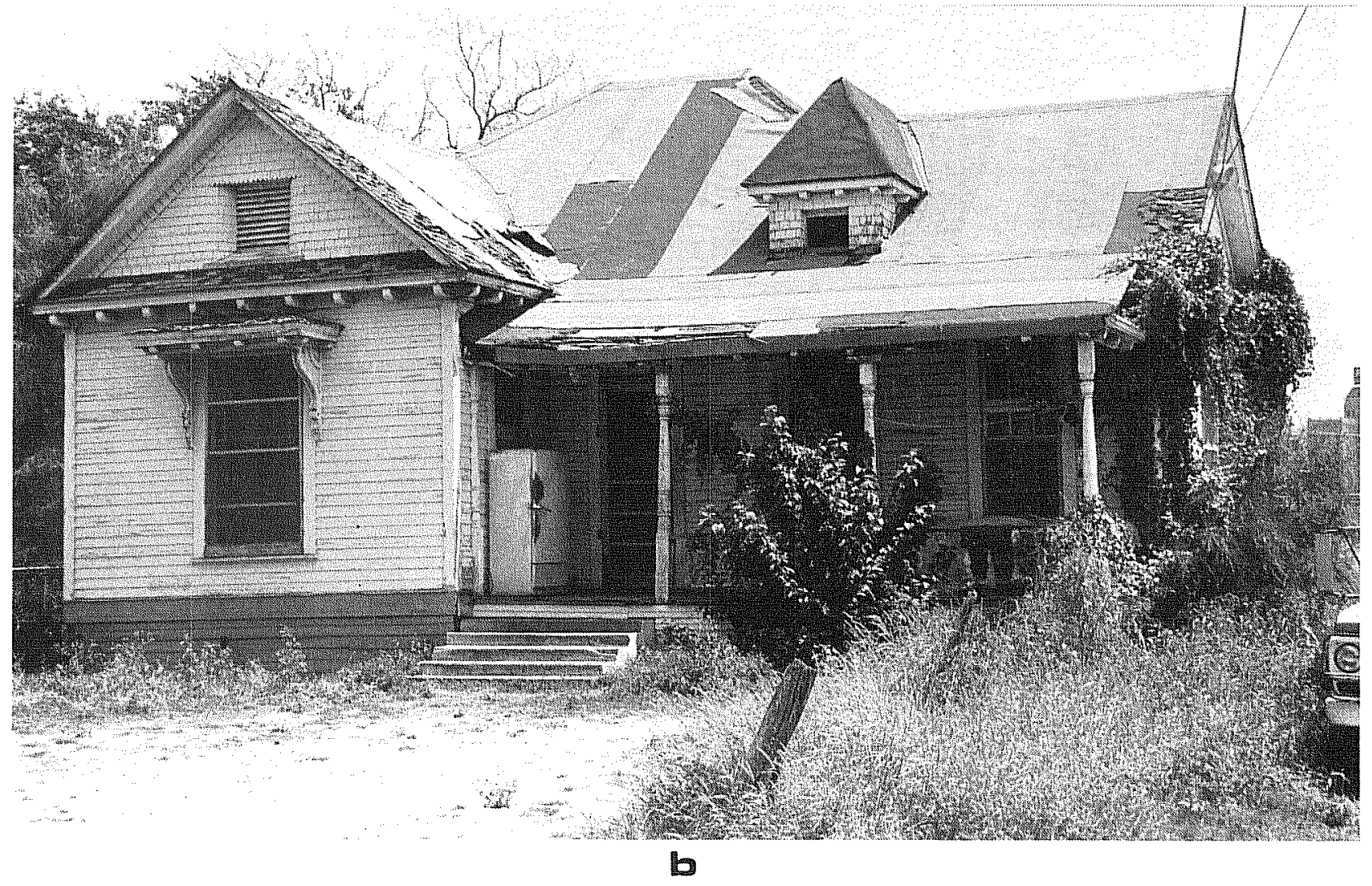

Figure 34. Structures at 508 South Frio Street and 208 South Leona Street. a, 508 South Frio Street, Map Reference I (Fig. 14), moved off original site; b, 208 South Leona Street, Map Reference J (Fig. 14), moved off original site. 


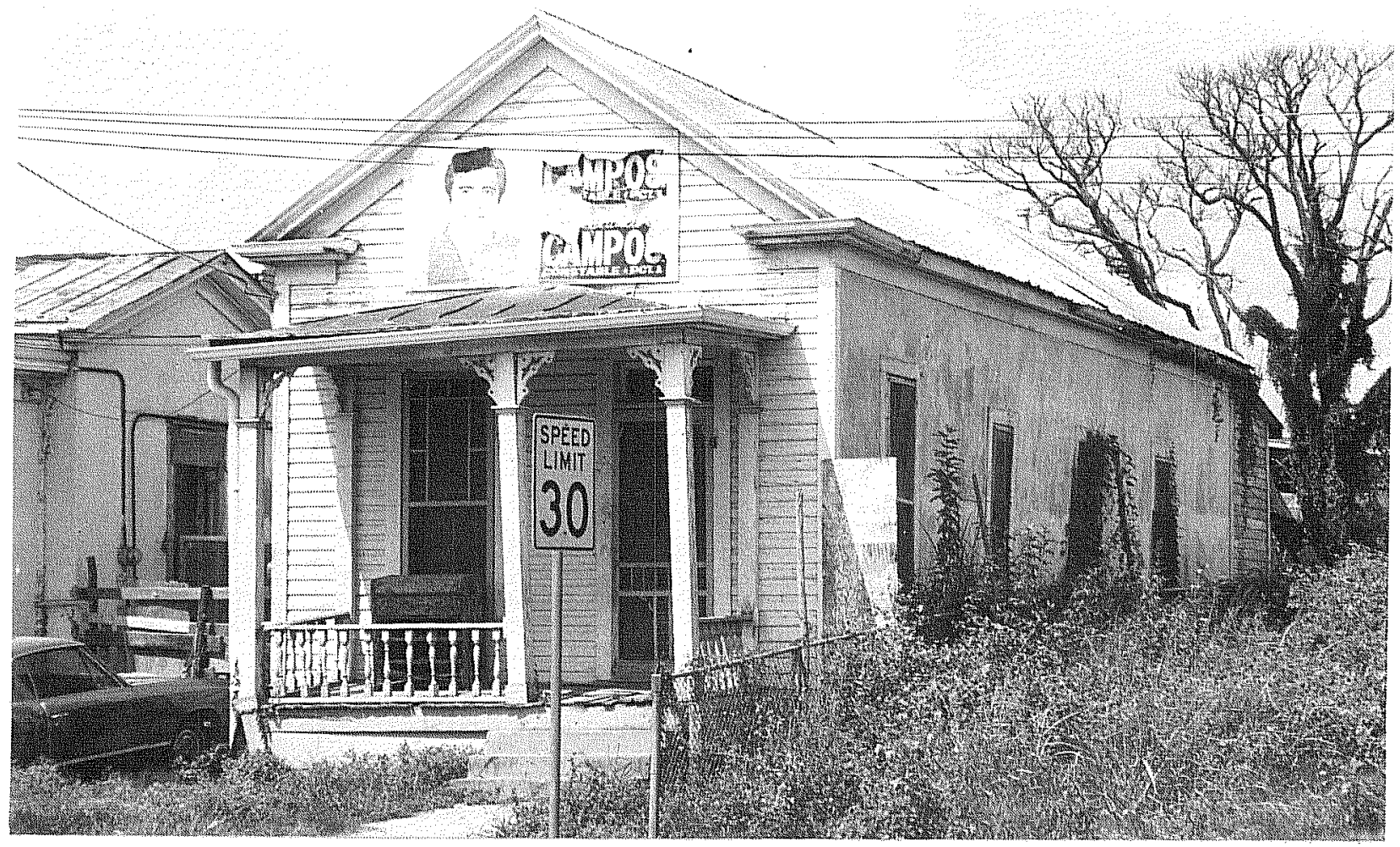

a

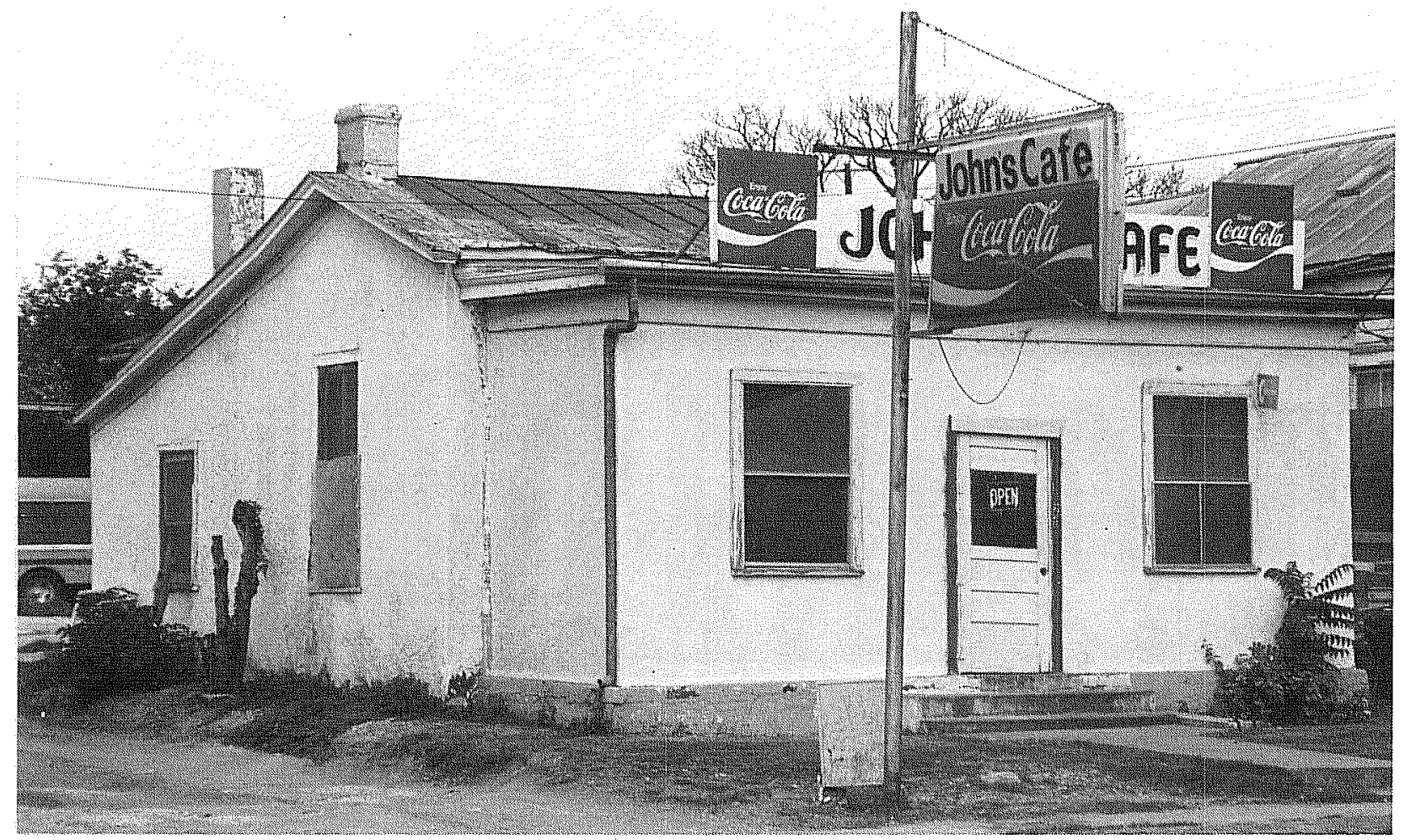

b

Figure 35. Structures at 209 South Pecos Street and 211 South Pecos Street. a, 209 South Pecos Street, Map Reference K (Fig. 14), moved off original site; b, 211 South Pecos Street, Map Reference L (Fig. 14), demolished with SHPO permission, 1983. 

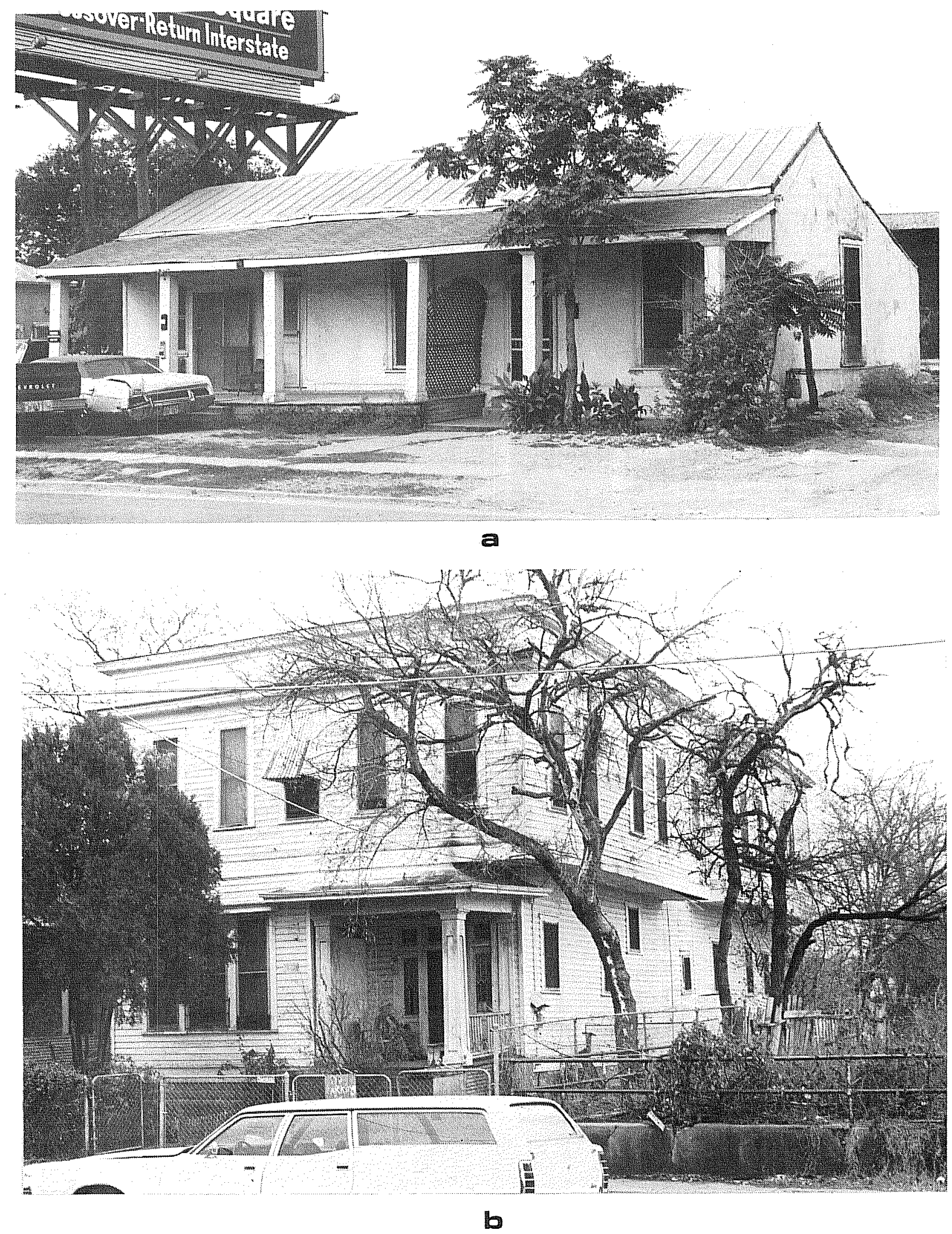

Figure 36. Structures at 213 South Pecos Street and 420 Matamoras Street. a, 213 South Pecos Street, Map Reference M (Fig. 14), demolished 1983 with no documentation; b, 420 Matamoras Street, Map Reference N (Fig. 14), demolished 1985 after documentation. 


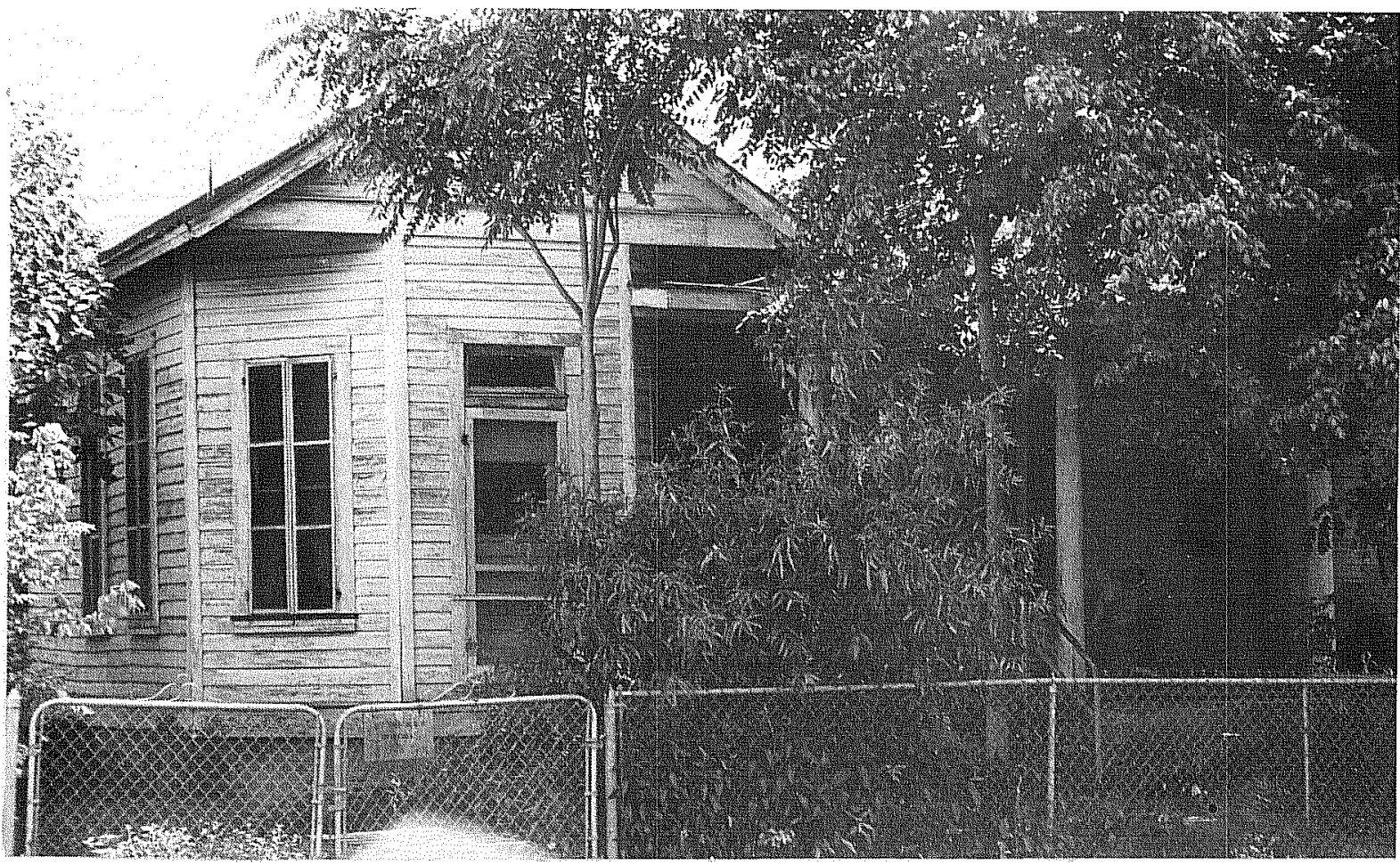

눙

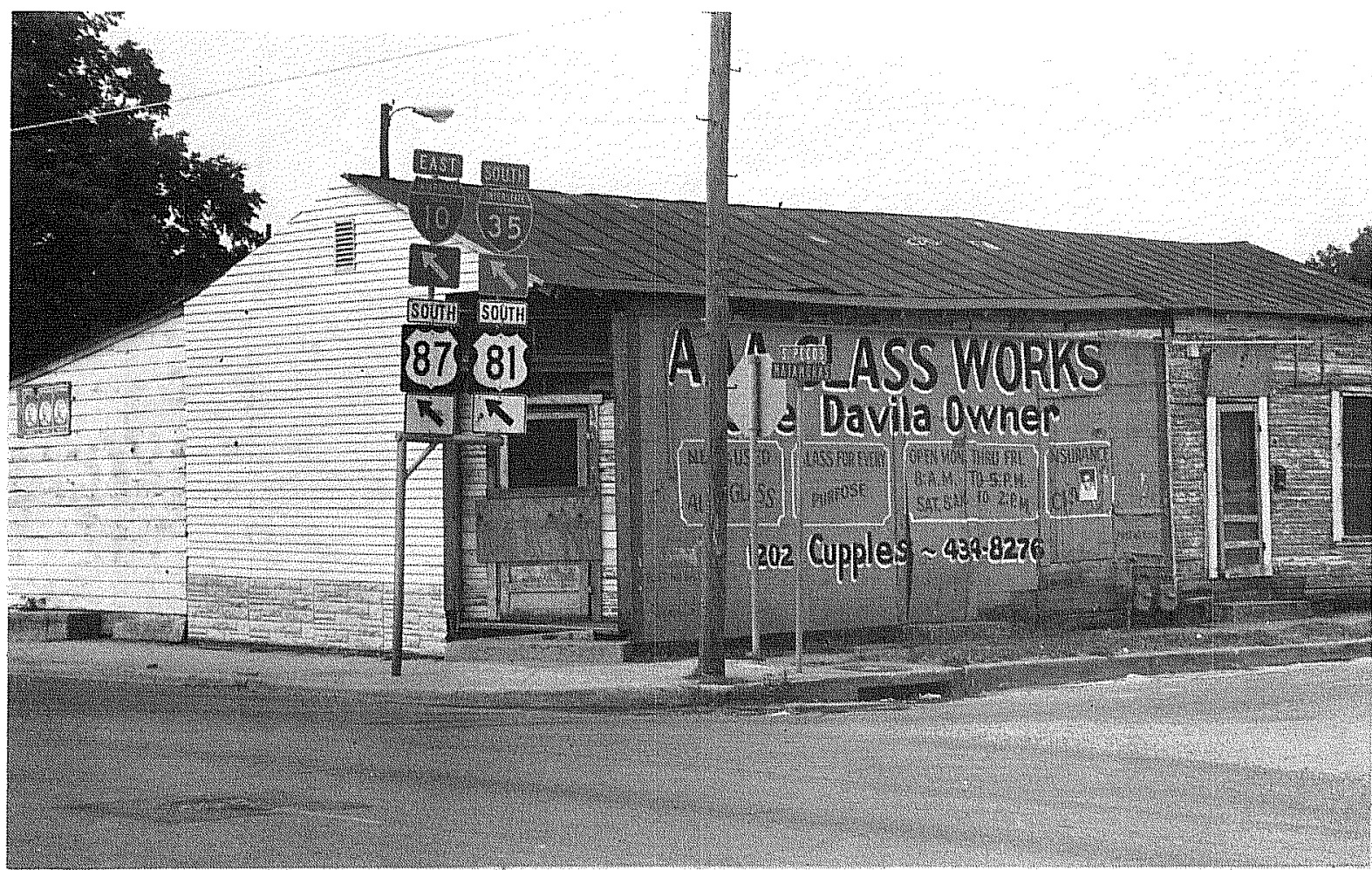

b

Figure 37. Structures at 416 Matamoras Street and 401 South Pecos Street. a, 416 Matamoras Street, Map Reference O (Fig. 14), demolished 1985 after documentation; b, 401 South Pecos Street, Map Reference P (Fig. 14), demolished 1985 after documentation (also listed as 402-1/2 South Pecos Street in DeLara-Almond Architects, Inc. [1981] report). 

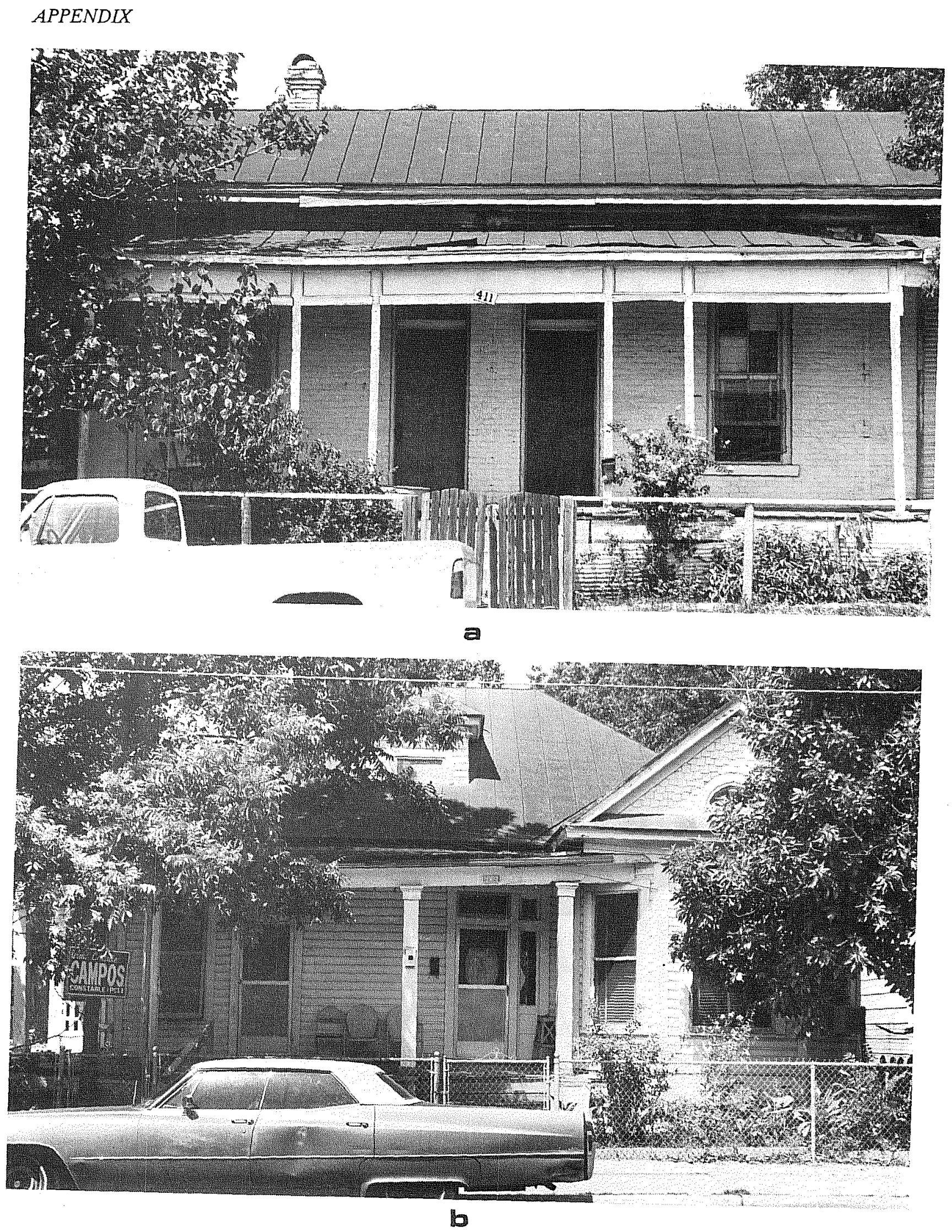

Figure 38. Structures at 411 South Pecos Street and 717 South Pecos Street. a, 411 South Pecos Street, Map
Reference Q (Fig. 14), demolished 1985 fter (Fig. 14), standing August 1, 1985. 

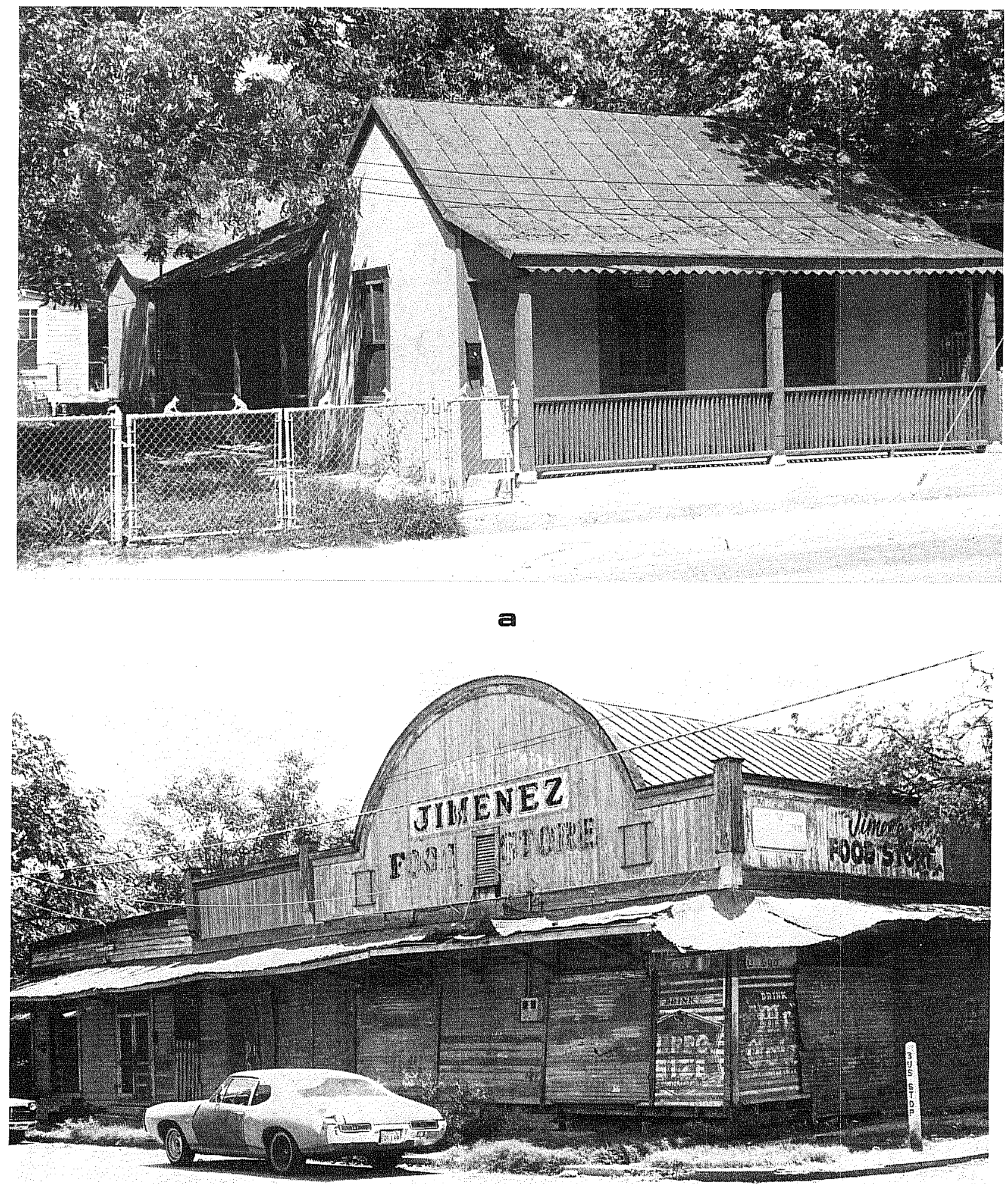

b

Figure 39. Structures at 721 South Pecos Street and 324 El Paso Street. a, 721 South Pecos Street, Map Reference S (Fig. 14), standing August 1, 1985; b, 324 El Paso Street, Map Reference T (Fig. 14), standing August 1, 1985. 


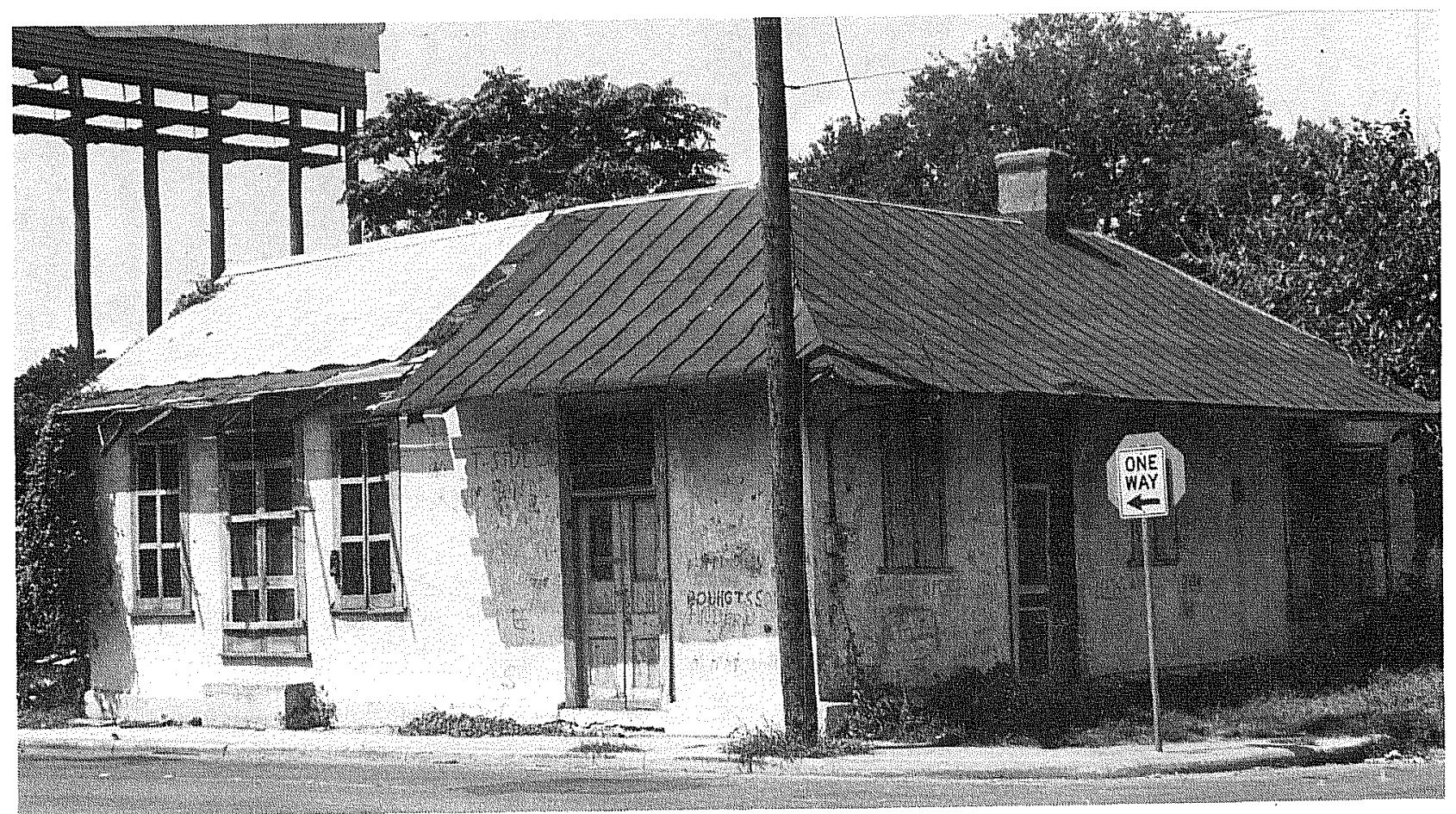

a
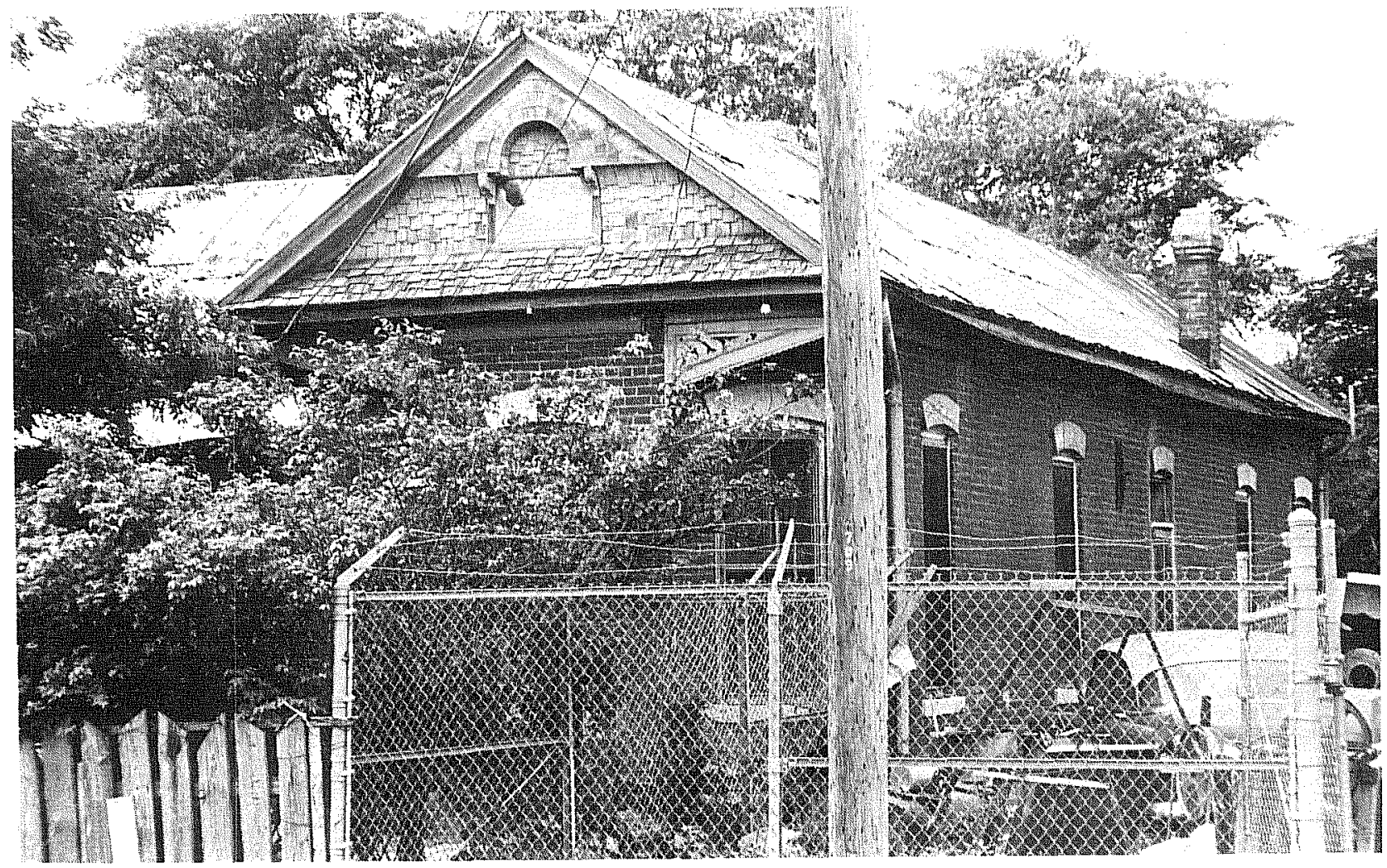
b

Figure 40. Structures at 801 South Pecos Street and 709 South Leona Street. a, 801 South Pecos Street, Map Reference U (Fig. 14), standing August 1, 1985; b, 709 South Leona Street, Map Reference F (Fig. 14), standing August 1, 1985. 